UNIVERSIDADE DE SÃO PAULO

ESCOLA DE COMUNICAÇÃO E ARTES

\title{
PROCESSOS CRIATIVOS DA DIREÇÃO CINEMATOGRÁFICA
}

CAROLINA GONÇALVES PINTO

SÃO PAULO

2015 
CAROLINA GONÇALVES PINTO

PROCESSOS CRIATIVOS DA DIREÇÃO

CINEMATOGRÁFICA

Dissertação apresentada ao Programa de Pós- Graduação Em Meios e Processos Audiovisuais,

Área de Concentração: Meios e Processos Audiovisuais, Linha de Pesquisa: Poéticas e Técnicas Escola de Comunicações e Artes da Universidade de São Paulo, como requisito para obtenção do título de Mestre no Programa Meios e Processos Audiovisuais

Orientador: Profa. Dra. Patrícia Moran Fernandes

\section{São Paulo}

2015 
Autorizo a reprodução e divulgação total ou parcial deste trabalho, por qualquer meio convencional ou eletrônico, para fins de estudo e pesquisa, desde que citada a fonte.

Catalogação na Publicação

Serviço de Biblioteca e Documentação

Escola de Comunicações e Artes da Universidade de São Paulo

Dados fornecidos pelo(a) autor(a)

Pinto, Carolina Gonçalves

Processos Criativos da direção cinematográfica / Carolina Gonçalves Pinto. -- São Paulo: C. G. Pinto, 2015.

$153 \mathrm{p}$.

Dissertação (Mestrado) - Programa de Pós-Graduação em Meios Processos Audiovisuais - Escola de Comunicações e Artes / Universidade de São Paulo.

Orientadora: Patrícia Moran

Bibliografia

1. processos criativos 2 . direção cinematográfica 3 .

diretores brasileiros 4. filme de ficção 5 . cinema
brasileiro I. Fernandes, Patrícia Moran II. Título.

CDD 21.ed. - 791.43 
Nome: PINTO, Carolina Gonçalves

Título: Processos Criativos da Direção Cinematográfica.

Aprovado em:

Banca Examinadora

Prof. Dr. Instituição:

Julgamento: Assinatura:

Prof. Dr. Instituição:

Julgamento: Assinatura:

Prof. Dr. Instituição:

Julgamento: Assinatura: 


\section{DEDICATÓRIA}

Aos cineastas que acompanhei como assistente de direção em seus filmes e que me inspiraram a observar seus processos e a querer escrever sobre eles. Aos cineastas Danièlle Huillet (in memorian) e Jean Marie Straub a quem passei longas tardes observando trabalharem na montagem de seus filmes, enquanto dividiam preciosas reflexões sobre o fazer cinematográfico. Ao meu querido avô Lito (in memorian) que me trouxe até aqui. 


\section{AGRADECIMENTOS}

À Capes/ CNPq, que através da concessão da bolsa de estudos, permitiu que me dedicasse a este trabalho de maneira satisfatória.

À Professora Patrícia Moran Fernandes, orientadora deste projeto, por sua dedicação, generosidade e confiança em todos os momentos. Pelos ensinamentos e trocas ao me acolher no PAE (Programa de Aperfeiçoamento de Ensino). Sua supervisão e companhia tornaram esta jornada possível e muito mais prazerosa.

Ao Professor Dr. Rubens Rewald e à Professora Dra. Maria Dora Genis Mourão por terem me incentivado a me lançar neste projeto.

À querida amiga e pesquisadora Kira dos Santos Pereira, por todo auxílio e companheirismo nesta jornada.

Às diretoras Lina Chamie e Suzana Amaral ao atenderem minha solicitação em participar deste projeto, recebendo-me com generosidade e entrega.

À minha família pela ajuda infinita, para que minha dedicação a este projeto fosse possível.

Ao meu companheiro Fernando Morgensztern Russo pelo apoio incondicional.

Aos meus filhos Martin e Alice, que me inspiram a cada dia. 


\section{RESUMO}

\section{Processos criativos da direção cinematográfica}

Esta pesquisa abordará o processo criativo no cinema de ficção e as transformações operadas ao longo de toda sua produção; do embrião da idéia à primeira forma do roteiro; do roteiro ao material filmado, montagens de imagem e som, até o filme pronto.

O foco desta pesquisa será o trabalho do diretor ao longo de todas as etapas e o caminho percorrido por suas tomadas de decisões, como o fio que conduz todo o processo até a cristalização na forma final do filme. Nesta pesquisa analisaremos o trabalho de outros chefes de equipe e técnicos do cinema, tratados aqui do ponto de vista cooperativo com suas interferências e colaborações, interpretadas dentro do processo de tomada de decisão pertinente ao trabalho do diretor/ realizador.

Pretende-se, para tanto, utilizar neste projeto de pesquisa os filmes A Via Láctea (2007) de Lina Chamie e Hotel Atlântico (2009) de Suzana Amaral, como objetos principais de estudo. Serão considerados como fonte de pesquisa: anotações e arquivos referentes à confecção do filme, entrevistas com as diretoras e os making ofs dos mesmos.

Neste projeto serão utilizados os conceitos apresentado por Paul Valéry e René Passeron no que diz respeito à Poética e o processo que envolve a criação artística. Também norteará este projeto A Teoria dos Cineastas de Jacques Aumont no que toca reflexões desenvolvidas pelos próprios cineastas sobre o ofício da realização.

Palavras Chave: processo criativo, direção cinematográfica, filme de ficção 


\section{ABSTRACT \\ Creative process of the filmmaking direction}

This study is about the filmmaking creative process of fictional movies and transformations occurred all long a film production; from its embryonic idea to its first screenplay, from the screenplay to its shootings, from the images and sounds to its first edition until the film is done.

We will focus on the craft of the film director, through the entire realization of a feature film. We'll track his process of taking decisions that leads the consolidation of a film project into its final format. In this research we'll investigate the craft of other heads of department and crewmembers under the perspective of their contributions and interferences on the director's work and creative process.

For that purpose, we'll to analyze the features films The Milky Way (2007) by Lina Chamie and Hotel Atlântico (2009) by Suzana Amaral. There will be considered manuscripts, rough drafts referring to these films productions, as well as, interview with the directors and making of material.

The concepts presented by Paul Valéry and René Passeron about Poetics and the process that embraces the art creation's process will guide our research. Also, we'll consider Jacques Aumont' Theories of Filmmakers and David Bordwell' On the History of Film Style concerning the reflections elaborated about they own craft.

Keywords: Creative Process; Film Direction; Fictional Movie 


\section{SUMÁRIO}

\section{INTRODUÇÃO}

\section{1 - O PROCESSO DE CRIAÇÃO DO DIRETOR CINEMATOGRÁFICO:}

1.1 - O Cinema e Suas Pequenas Mortes....................................................... 11

1.2 - Filmes e Cinemas................................................................................ 23

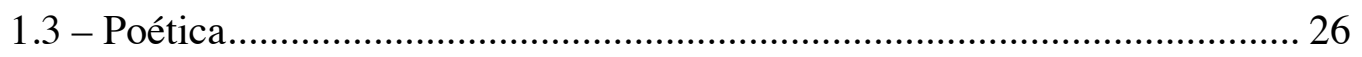

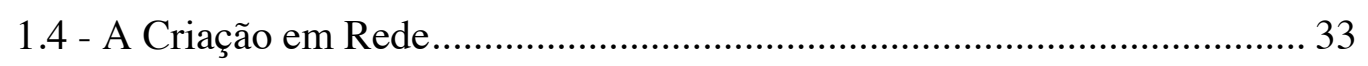

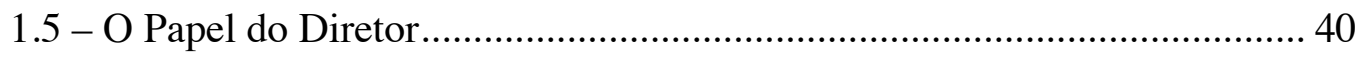

1.6 - As etapas de realização e imbricações de uma etapa em outra................... 43

1.7 - A Viabilização do Projeto...................................................................... 47

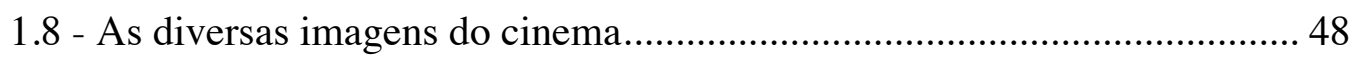

\section{2. - DOIS PROCESSOS CRIATIVOS:}

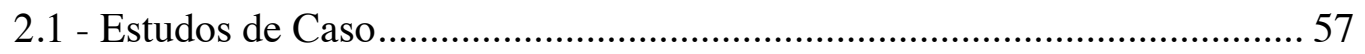

\section{2 - HOTEL ATLÂNTICO}

2.2.1 - A concepção do roteiro de Hotel Atlântico................................. 58

2.2.2 - A direção de atores e a decupagem em Hotel Atlântico................75

2.2.3 - Direção e montagem............................................................... 86

2.2.4 - Opções quanto à trilha sonora do filme...................................... 91 


\section{3 - A VIA LÁCTEA}

2.3.1 - A obra em aberto 103

2.3.2 - Estratégias de filmagem. 118

2.3.3 - A direção de atores e a não utilização de métodos de atuação...132

4. - REFERÊNCIAS BIBLIOGRÁFICAS

5. - REFERÊNCIAS AUDIOVISUAIS 152

6. - REFERÊNCIAS TEATRAIS 154

7. - REFERÊNCIAS DA INTERNET 154

\section{INTRODUÇÃO}




\section{O PROCESSO DE CRIAÇÃO DO DIRETOR CINEMATOGRÁFICO}

"No ato criador, o artista passa da intenção à realização através de uma cadeia de reações totalmente subjetivas. Sua luta pela realização é uma série de esforços, sofrimentos, satisfações, recusas e decisões (...)”"1

\section{1 - O Cinema e Suas Pequenas Mortes}

Grande parte das análises fílmicas parte unicamente de seus produtos acabados, olha-se apenas para os filmes, sem levar em conta como foram feitos. Um filme é resultado de escolhas feitas por seus realizadores, com o aparato de uma equipe técnica, que o auxiliou com seus conhecimentos específicos, na concretização do que foi concebido por seu idealizador. Este produto que chamamos de filme, surge após um processo de trabalho que se desenrola em um intervalo de tempo, fruto de determinada época. Pretendemos, ao longo desta pesquisa, analisar um filme sob a ótica de seu processo de realização. E seu processo de realização como o resultado de um conjunto de fatores que o torna singular. Analisaremos a criação cinematográfica de ficção sob o prisma de algo que acontece, em geral, como uma criação em rede, devido à colaboração entre diversos criadores. No entanto, centraremos nossa análise no papel desempenhado pelo diretor cinematográfico, em como este deve conceituar o filme, agregar e selecionar elementos trazidos por cada membro da equipe ou elenco, ao

${ }^{1}$ DUCHAMP, Marcel. O Ato Criador, in A Nova Arte - Organização Gregory Battock - São Paulo, Editora Perspectiva, 1975, pg. 73 
imaginar o filme que deseja fazer. O diretor é uma das poucas figuras presentes do início ao fim da realização de uma obra. Juntamente com o produtor, é um dos poucos que acompanha este processo por inteiro. Os demais colaboradores membros da equipe - roteiristas, montadores, diretores de arte e fotografia, entre outros - aparecem em momentos específicos, pois esta é a natureza de seus trabalhos.

Utilizaremos, para tratar de tal tema, os filmes A Via Láctea ${ }^{2}$ (2007) de Lina Chamie e Hotel Atlântico ${ }^{3}$ (2009) de Suzana Amaral, obras as quais pudemos acompanhar o processo de realização de perto, como assistente de direção. Buscamos esboçar algumas reflexões sobre estes processos de criação cinematográfica, com o intuito de contribuir para as discussões acerca do processo de criação cinematográfica contemporânea no Brasil.

A elaboração de uma obra de ficção compreende diversas transformações, sendo cada etapa deste processo muito diferente uma da outra no que diz respeito à natureza do trabalho de criação executado em cada uma delas. As questões com as quais o diretor cinematográfico deve lidar, o embate que trava para transformar o filme sonhado em filme real e até os colaboradores que terá em cada uma das etapas, aparecem sob os mais diferentes aspectos, ao longo do processo de realização de um filme. O próprio filme, ou projeto, é um objeto, ou matéria, diferente em cada uma destas etapas: idéia, roteiro, película (ou imagem digital), sons, fragmentos de cenas em ordenação e finalmente o filme pronto, que só existe enquanto projeção.

"Duas mortes e três nascimentos. Meu filme nasce uma primeira vez na minha cabeça, morre no papel; é ressuscitado pelas pessoas vivas e objetos que eu emprego,

2 CHAMIE, Lina. A Via Láctea, São Paulo, Girafa Filmes, 2007

3 AMARAL, Suzana. Hotel Atlântico, São Paulo, Planifilmes, 2009 
que são mortos na película, mas que, colocados em uma certa ordem e projetados sobre uma tela, se reanimam como flores na água". ${ }^{4}$

Este aforismo de Robert Bresson aborda o processo cinematográfico a partir de sua condensação em formas predominantes, em cada uma das etapas do processo da realização cinematográfica. Um filme morre muitas vezes ao longo do processo de sua realização. Existe, como veremos adiante, um longo caminho a ser percorrido, entre o filme idealizado pelo diretor e aquele que é concretizado no final, como fruto do trabalho coletivo e que acontece no limiar entre o trabalho planificado e desdobramento do acaso.

Alguns diretores decantam da realização de suas obras, teorias pelas quais tentaram explicar, para si e para outros, pensamentos preceitos que pretendiam seguir enquanto lidavam com o ofício de realizar seus filmes. Jacques Aumont, em A Teoria dos Cineastas $^{5}$, coloca algumas destas teorias lado a lado, comparando-as e analisando de que maneira estas se relacionam à obra de cada diretor que as criou e em que momento de suas carreiras elas foram elaboradas. Utilizamo-nos de algumas delas, nesta pesquisa, como uma tentativa de aproximação do trabalho do diretor cinematográfico. Aumont, ao tratar do que escreveu Bresson, por exemplo, ressalta a importância do acaso para a obra deste diretor, mesmo que ele tenha cada detalhe de seu filme planejado de antemão. Aumont explica esta aparente contradição entre o planejado e a abertura ao acaso pela seguinte afirmação: "Para Bresson, a obra se faz realmente por si na medida em que ele a faz." ${ }^{6} \mathrm{E}$ cita um dos aforismos de Bresson, no

\footnotetext{
4 "Deux morts et trois naissances. Mon film naît une première fois dans ma tête, meurt sur papier; est ressuscite par les personnes vivantes et les objets réels que j'emploi, qui sont tués sur pellicule mais qui, placés dans un certain ordre et projetés sur un écran, se raniment comme des fleurs dans l'eau.” BRESSON, Robert. Notes sur le Cinématographe, Paris, Éditions Gallimard, 1988, 25, t.n.

5 AUMONT, Jacques. A Teoria dos Cineastas, Papirus, Campinas, 2004

6 Ibid., pg.. 52
} 
qual o diretor define este seu trabalho, que transcorre no limiar a projeção do que será o filme e o presente momento da realização: "Filmagem. Colocar-se em um estado de ignorância e de curiosidades extremas, e assim mesmo ver as coisas à frente. (Notes sur le Cinématographe, pg 24)."7

Ao considerarmos um filme, idealizado por um diretor, podemos imaginar que antes deste vir a existir, ele percorreu uma série de caminhos que o levaram ao formato final do filme. Muito antes da consolidação de todas as etapas de sua realização, estamos lidando com o desejo de artistas que puseram suas forças a serviço daquela obra, para que ela existisse. E o filme seria a soma de cada uma das decisões que o diretor tomou, ao imaginar como faria para realizá-lo.

Cada diretor irá lidar com um corpus de questões, pertinentes ao seu trabalho. Como ressalta David Bordwell em seu livro Sobre História do Estilo Cinematográfico ${ }^{8}$, os filmes são respostas a questões colocadas pelos próprios diretores, a si mesmos.

Andrei Tarkovski, no prefácio de Esculpir o Tempo ${ }^{9}$, coloca a seguinte afirmação a respeito do que significa, para ele, mesmo a realização de seus filmes: “(...) fazer um filme atrás do outro, encontrando soluções práticas para os problemas teóricos que surgem sempre que se faz um filme" ${ }^{10}$. Mais adiante ele explica como suas concepções artísticas se consolidaram à medida que filmava A Infância de Ivan (1966) e como, ao longo da feitura deste mesmo filme, o diretor passou por questionamentos que o levaram a idealizar seu outro filme, O Espelho (1979). Este pensamento nos dá a entender que para este diretor, um próximo filme nasce de questões as quais o autor julga ainda não ter alcançado uma resposta satisfatória em outros precedentes. Ou

\footnotetext{
7 AUMONT, Jacques. A Teoria dos Cineastas, Papirus, Campinas, 2004, pg. 52

8 BORDWELL, David. Sobre a História do Estilo Cinematográfico, Campinas, Papirus, 2013

9 TARKOVSKI, Andrei. Esculpir o Tempo, São Paulo, Martins Fontes, 1998

10 Ibid. pg.1
} 
mesmo, que as questões só puderam aparecer para o artista como uma reflexão a respeito de suas escolhas já realizadas, mas que permanecem como um material para ser explorado em uma obra subseqüente.

Lina Chamie, quando fala, em A Via Láctea, sobre a escolha pelo uso da câmera fixada a um steady $\operatorname{cam}^{11}$, com maior possibilidade na movimentação, opõem a seu filme precedente Tônica Dominante ${ }^{12}$ (2000), no qual, segundo a diretora, cada plano era rigorosamente planejado. Ao usar a câmera no steady cam, a diretora delega aos atores e ao operador câmera ajustes na movimentação durante a atuação, tomada após tomada. Sua opção faz com que equipe e elenco de uma cena tenham certa autonomia, mesmo ao seguir um desenho pré-estabelecido pela diretora, contribuindo assim, com o poder de atuação do acaso.

Certamente, não há uma única maneira de realizar filmes, os caminhos da criação cinematográfica não obedecem a um modelo. Não podemos inferir que todos os projetos de filmes sejam realizados por processos semelhantes. Consideramos que há realizações de filmes em que as etapas da realização não se sucedem da mesma maneira, ou mesmo, projetos nos quais a separação em etapas não ocorre. Não podemos sequer afirmar que existam especificidades que designem a criação cinematográfica. Cada filme possui uma maneira e tempo únicos de realização e a divisão em etapas vai ocorrer, ou não, de acordo com a necessidade do processo criativo da obra. A estrutura de produção de um filme será planejada e executada conforme as necessidades que surgirem em um determinado projeto.

11 Equipamento utilizado preso ao corpo do operado de câmera sobre o qual a câmera é fixada, permitindo-se a realização de tomadas com a câmera solta de um tripé, mas mantendo certa estabilidade 12 CHAMIE, Lina. Tônica Dominante, São Paulo, 2000 
A forma como um filme se concretiza está, de certo modo, condicionada à maneira como o diretor desta obra conduz sua realização. No entanto, ao longo da história do cinema, observou-se na grande maioria dos filmes realizados, etapas semelhantes da realização e uma série de procedimentos equivalentes adotados por seus realizadores e colaboradores ao longo destas etapas. Para facilitar um maior entendimento, por parte dos diversos profissionais envolvidos em sua feitura, convencionou-se a divisão deste processo na forma como conhecemos e que freqüentemente são seguidas nas produções de filmes de ficção.

O encadeamento destas etapas, presente na grande maioria dos filmes, bastante diferentes entre si, talhados por diretores oriundos das mais distantes realidades e culturas, nos faz refletir acerca deste modelo que se concretizou como um paradigma da realização de filmes de ficção. Inúmeros fatores contribuíram para que as etapas nas quais se divide a produção de um filme se estabelecessem de determinada maneira e fossem seguidas por uma grande maioria de realizadores. Aspectos da própria história do cinema podem ser elencados, como a formação da indústria norte americana; modelos de financiamento o qual estas obras adotam e que trarão suas influências sobre a organização operacional; a transmissão do conhecimento acumulado por realizadores e absorvidos por novas gerações; mas também uma certa organização interna que se estabelece para que a criação coletiva possa fluir. Todos estes fatores, que analisaremos adiante, aparecem como questões, tão logo iniciamos uma reflexão sobre o processo da criação cinematográfica e podem ser entendidos como parte de um movimento maior que diz respeito às poéticas empregadas em suas concretizações. $\mathrm{O}$ próprio fazer cinematográfico apela para esta organização. 
Existe uma forte tendência para que a realização de um filme seja bastante planificada, que seu processo de realização busque seguir um projeto previamente planejado e bastante estudado. Se por um lado, as etapas de realização são parâmetros para designar um momento em um processo, por outro, os acontecimentos e desdobramentos, pertinentes à feitura de um filme, não podem ser repetidos de um filme para o outro uma vez que o processo de criação de uma obra não se repete. A forma como cada filme é conduzido é também o resultado da relação que o realizador estabelece com sua maneira de criar, seu entendimento do que é a realização daquele filme em questão. Lina Chamie, como veremos adiante, adotou diferentes estratégias de filmagens para as diversas situações que compunham A Via Láctea. Suzana Amaral, como descrito mais a frente, cria sua decupagem após os atores definirem suas movimentações em cena.

O processo está implícito no resultado, mas se quisermos desmontar os caminhos do artista pelo qual um produto foi elaborado, devemos olhar para a forma como o diretor coloca em prática seu trabalho. "Em toda a prática criadora há fios condutores relacionados à produção de uma obra específica que, por sua vez, atam a obra daquele criador como um todo."13

Quando pensamos em uma obra de arte, em sua existência, devemos considerar, que antes mesmo da formulação da idéia de um filme, pode existir uma sensação ou uma forma de pensamento imaginativo do qual se decanta a idéia para se fazer um filme. São diversas as formas de colocar a engrenagem criativa em movimento, seja a partir de imagens, idéias ou sensações.

"Fellini (1986b, Pg. 139) Fala dessa sensação como um ente variável e mutante. É a suspeita ou a sombra de um filme, talvez mesmo um filme que ele não saiba fazer e

13 SALLES, Cecília A. Gesto inacabado. Processo de criação artística, São Paulo, Fapesp/Anabluni, 2004, $3^{\mathrm{a}}$ edição, 37 
que, ao surgir pela primeira vez, é uma nebulosa vaga e indefinida. O contato com ele tem lugar na imaginação, é um contato noturno. Pode ser, e é amistoso. Neste momento o filme possui todos os requisitos, parece que é tudo e ainda não é nada. É uma visão, um sentimento. Sua pureza é que o fascina." 14

Fellini ainda exemplifica como a passagem entre esta sensação descrita por ele como pura, para algo que possui uma forma não se dá sem esforço:

"Como poderia procurar com verossimilhança o momento em que se verificou um primeiro contato com o sentimento, ou melhor ainda, com o pressentimento, a antecipação daquilo que seria o teu filme? As raízes de onde nasceram Gelsomina, Zampaño, e sua história, pertencem a uma zona profunda e obscura, constelada de sentimentos de culpa, temores, forte nostalgia por uma moralidade mais compreendida, lástima por uma inocência traída. Não consigo falar e tudo que digo me parece desproporcionado e inútil. Confusamente me recordo que, andando de automóvel num passeio pelos campos próximos a Roma, vagabundeando, indolente e sem destino, pela primeira vez, entrevi os personagens, a atmosfera e o sentimento deste filme (1986 a, pg. 76)" 15

Talvez, um primeiro contato do artista com sua obra possa ser involuntário, mas todo movimento realizado a seguir é uma tentativa deste em concretizar esta obra que ele vislumbra. Normalmente, após este primeiro lampejo que desencadeia o processo de conceituação de um filme, a obra em andamento deve, em seguida, se condensar em uma escrita, utilizando, para tanto uma linguagem que obedece uma estrutura. É por esta razão que o roteiro, de um certo modo, pela metamorfose que ele opera, destrói esta forma imaginativa inicial que poderia ser feita de um filme.

Por sua vez, por maior que seja a precisão do roteiro, ele não consegue, necessariamente, dar conta da duração real da ação no momento da filmagem, com todos os elementos que esta abriga. Cada etapa dentro de um processo é engendrado em sua precedente e contém já o embrião daquela que irá sucedê-la. A todo instante, num

\footnotetext{
14 Ibid. pg.54

15 SALLES, Cecília A. Gesto inacabado. Processo de criação artística, São Paulo, Fapesp/Anabluni, 2004, $3^{\text {a }}$ edição, pg.55
} 
processo de criação cinematográfica, todo o processo é re-atualizado, à medida que novas camadas vão sendo adicionadas e novas nuances se criam.

Sidney Lumet, em seu livro Fazendo Filmes ${ }^{16}$ (2001), nos fala: uma vez tendo acabado as filmagens, o que se vê são roteiros jogados no lixo. Esta imagem, descrita por Lumet, revela que aquele mesmo roteiro que serviu como guia durante todo o período de filmagem, ao qual diretor, elenco e equipe sempre recorriam para solucionar dúvidas ou relembrar algo que parecia essencial para a realização de uma cena, uma vez este momento passado, se torna um objeto inútil. Não devemos levar ao pé da letra esta afirmação, uma vez que o roteiro pode ainda ser utilizado como um guia para a montagem ou, em alguns casos, adquirir uma vida independente, ao ser transformado em obra literária. E, nem sempre, devemos considerar o roteiro como uma etapa obrigatória. Para muitos diretores, o roteiro será confeccionado apenas para fins de formalização de um projeto, mas que nunca será usado como um guia das filmagens. Suzana Amaral elabora um roteiro que contém todo o pensamento do que deseja filmar, no entanto, ela não escreve os diálogos. São seus atores que sugerem, em ensaios prévios, as linhas que dirão em cena. Sendo assim, seu trabalho é selecionar entre estas sugestões, aquilo que serve ao filme. Se por um lado o roteiro funciona para esta diretora como um guia das situações a serem desenvolvidas, por outro, ela prefere deixar os diálogos como lacunas para que os atores as preencham durante o processo de elaboração das cenas, como será analisado adiante. São escolhas que cada diretor deve fazer durante seu trabalho. E as escolhas em uma etapa podem se refletir ao longo de todo o filme. Neste caso, sua determinação em não escrever os diálogos, deriva da forma como conduz a direção de atores

16 LUMET, Sidney. Fazendo Filmes, Rio de Janeiro, Rocco, 1998 
Um roteiro pode sugerir diversas imagens e como veremos adiante, a criação em rede comporta que cada membro dentro de uma equipe, contribua a partir de sua leitura pessoal de um mesmo texto. Já a imagem filmada tem como dimensão a sua concretude, ela pode, também ser interpretada de diversas maneiras, mas quando tratamos de imagens não abstratas, de seres e objetos, temos a presença destes no quadro, trata-se de um dado objetivo. Evidentemente, vemos se operar uma metamorfose quando passamos da forma escrita do roteiro para a forma filmada de uma cena, mas é impossível de se precisar todas as decisões que foram agregadas e outras descartadas para se chegar à operação destas passagens. Em A Via Láctea há uma cena em que Lina Chamie utilizou uma câmera lenta e o som deslocado em relação à imagem. O texto que ouvimos em off na voz de Marco Ricca, que interpreta Heitor $^{17}$ traduz o que vemos na imagem “...elas(as estrelas) vivem num outro tempo, o brilho de uma estrela demora anos-luz para chegar no nosso céu, quando a gente vê o brilho dela muitas vezes ela nem existe mais.... ${ }^{18}$. No roteiro há também uma indicação de que a cena será rodada em câmera lenta e o som será deslocado, mas a escrita não dá conta de colocar som e imagem em um único plano. É preciso que imagem e som existam gravados em suportes distintos e justapostos na montagem para que o objetivo da realizadora seja alcançado e crie o sentido desejado. Esta metamorfose só se torna possível fora do roteiro.

As etapas seguintes (casting, escolha de locações, elaboração do figurino), nas quais transformações e fixação se sucedem, acumulam em si as escolhas das etapas precedentes. Cada morte e ressurreição, como sugere o diretor Robert Bresson em Notas Sobre o Cinematógrafo ${ }^{19}$, não são, nada além, do que a metamorfose de um estado do

\footnotetext{
17 Protagonista de $A$ Via Láctea

18 ABIB, Aleksei e CHAMIE, Lina. A Via Láctea, São Paulo - Roteiro Cinematográfico, 2004

19 BRESSON, Robert. Notes sur le Cinématographe, Paris, Éditions Gallimard, 1988
} 
filme na sua etapa seguinte. No entanto, podemos pensar, que assumindo diferentes formas ao longo de sua feitura, trata-se de uma única obra em andamento, que abandona formas para se metamorfosear em seu estado seguinte, até chegar sua cópia final.

Em seu texto $O$ Pensamento $e$ o Movente $^{20}$, Henri Bergson evoca a impossibilidade da fragmentação de uma transformação em sua duração contínua; um filme estará sempre vinculado à sua concepção e os caminhos que esta percorre, seja qual for a forma sob a qual aparece aos nossos olhos. Trata-se de um objeto em transformação, enquanto não estiver concluído. Ao olharmos para o processo criativo de uma obra, estamos falando também de existência enquanto duração. Um fragmento de filme é o filme e não é o filme. Da mesma forma uma etapa segmentada de um processo é o processo, mas não é o processo como um todo. Precisa-se vivenciá-lo por inteiro para se concretizar a obra.

O processo de realização de um filme pode ser totalmente descontínuo, cada fragmento deste produto pode ser produzido em um tempo e lugar diferentes e no entanto estar presente na obra pronta de forma contígua. Já um filme como um produto é linear, é desfrutado como obra, ao longo de sua duração, naquele breve instante em que ele de fato se concretiza, enquanto é projetado, enquanto é visualizado.

A realização de um filme é vivenciada no tempo cronológico. Este, vai imprimindo suas marcas, conforme o processo de criação avança. O realizador, porém, convive com seu filme em um tempo que está fora do mundo, o tempo da obra, em sua forma latente. Ao se formular a idéia de um filme, ela talvez já se apresente imbuída deste tempo. Muitas vezes, ao se ler um roteiro, já consegue-se apreender qual será o

20 BERGSON, Henri. La pensée et le Mouvant, Paris, PUF, 1938 
tempo que será impresso no filme. Tarkovski em Esculpir o Tempo ${ }^{21}$ sugere que o tempo é a matéria da qual o cinema é feito. Ao longo do processo de realização, o diretor vai lidar com a questão de como imprimir este tempo no filme intuído por ele. $\mathrm{O}$ embate de um realizador está em materializar este tempo que ele sente a respeito de seu filme, ao longo de um processo que se desenrola em um tempo linear e que muitas vezes não segue um caminho linear para ser realizado. No momento em que um filme é visualizado em sua totalidade, estes dois tempos se encontram, o tempo da obra e seu tempo de duração. E neste tempo está implícito o tempo que levou para se concretizar como obra.

No cinema, conta-se anda com tempos de espera. Há filmes que levam muito tempo para que possam ser filmados. $\mathrm{O}$ filme ainda não existe enquanto obra, mas para seu diretor, aquela idéia vívida de ver algum dia seu filme, o alimenta. $\mathrm{O}$ faz seguir em seu processo. Alguns autores ressaltam a importância da passagem de tempo para o desenvolvimento de uma obra. Maurice Blanchot descreve em L'Espace Littéraire ${ }^{22}$ que a criação acontece ao longo do tempo e implica que obra e artista sofram transformações. No caso de A Via Láctea, Lina Chamie, em seu tempo de espera, resolveu mudar o titulo de seu filme, que se chamava inicialmente Onde Não Há Jardim optou também por modificar o roteiro para tentar manter um final feliz para seu filme, conforme veremos adiante. Porém, mesmo que nada de concreto aconteça, um filme é modificado em seu tempo de espera pois a duração do seu processo de realização é alterada. Esta obra e seu autor são outros, depois de o tempo transcorrido.

\footnotetext{
21 TARKOVSKI, Andrei. Esculpir o Tempo, São Paulo, Martins Fontes, 1998
}

22 BLANCHOT, Maurice. L'espace Littéraire, Paris, Éditions Gallimard, 1955 
Apesar de realização cinematográfica não seguir, necessariamente, um caminho linear, esta afirmação não contradiz o fato de o processo ser bastante planificado e convencionado em etapas. Um primeiro exemplo, como já foi dito, disso são as cenas, muito comumente gravadas fora da ordem que figurarão na obra pronta. Para que isto aconteça, durante a filmagem, atores são obrigados a desconstruir a narrativa da forma como ela aparece no roteiro e filmá-las seguindo a lógica do planos de filmagem, que, na maioria das vezes, ao serem estruturados, priorizam implicações de logística e otimização de recursos de produção empregados. O filme passa, neste momento, por uma das mortes que Bresson ${ }^{23}$ enumera, perde-se a estrutura colocada pelo roteiro em prol da linha de montagem que se estabelece ao longo de sua feitura. Tendo em vista esta primeira fragmentação, Suzana Amaral costuma trabalhar com seus atores vinculando cada cena do roteiro a uma intenção dramática que é sempre evocada por ela no momento da filmagem, para que o arco narrativo possa permanecer coerente para os atores. Veremos adiante na análise deste filme como a diretora procede e as implicações deste método.

Como foi visto até aqui, a feitura de um filme implica que o diretor esteja sempre projetando suas próximas etapas, mesmo enquanto realiza algo diante de seus olhos. As questões podem surgir imbricadas de maneira aleatória durante a feitura de um filme. As etapas na construção de um filme se seguem um a uma, mas da mesma maneira que as cenas não precisam ser gravadas em ordem, a escrita de um roteiro, ou mesmo a montagem em equipamentos mecânicos ou digitais, podem ser feitas de maneira aleatória. Ou seja, idas e vindas são perfeitamente cabíveis nestes processos de criação. Se por um lado, a realização de um filme pode seguir uma ordem própria, a

23 BRESSON, Robert. Notes sur le Cinématographe, Paris, Éditions Gallimard, 1988, 25 
obra só se concretiza, da maneira como foi projetada, no momento em que é visualizada.

\section{2 - Filmes e Cinemas}

Ismail Xavier em $O$ Discurso Cinematográfico ${ }^{24}$ separa os filmes entre os que buscam uma linguagem transparente e aqueles em que os realizadores optam pela opacidade. Bordwell em Sobre a História do Estilo Cinematográfico ${ }^{25}$ também salienta, ao longo da história, duas tendências distintas; uma de filmes que buscam reforçar o realismo como característica dominante no cinema. E outra das vanguardas, que manipulam a linguagem do cinema de forma plástica, tornando assim, mais evidente o aparato cinematográfico.

Podemos entender, grosso modo, pela opacidade, colocada por Xavier, filmes que tornam aparentes a própria linguagem cinematográfica, ou explicitam a maneira como é feita a obra e pela transparência o desaparecimento do aparato cinematográfico por traz de uma narrativa, desenvolvida a partir de personagens. Nestes filmes, desejase que o processo de realização não possa ser identificável em seu produto final, pois em nenhum momento o espectador deve ter consciência de que está vendo um filme. Já nos filmes que trabalham a opacidade, torna-se evidente para o espectador a mão do diretor, ou como e por que algumas escolhas foram feitas, em relação ao modo de filmar, à montagem, à justaposição de sons e imagens, entre outros recursos.

Quando comparamos A Via Láctea e Hotel Atlântico, levando em conta este aspecto podemos encontrar em um e outro filme momentos de maior ou menor

\footnotetext{
24 XAVIER, Ismail. O Discurso Cinematográfico: Opacidade e transparência, São Paulo, Paz e Terra, 2005 - $3^{\mathrm{a}}$ edição 25 BORDWELL, David. Sobre a História do Estilo Cinematográfico, Campinas, Papirus, 2013
} 
opacidade. Mas, de modo geral, em Hotel Atlântico, Suzana Amaral trabalha de forma predominante a chave da transparência. Ou seja, os recursos agenciados e a maneira como são utilizados na construção de seu filme, contribuem para o protagonismo da representação da realidade. Para Suzana, os atores e a narrativa contada por eles são os elementos mais importantes de seu filme, a maneira como usa som e imagens, ou como articula os planos na montagem são recursos para dar suporte a esta narrativa. Em alguns momentos esta construção é mais aparente, em outros menos, como veremos.

Lina Chamie não fabrica exatamente um filme metalinguiístico, mas usa-se de recursos como a construção ou desconstrução do espaço e a manipulação da linguagem como partes integrantes da narrativa.

O espectador é, muitas vezes, surpreendido por alterações que interferem em sua percepção do filme; a mudança no suporte de captação entre mini dv e $35 \mathrm{~mm}$ em uma única cena, a alteração da velocidade da câmera, sons deslocados em relação às suas imagens são recursos que a diretora emprega e que integram a maneira como esta narrativa nos é apresentada. Os recursos que o cinema disponibiliza como parte de seu meio são explicitados em A Via Láctea, não para desconstruir seu aparato, mas como maneira de expressão desta diretora. Ao abrir seu filme com uma seqüência em que vemos o protagonista atravessar a rua inúmeras vezes e depois repetí-la sob o ponto de vista de um motorista, dentro de um carro que se aproxima do personagem principal, percebe-se que este filme não pretende seguir uma estrutura clássica de narrativa. É uma questão formal; Chamie trabalha com as possibilidades que o cinema apresenta para encontrar uma maneira singular de narrar a história em questão.

Alguns traços não se apagam da obra, as escolhas do realizador resultam no filme como um todo e estão implícitas, quando não explícitas, em seu produto final. 
Por exemplo a escolha em se filmar em $35 \mathrm{~mm}$, super $16 \mathrm{~mm}$, ou mini dv é uma escolha que permanece aparente ao espectador. Mas, tanto em filmes cuja linguagem é pautada pela transparência, como em filmes que possuem uma opacidade maior ou imbricada em sua narrativa, podemos falar da experiência estética que estas obras nos proporcionam, porém, não podemos, unicamente a partir de um filme pronto, ter acesso ao processo de realização deste como um todo.

\section{3 - Poética}

Se compararmos um filme a outras obras, uma pintura ou escultura, que equivalências poderíamos encontrar que denotassem uma marca do artista? O que seria equivalente a uma pincelada ou a entalhes em um determinado material no corpo de um filme, que permitissem identificar caminhos percorridos por seus criadores? A decupagem? A direção de atores? A montagem? O maior enfoque dado a cada uma destas áreas, em detrimento de outras em um filme é o que definiria o estilo de cada diretor ao se fazer um filme, segundo Bordwell ${ }^{26}$. Neste sentido, sua definição de estilo se aproxima da definição de poética que trabalharemos nesta pesquisa. O autor ressalta ainda em seu livro ${ }^{27}$ que em cada momento da história do cinema, cineastas, historiadores e críticos tentaram estipular o que seria a essência do cinema e com isso definir quais aspectos deveriam ser relevantes em uma obra: a montagem ou a quase ausência desta, o roteiro ou narrativa, a composição, a profundidade de campo, a miseen-scène. Da mesma forma que a poética, o estilo estaria circunscrito a uma determinada época.

26 BORDWELL, David. Sobre a História do Estilo Cinematográfico, Campinas, Papirus, 2013, pg. 17

27 Ibid. 
Aumont salienta em A Teoria dos Cineastas: "O cineasta é um criador de um tipo particular: "sem mãos", sem relação imediata com qualquer material ou ferramenta." ${ }^{28}$ Consideramos a afirmação de Aumont no se refere ao trabalho principal do diretor, que é pensar o filme como um todo, concretizar, escolha após escolha, sua obra.

Durante a produção de um único filme, um cenário pode ter sido concebido com diferentes cores até que se chegasse ao resultado final na cópia. Um personagem pode ter sido sonhado por um diretor com certas características que correspondiam a um determinado ator. Mas no final este mesmo diretor se viu obrigado a aceitar que fosse interpretado por outra pessoa, por contingências da realidade.

Em um único filme, quantas possibilidades de outros filmes não foram deixadas para trás? E quanto do que se vê no resultado final não constitui apenas uma porção ínfima do que foi em sua preparação, como a ponta de um iceberg que esconde todo o processo latente embaixo d’água? "A obra está sempre em estado de provável mutação, assim como há possíveis obras nas metamorfoses que os documentos preservam" ${ }^{\text {29 }}$ Marcel Duchamp traduz como a "diferença entre o que se quis realizar e o que na verdade se realizou". ${ }^{30}$ Bresson ${ }^{31}$ evoca as mortes ou metamorfoses de uma etapa em outra. Poderíamos também considerar as mortes como sendo a de todos estes outros filmes presentes de forma virtual no início da criação, e que vão sendo deixados para trás, após cada decisão tomada, ao longo do processo?

\footnotetext{
28 AUMOnT, Jacques. A Teoria dos Cineastas, Papirus, Campinas, 2004, pg. 13

29 SALLES, Cecília A. Gesto inacabado. Processo de criação artística, São Paulo, Fapesp/Anabluni, 2004, $3^{\text {a }}$ edição, pg. 26

$3^{0}$ DUCHAMP, Marcel. O Ato Criador, in A Nova Arte - Organização Gregory Battock - São Paulo, Editora

Perspectiva, 1975, pg. 73

${ }^{31}$ BRESSON, Robert. Notes sur le Cinématographe, Paris, Éditions Gallimard, 1988, pg. 25
} 
Como, no entanto, poderíamos proceder para apreender este processo e transformá-los em um conhecimento acerca da criação artística em determinado campo, e que pode ser transmitido? Cada obra possui um percurso único de realização e existem tantos processos criativos quanto existem filmes. O processo de criação é cumulativo, mas nunca passível de ser reproduzido. Mas, a cada obra, o artista acumula um saber que pode ser transmitido a outros artistas, que poderão utilizá-lo como referências para outras criações.

Muitos diretores falam de seus filmes, com seus pontos de vistas únicos de quem engendrou a criação de determinada obra. Mas, referente à realização de filmes, existe uma bibliografia escassa no que diz respeito ao processo formativo das obras. E com exceção de alguns filmes, que tratam do seu próprio processo de constituição, a tendência é que o modo como se operou e o método utilizado para se construir a obra se apaguem de seu produto final.

René Passeron coloca em seu livro Pour une Philosophie de la Création ${ }^{32}$ que os estudos da poética se voltem para o desenvolvimento da "Arte que se faz",33. Escolhemos desenvolver uma discussão acerca da criação a partir da observação de processos que levaram à criação de determinadas obras cinematográficas. Interessa-nos observar como certos autores, articulam-se em uma rede de criação para levar adiante um projeto; como fatores externos influenciaram nas tomadas de decisão; como o filme abandona suas diversas formas para se metamorfosear sempre em uma nova, até chegar ao formato que será apresentado ao público. Busca-se discutir com este enfoque, como podemos nos aproximar das práticas instauradoras na criação cinematográfica.

\footnotetext{
32 PASSERON, René. Pour une philosophie de la Création, Editions Klincksieck, 1985

33 Ibid., pg. 16
} 
Jacques Aumont, na tentativa de confrontar as diversas formulações teóricas acerca do cinema, deixadas por realizadores, desenvolveu, em A Teoria dos Cineastas $^{34}$, uma compilação na qual analisa e comenta os textos de alguns cineastas, relacionandoos às suas obras. Aumont chama a atenção para o fato que tratam-se de teorias, muitas vezes, que nem mesmo os próprios diretores as seguem. Aumont classifica-as mais como reflexões acerca do cinema, que podemos, de um certo modo, assimilar como parte do conjunto da obra dos diretores que as deixaram “(...) O cineasta é um homem que não pode evitar a consciência de sua arte, a reflexão sobre seu ofício e suas finalidades, e em suma o pensamento." ${ }^{35}$ Como vimos anteriormente, a fragmentação em diferentes momentos da criação leva o cineasta a tomar decisões em sua obra que terão consequiências disseminadas ao longo de todo o processo. A ação do cineasta não se encerra no presente, ela percorre o processo em toda sua duração.

A formulação teórica de alguns cineastas nos serve para elucidar questões relativas à poética empregada na realização dos filmes, pois, como ressalta Aumont, “as teorias elaboradas por alguns se refletem na prática de todos os outros, pelo menos no ponto em que as práticas são comparáveis." ${ }^{36}$ Esta observação de Aumont parece-nos interessante pois não refuta o fato de que cada criação é singular, mas abre-se, a partir dela, a busca por similaridades e analogias nos movimentos criativos. Com isso, podemos pensar a criação como algo que não se encerra em uma única obra, mas como um processo que continua através de influências de uma obra em outra, e, finalmente como um conhecimento que pode ser transmitido.

\footnotetext{
34 AUMONT, Jacques. A Teoria dos Cineastas, Papirus, Campinas, 2004

35 Ibid. pg.7

36 Ibid., pg.12
} 
Nossos estudos sobre o processo de criação cinematográfica, serão, desta forma, pautados pelas discussões e conceituações acerca da poética como uma filosofia da criação, a partir do que propõem René Passeron, mas também Paul Valéry, entre outros teóricos que se dedicam ao estudo da criação, conforme desenvolveremos adiante. Levaremos em consideração também para este estudo A Teoria dos Cineastas $^{37}$ de Jacques Aumont e Sobre a História do Estilo Cinematográfico ${ }^{38}$, de David Bordwell.

Evocaremos a conceituação de poética para analisar uma obra em seu processo formativo. "Discutir arte sob o ponto de vista de seu movimento criador é acreditar que a obra consiste em uma cadeia infinita de agregação de idéias"39 Passeron em Pour une Philosophie de la Création ${ }^{40}$ entende por poética o conjunto de estudos dedicado à instauração de uma obra, sobretudo no que diz respeito à criação artística; seu objeto de estudo é a própria criação. Passeron propõem estudar as variantes que interferem em um processo criativo, tendo em vista compreender a obra enquanto esta se instaura: “(...) a poética, embasada sobre fatos precisos, parece-nos poder ser uma reflexão normativa sobre a atividade instauradora no domínio da arte." ${ }^{\text {41 }}$ Como outros autores que veremos adiante, a conceituação de poética proposta por Passeron, contextualiza a obra em seu tempo histórico e seu criador, como sendo um reflexo deste tempo ao qual está preso. O autor de uma obra interessa a Passeron enquanto está ligado à sua obra, enquanto se ocupa do ofício da criação. Pois a obra é fruto de suas decisões, síntese de

\footnotetext{
37 AUMONT, Jacques. A Teoria dos Cineastas, Papirus, Campinas, 2004

38 BORDWELL, David. Sobre a História do Estilo Cinematográfico, Campinas, Papirus, 2013

39 CALVINO , 1990 in SALLES, Cecília A. Gesto inacabado. Processo de criação artística, São Paulo, Fapesp/Anabluni, 2004, $3^{\text {a }}$ edição, pg. 25

40 PASSERON, René. Pour une philosophie de la Création, Editions Klincksieck, 1985

41 "(...)la poïetique, appuyée sur de faits précis, nous semble pouvoir être une réflexion normative sur l'activité instauratrice dans le domaine de l'art." PASSERON, René. Pour une philosophie de la Création, Editions Klincksieck, 1985, pg. 21, t.n.
} 
todas as influências, vivências, embates e descobertas que este autor possa ter sofrido ao longo de sua vida.

Contemporâneo aos estudos de Passeron, Luigi Pareyson, em Os Problemas da Estética, também ressalta a importância de vislumbrarmos a criação dentro de um contexto temporal e histórico: "A poética é um programa de arte declarado num manifesto, numa retórica ou mesmo implícito no próprio exercício da atividade artística; ela traduz em termos normativos e operacionais um determinado gosto, que por sua vez, é toda a espiritualidade de uma pessoa ou de uma época projetada no campo da arte." ${ }^{42}$

Umberto Eco em A Obra Aberta $^{43}$ define a poética como um programa operacional que o artista estipula para si mesmo ao realizar uma obra. É um conjunto de regras ou preceitos que o artista elencou para si e que será seguido como leis que devem reger o universo artístico sobre o qual ele está trabalhando. Veremos adiante, junto a outros autores, que muitas vezes o artista parte de ações conscientes para estipular os parâmetros de sua criação, mas muitas vezes estes aparecem de forma inconsciente ou até como obras do acaso. Bresson ao pensar na teoria do Cinematógrafo trata do acaso como um fator importante ao se fazer um filme. Com todos elementos agenciados, o artista deve estar atento para o que se manifesta como obra do acaso, dentro daquilo que ele recortou como seu campo de ação.

Paul Valéry descreve, como ao longo da história, certas correntes artísticas "admitiam ser submetidas, de acordo com a natureza de cada uma, a certas formas ou modos obrigatórios que se impunham a todas as obras do mesmo gênero"44 e que estiveram associadas à noção de poética durante muito tempo. Valéry defende, no

\footnotetext{
42 PAREYSON, Luigi. Os Problemas da Estetica, São Paulo, Martins Fontes, 1989 - $2^{\mathrm{a}}$ edição, pg. 21

43 ECO, Umberto. A obra aberta. São Paulo, Perspectiva, 2001

44 VALÉRY, Paul. Variedades, Iluminuras, São Paulo, 2007,pg. 180
} 
entanto, que para se compreender o que vem a ser a poética, devemos buscar em sua raiz etimológica e que sua definição está ligada ao fazer que resulta em alguma obra: "Pode acontecer que se adquira por essa curiosidade um interesse tão vivo, que se atribua importância tão grande em segui-la, que sejamos levados a considerar com mais complacência, e até com maior paixão , a ação que faz do que a coisa feita." ${ }^{45}$ Mesmo se as reflexões relacionadas à Poética, desenvolvidas por Valéry estão mais vinculadas à criação da poesia, podemos entender suas proposições dentro de um contexto maior, que abriga a criação de modo geral, sobretudo a artística.

Ainda, para Paul Valéry, a criação artística é resultado de dois modos de operação, o intuitivo e o racional: "Em suma, numa obra de arte, dois elementos constituintes estão sempre presentes: primeiro aqueles dos quais não concebemos a origem (a geração), que não podem ser expressos em atos, embora possam depois ser modificados por atos; segundo, os que são articulados, podendo ser pensados." ${ }^{46}$

Vimos anteriormente, como a divisão em etapas no processo de criação cinematográfica pode auxiliar em sua organização. Da mesma maneira, na tentativa de explicar o fenômeno que é a criação, tende-se a dividi-lo em etapas para melhor apreendê-lo. A observação dos processos criativos, no entanto, nos apontam para caminhos em que as causas, ou etapas, quaisquer que sejam, embora possam ser identificadas, não se apresentam de forma linear no âmago da criação. Vemos com frequiência os movimentos de idas, vindas e reviravoltas que constituem a criação artística. "Nesta perspectiva, pode-se entender o ato de criar como uma construção em

\footnotetext{
45 VALÉRY, Paul. Variedades, Iluminuras, São Paulo, 2007, 181

46 "En somme, dans l'œuvre d'art, deux constituants sont toujours présents : $I^{\circ}$ ceux dont nous ne concevons pas la génération, qui ne peuvent s'exprimer en actes, quoiqu'ils puissent ensuite être modifiés par actes ; $2^{\circ}$ ceux qui sont articulés, ont pu être pensés." VALÉRY, Paul. L'Invention Esthétique, In Oeuvres I, Paris, Gallimard, 1957, t.n., pg. 141,
} 
movimento, um processo dinâmico, na condição de sempre poder vir a ser." ${ }^{, 47}$ Dentre a maioria dos autores, a criação sempre aparece ligada à invenção, ou à realização de algo ou alguma informação que antes não existia. "A desordem é essencial à criação, enquanto esta se define por uma certa "ordem"."48 Desta forma Valéry evoca este processo da passagem de uma desordem à ordem como um rearranjo de elementos que já estavam lá, sob uma forma nunca antes concebida. O que nos leva a pensar na “cadeia infinita de agregação de idéias" ${ }^{49}$ de Calvino.

A poética opera no sentido de construir o objeto de arte e tem como objetivo a operatividade, como o fazer que se faz à medida que se inventa. $\mathrm{O}$ artista opera entre o método que estabelece para si e o modo como coloca este método em prática.

"Não há portanto uma teoria fechada anterior ao fazer. A ação da mão do artista vai revelando esse projeto em construção. As tendências poéticas vão se definindo ao longo do percurso: São leis em estado de construção e transformação." 50

Desta forma, iremos considerar para este projeto de pesquisa, a poética como o modo e o método pelo qual cada obra, particularmente, se realiza, ligados ao contexto em que se deu esta produção e considerando os movimentos que fizeram parte deste movimento criado. Interessa-nos, portanto, observar um filme, não do ponto de vista de seu produto finalizado, mas no momento de sua elaboração. Iremos tratar do processo de criação, partindo do ponto de vista que cada processo que envolve a elaboração de uma obra é único. Embora possa apresentar similaridades ou procedimentos em comum com a realização de outras obras do mesmo gênero.

\footnotetext{
47 TAVARES, Mónica. Processos de Criação na Arte In: Processos de Criação na Educação e nas Artes, Organização Alberto Roiphe e Sumaya Mattar, São Paulo, Escola de Comunicações e Artes, 2012, pg. 37

48 "Le désordre est essentiel à la « création », en tant que celle-ci se définit par un certain « ordre »" VALÉRY, Paul. L'Invention Esthétique, In Oeuvres I, Paris, Gallimard, 1957, t.n., pg.142

49 CALVINO, 1990 in SALLES, Cecília A. Gesto inacabado. Processo de criação artística, São Paulo,

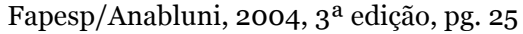

50 SALLES, Cecília A. Gesto inacabado. Processo de criação artística, São Paulo, Fapesp/Anabluni, 2004, $3^{\text {a }}$ edição, pg. 40
} 


\section{4 - A Criação em rede}

Tendo em vista observar o percurso formativo de uma obra cinematográfica, uma das questões que se coloca acerca do processo criativo no cinema é o fato de este ser uma criação coletiva. A realização, no cinema, não está concentrada apenas nas mãos do diretor, mas se divide entre os diversos membros da equipe e as influências entre os criadores envolvidos são mutuas.

Além da figura do diretor, outros membros da equipe e elenco deverão colaborar e trabalhar em seus departamentos para que o filme se realize. E mais, o trabalho de um membro da equipe ou elenco não é independente do de outro. Para um resultado coerente, todos devem caminhar em uma mesma direção, mesmo que inicialmente tenham concepções distintas de como seria este filme. Realizar um filme implica numa cadeia de decisões em série. As decisões tomadas permeiam sempre mais de um departamento e afetam o resultado do filme como um todo.

Apesar da tendência em se dividir a criação cinematográfica em etapas que compreendem seus principais movimentos, não devemos entender que este processo criativo se desenvolva em uma única direção. Podemos considerar, de modo geral, que a criação no cinema acontece como uma criação em rede e se estende em diversas direções, realizada por seus diversos criadores envolvidos. As decisões tomadas por cada membro da equipe se vêem ligadas às dos demais e afetam os diversos departamentos. À medida que os criadores avançam em suas escolhas uma trama de ações vai se formando e formando o filme.

Mas no que exatamente consiste a criação em rede? Cecília Salles em Redes da Criação $^{51}$ atenta para o fato de que nenhum artista cria sozinho, pelo simples fato de

51 SALLES, Cecília A. Redes de Criação, São Paulo, Horizonte, 2006 
este pertencer a uma determinada época e sofrer influências de seu tempo, de outros artistas e do meio em que vive. Da mesma forma, os autores que utilizamos para a conceituação do que vem a ser a Poética também ressaltam a criação como algo localizado no tempo e no espaço. No entanto, no cinema temos a especificidade de se tratar de uma arte que, majoritariamente, depende da criação coletiva, mesmo que muitas vezes o trabalho seja exclusivamente creditado a um diretor.

“Algumas artes são elas mesmas, por definição como sínteses de práticas e mesmo síntese de artes." ${ }^{, 2}$ Podemos dizer que segundo Passeron, poderíamos pensar o cinema como a síntese de várias artes, envolvendo a criação de artistas de universos distintos, inclusive. Como relembra Passeron: “(...) existem nuances decisivas na definição da noção em si, da criação coletiva.. ${ }^{53}$ E podemos afirmar, em relação ao cinema, que o grau de colaboração varia de obra para obra.

Nos filmes enfocados nesta pesquisa, veremos, na procedência das análises de $A$ Via Láctea ${ }^{54}$ e Hotel Atlântico ${ }^{55}$, como os diversos colaboradores se vêem envolvidos e são necessários para a realização destas obras. A título de exemplo, lembramos que em 2000, quando ministrava aula de direção cinematográfica, no curso de Cinema e Vídeo, na ECA Suzana Amaral relatou a seus alunos um exemplo de como procedeu em seu primeiro filme, A Hora da Estrela (1985), para ajudar a atriz Marselha Cartaxo na composição de sua personagem Macabéia, utilizando-se, pra isso, de uma peça do figurino. Ela descreve que deu à atriz, dois meses antes do início das filmagens, uma camisola com a qual ela deveria dormir, sem lavar, todos os dias e que seria usada

\footnotetext{
52 "Certains Arts, sont eux-mêmes, par definition, des syntheses de pratiques et meme des syntheses d'art" PASSERON, René. Pour une philosophie de la Création, Editions Klincksieck, 1985, t.n. pg.58

53 "il y va de nuances décisives dans la mise au point de la notion meme de creation collective." Ibid, t.n., pg.59

54 CHAMIE, Lina. A Via Láctea, São Paulo, Girafa Filmes, 2007

55 AMARAL, Suzana. Hotel Atlântico, São Paulo, Planifilmes, 2009
} 
depois em cena. Seu objetivo abrangia questões ligadas obviamente à direção de atores, mas também ao figurino e à direção de arte. Com isso ela pretendia que a atriz sentisse a miséria que assolava a personagem, que não podia nem mesmo contar com uma muda de roupa para dormir. Além disso, ela esperava dar à camisola um aspecto de realmente usada, desgastada. Em relação às marcas de desgaste do tempo, no figurino, existem outras técnicas e recursos disponíveis aos figurinistas, que não foram colocadas em prática. Era importante, para Suzana Amaral, que, de alguma forma esta imposição de dormir todos os dias com a mesma camisola afetasse a própria atriz em seu trabalho de criação da personagem e que ela reconhecesse cada marca do tempo, deixada nesta peça do figurino. As emoções e sentimentos que deveriam aflorar em cena, já estavam sendo preparados algum tempo antes do momento crucial da filmagem.

Este exemplo de Suzana Amaral descrito acima nos interessa, sobretudo, quando atentamos a este aspecto da criação em rede que envolve a feitura de um filme. Talvez num primeiro momento, o filme surja como uma possibilidade de algo a ser feito apenas para uma pessoa; o diretor, ou um roteirista, mas logo outros colaboradores serão chamados para colocar a engrenagem em funcionamento. Um produtor será chamado para levantar custos e recursos para se realizar o projeto, talvez um roteirista, dependendo da maneira como o roteiro for desenvolvido.

Já na pré-produção a obra em questão pode chegar a contar com dezenas de colaboradores. Alguns com funções mais criativas e deliberativas, outros com a incumbência de executar os projetos concebidos pelos chefes de equipe. No entanto, para que a obra avance rumo a sua concretização, é importante que todos caminhem juntos. Isto quer dizer que muitas vezes o trabalho de um membro da equipe depende que determinada decisão seja tomada por outro, para poder avançar em suas escolhas. 
Um diretor de arte, muitas vezes é obrigado a esperar a definição por uma locação para que possa continuar a conceber seu cenário. Idem um figurinista, que deve esperar que o ator seja definido para poder de fato deliberar sobre o figurino.

Exemplos positivos também podem surgir e o trabalho de um membro da equipe se complementar pelo fato de outras pessoas estarem pensando em outros aspectos desta criação. Por exemplo, um ator pode se beneficiar imensamente da prova e escolha de figurinos para compor seu personagem. A própria concepção da imagem é algo que se dá através do processo colaborativo entre diretor, diretor de fotografia e diretor de arte, sendo que as nuances e o peso da colaboração de cada um destes, varia de filme para filme, conforme sugere Passeron acerca da criação coletiva.

Ainda em Notas Sobre o Cinematógrafo ${ }^{56}$, Bresson fala sobre o processo de filmagens: "Filmar é como ir a um encontro. Nada do inesperado que não seja esperado secretamente por você mesmo." ${ }^{57}$ Em uma criação coletiva ou em rede, mesmo que haja uma pessoa centralizando as tomadas de decisão, como o caso do diretor, abre-se mão do controle absoluto. As inter-relações no momento em que a criação de fato acontece, preponderam sobre o fato de que existe um projeto anterior. $\mathrm{O}$ mesmo poderia se dizer de uma orquestra, por exemplo. Aumont, analisa esta mesma passagem, citada acima, de Bresson:

"É o cosmos que de fato se manifesta neste encontro - isto é, o mundo, mas organizado pelo homem (cosmos designa o contrario do Caos); ao contrario de todas as leituras idealistas ou transcendentalistas desse tema, que imaginavam que um "mundo" falaria por si só (isto é, finalmente, por meio do qual Deus falaria), o encontro só acontece no cinematógrafo porque este é um trabalho, uma escrita." ${ }^{, 58}$

56 BRESSON, Robert. Notes sur le Cinématographe, Paris, Éditions Gallimard, 1988

57 “Tourner c'est aller à une rencontre. Rien dans l'inattendu qui ne soit attendu secrètement par toi." BRESSON, Robert. Notes sur le Cinématographe, Paris, Éditions Gallimard, 1988, t.n. pg. 104

58 AUMONT, Jacques. A Teoria dos Cineastas, Papirus, Campinas, 2004, pg.18 
Esta reorganização necessária para que haja o encontro, engloba elenco e equipe. Valéry e outros autores entendem este rearranjo da ordem de elementos que já estavam presentes no mundo em uma nova estrutura como o cerne da criação.

Gaston Bachelard, em La Poétique de L'espace ${ }^{59}$, fala sobre o processo de criação contínua ao se referir ao leitor como um co-criador daquilo que está lendo. Ele utiliza-se da fenomenologia para explicar o fato de a linguagem poética evocar, ou melhor provocar sensações no leitor, por esta não utilizar os códigos convencionais da linguagem. Ele descreve este fenômeno como a reverberação de experiências pessoais no centro da sensibilidade do leitor, no momento em que este entra em contato com o texto.

"Como este evento singular e efêmero que é o aparecimento de uma imagem poética singular, pode reagir - sem nenhuma preparação - sobre outras almas, em outros corações, e isto, apesar de todas as barreiras do senso comum, dos pensamentos prudentes, contentes de suas imobilidades?

(...) A fenomenologia, quer dizer a consciência do ponto de partida da imagem em uma consciência individual pode nos ajudar a restituir a subjetividade das imagens e a medir a amplitude, a força e o sentido da trans-subjetividade desta imagem." ${ }^{60}$

O princípio de uma criação em rede, como a do cinema, em que a criação se dá em momentos diferentes e em várias direções, pode ser comparado ao processo fenomenológico que descreve Bachelard. Os diversos co-autores colocam suas sensibilidades a serviço desta obra e tentam traduzir em seus trabalhos em imagens mentais fomentadas partir da leitura de um texto, no caso, o roteiro.

\footnotetext{
59 BACHELARD, Gaston. La Poétique de L'espace, Presse Universitaire de France, Paris, 1957

60 “Comment aussi cet événement singulier et éphémère qu'est l'apparition d'une image poétique singulière, peut'il réagir - sans aucune préparation - sur d'autres âmes, dans d'autres coeurs, et cela, malgré tous les barrages du sens commun, tout les toutes les sages pensées, heureuses de leur immobilité?" "La phenomenologie - c'est-à-dire, la considération du départ de l'image dans une conscience individuelle - peut nous aider à restituer la subjectivité des images et à mesurer l'ampleur, la force, Le sens de la transubijectivité de l'image." BACHELARD, Gaston. La Poétique de L'espace, Presse Universitaire de France, Paris, 1957, t.n. $\operatorname{pg} .3$
} 
"A imagem poética não esta submetida a uma pulsão. Ela não é o eco de um passado. É antes de tudo, o contrário: pelo clarão de uma imagem, o passado distante ressoa de ecos e vemos assim, a que profundeza estes ecos vão repercutir e se extinguir. Em sua novidade, em sua atividade, a imagem poética tem um estado próprio, um dinamismo próprio." 61

É como se a criação artística devesse percorrer um caminho entre os diversos membros de uma equipe de trabalho, para que esta criação seja compartilhada, pois apesar da segmentação de tarefas envolvida em se fazer um filme, existem todas as subjetividades colocadas a serviço desta criação. Bachelard afirma que a imagem oferecida pela leitura de um poema se torna verdadeiramente pessoal, pela ressonância que cria em nós. Podemos considerar que não apenas a leitura de um texto poético, mas o contato com qualquer obra de arte poderia despertar estes mesmo ecos da criação:

"Nós a recebemos, mas ela nasce em nós à impressão de que poderíamos tê-la criado, que nós deveríamos tê-la criado. Ela se torna um novo ser de nossa linguagem, ela nos exprime ao provocar em nós, o que ela exprime (...)"62

A diretora de fotografia Andréa Scansani, em discussão com um grupo de pesquisa acerca da poética, afirma sobre o seu trabalho:

"Ao ler um roteiro eu vou buscar entender o que a cena quer dizer e vou tentar traduzir com o meu trabalho na fotografia do filme a sensação que esta cena deve passar ao espectador, sem recorrer ao uso de palavras. A cena pode conter os diálogos, que o diretor ou o roteirista vão trabalhar, mas o meu papel dentro da equipe é dizer isto de uma outra forma." ${ }^{\prime 3}$

Esta outra forma a que ela se refere é apenas sensível, como a própria diretora de fotografia coloca, não faz utilização de uma linguagem verbal para descrever sensações,

61 “ L'image poétique n'est pas soumise à une poussée. Elle n'est pas l'écho d'un passé. C'est plutôt l'inverse: par l'éclat d'une image, le passé lointain résonne d'échos et l'on ne voit guère à quelle profondeur ces échos vont se répercuter et s'eteindre. Dans sa nouveauté, dans son activité, l'image poétique a un être propre, un dynamisme propre.” Ibid., t.n., pg. 1

62 “Nous l'avons reçue, mais nous naissons à l'impression que nous aurions pu la créer, que nous aurions dû la créer. Elle devient un être nouveau de notre langage, elle nous exprime en faisant ce qu'elle exprime (...) BACHELARD, Gaston. La Poétique de L'espace, Presse Universitaire de France, Paris, 1957, t.n. pg.7

63 SCANSANI, Andréa, Depoimento em 28/04/2014 
que no entanto estão contidas em um roteiro ou em um projeto com o qual teve contato. Seu papel como membro criador de uma equipe só pode ser acionado a partir do momento em que disponibiliza sua sensibilidade em um primeiro momento e, posteriormente, que traduza o fenômeno que se produziu em seu espírito como um elemento concreto do filme, no caso a fotografia.

A criação em rede se estende ao longo de todo o processo de realização de uma obra cinematográfica, sendo que os colaboradores variam ao longo do processo. Também varia a quantidade de pessoas envolvidas em cada uma das etapas. Poucos são os que acompanham o processo do início ao fim; em geral o diretor e muitas vezes o produtor ou produtor executivo, sendo que destes o diretor é aquele que possui função mais criativa.

\section{5 - O Papel do Diretor}

Nestas inter relações formadas pela rede de criação, ou pela criação coletiva, iremos nos deter, como já foi dito, na figura do diretor, a quem, na maioria das vezes, compete tomar as derradeiras decisões. Jacques Aumont em A Teoria dos Cineastas $^{64}$ alega, para defender sua escolha em delimitar seu campo de estudo às teorias propostas pelos diretores, que a História do Cinema foi feita majoritariamente por diretores. Ou, em todo caso, estes se valeram do crédito de suas obras. Certamente, uma outra abordagem, mais ampla, seria possível, levando-se em conta as contribuições teóricas trazidas por diretores de fotografia, roteiristas e montadores, mas também teóricos e críticos.

64 AUMONT, Jacques. A Teoria dos Cineastas, Papirus, Campinas, 2004 
Nesta pesquisa, as contribuições do restante da equipe serão analisadas e consideradas do ponto de vista colaborativo. Principalmente pois, como afirmamos acima, a criação coletiva no cinema se dá simultaneamente, diversos fatores devem caminhar em paralelo para que uma única tomada seja rodada.

Marcelo Müller em sua dissertação Estratégias da Direção: Processo de realização em Longas Metragens Contemporâneos Brasileiros "65 traz a dificuldade em se encontrar na bibliografia de autores brasileiros, uma definição sobre o que vem a ser o trabalho do diretor. A única definição que este encontra, de que o

"Diretor Cinematográfico: cria a obra cinematográfica, supervisionando e dirigindo sua execução, utilizando recursos humanos, técnicos e artísticos; dirige artisticamente e tecnicamente a equipe e elenco; analisa e interpreta o roteiro do filme, adequando-o à realização cinematográfica sob o ponto de vista técnico e artístico; escolhe locações, cenários, figurinos, cenografias e equipamentos; dirige ou supervisiona montagem, dublagem, confecção da trilha musical Sonora, e todo o processamento do filme até a cópia final; acompanha a confecção do trailer, do avanttrailer." $" 66$

Esta definição provém do SINDICINE, a qual Müller considera bastante centralizadora, mas alega que esta mesma definição "nos faz entender que o diretor é aquele que concentra a criação da obra e está presente durante todo o processo, do início até a distribuição da obra" ${ }^{, 67}$ Cecília Salles ${ }^{68}$ recupera a afirmação de Kurosawa e nos fornece uma chave para entendermos o papel criativo do diretor como o interlocutor que concentra as tomadas de decisão, mas também como aquele que faz a ponte entre os diversos setores ou departamentos que um filme tem.

\footnotetext{
65 MÜLLER, Marcelo. Rodrigo Mingoti, FRANCO, Marília da Silva Estratégias da direção processos de realização em longas metragens brasileiros contemporâneo, Tese de Mestrado - Universidade De São Paulo, Escola de Comunicações e Artes, 2010 66 http://www.sindicine.com.br/site/profissionais.asp\# acesso em 20 de julho de 2010) in MÜLLER, Marcelo. Rodrigo Mingoti, FRANCO, Marília da Silva Estratégias da direção processos de realização em longas metragens brasileiros contemporâneo, Tese de Mestrado - Universidade De São Paulo, Escola de Comunicações e Artes, 2010, pg.21

67 Ibid. pg. 21

68 SALLES, Cecília A. Gesto inacabado. Processo de criação artística, São Paulo, Fapesp/Anabluni, 2004, $3^{\text {a }}$ edição
} 
"O trabalho de um diretor envolve o treino dos atores, a técnica cinematográfica, a gravação sonora, a direção de arte, a música, a edição, a dublagem e a mixagem do som. Embora estas possam ser pensadas como ocupações separadas, eu não vejo como independentes entre si. Eu as vejo juntas, mesclando-se sob o comando de uma direção."

Para cada diretor, o processo é muito particular. Um diretor pode, ao longo de seu percurso, na passagem de um filme a outro, ir decantando um método, acumulando uma experiência da qual busca se utilizar em seu próximo exercício de realização. E no entanto, a cada projeto deve começá-lo como se não soubesse nada, pois de fato não sabe. É preciso que

"o saber seja acompanhado de um igual esquecimento do saber. O não saber não é uma ignorância, mas um ato difícil de desapego da consciência. É a este preço, que uma obra é a cada instante esta forma de começo puro, que faz de sua criação um exercício de liberdade." ${ }^{70}$

Estas duas, tendências coexistem no exercício cinematográfico; o planejamento e a busca pela renovação de um processo. Este conflito se resolve, para cada diretor, de uma maneira diferente.

Em geral, os cineastas ao elaborarem suas teorias, tiveram a chance de observar, ao longo de seus trabalhos, como este processo, que é particular se dá. Bresson ao criar seus conceitos em Notas Sobre o Cinematógrafo ${ }^{71}$, apóia-se em sua experiência pessoal, da qual decantou seu método de trabalho, para atingir um resultado bastante particular. E sobre o qual seus escritos falam. É toda sua forma de criar que está expressa nestes seus aforismos, por isso a coerência tão profunda entre o que se lê e o que se apreende de seus filmes.

\footnotetext{
69 KUROSAWA, Akira in SALLES, Cecília A. Gesto inacabado. Processo de criação artística, São Paulo, Fapesp/Anabluni, 2004, $3^{\mathrm{a}}$ edição, pg. 50

70 "Il faut docn que le savoir s'accompagne d'un égal oubli de le savoir. Le non-savoir n'est pas une ignorance mais un acte difficile de dépassement de la connaissaince. C'est à ce prix qu'une oeuvre est à chaque instant cette sorte de commencement pur qui fait de sa creation un exercise de liberté." BACHELARD, Gaston. La Poétique de L'espace, Presse Universitaire de France, Paris, 1957,pg. 15

${ }^{71}$ BRESSON, Robert. Notes sur le Cinématographe, Paris, Éditions Gallimard, 1988
} 
Já Buñuel ${ }^{72}$, em determinado momento de sua carreira, considerava como parte de seu objeto de criação, os sonhos que tinha como matéria primordial para escrever seus roteiros com Jean-Claude Carrière e depois filmá-los. Fellini ${ }^{73}$, como vimos anteriormente, resgatava personagens e histórias de sua infância para trazê-los à vida novamente em suas películas. Cada diretor busca entrar em contato com seu método pessoal, do qual o processo criativo deverá eclodir. Para alguns diretores, justamente, a criação não vai obedecer a nenhum método, seguirá aquilo que o diretor chama de intuição.

\section{6 - As etapas de realização e imbricações de uma etapa em outra}

Na maioria dos filmes de ficção, que pudemos observar ou ler a respeito, as etapas tendem a se consolidar com uma divisão mais ou menos nítida entre: escritura do roteiro; pré-produção; produção; pós produção e lançamento/ comercialização.

Para esta pesquisa, nos interessa analisar alguns dos movimentos criativos dos filmes A Via Láctea e Hotel Atlântico, relativos às seguintes etapas de produção: escritura do roteiro; pré-produção; produção e pós-produção, como os quatro principais momentos em que se concentram a maior parte dos movimentos criativos. Não tentaremos sistematizar o momento primeiro da concepção da idéia, por se tratar, como já foi visto de um terreno bastante incerto para se percorrer, inclusive para os próprios diretores. Mas buscaremos informações junto às diretoras Suzana Amaral e Lina Chamie sobre isso.

\footnotetext{
72 BUÑUEL, Luis. Meu ultimo suspiro, São Paulo, Cosac Naif, 2006 73 FELINI in SALLES, Cecília A. Gesto inacabado. Processo de criação artística, São Paulo, Fapesp/Anabluni,

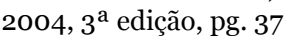


Na maioria das produções, a pré-produção costuma ter início uma vez o roteiro tendo sido finalizado. Isto se dá principalmente para que os recursos sejam otimizados, pois todo o trabalho da pré-produção será feito em cima do roteiro elaborado e mudanças implicariam em gastos desnecessários.

É comum, no entanto, que um roteiro tenha ainda que sofrer alguns ajustes durante a pré-produção, mas o ideal para equipe, mas sobretudo para a produção, é que este esteja o mais próximo possível da versão que será filmada. Quando o roteiro deve sofrer grandes modificações e a pré-produção está em andamento é um grande gerador de tensões para diretor, produtor e equipe. No Brasil, no ano de 2005, o filme Não Por Acaso $^{74}$ (2007) de Philippe Barcisnki se encontrava em pré-produção, com praticamente toda a equipe de filmagem contratada e trabalhando, quando chegou-se à conclusão que o roteiro apresentava falhas estruturais e que não poderia se iniciar as filmagens desta forma. A empresa produtora optou por paralisar os trabalhos da préprodução por tempo indeterminado, até que o roteiro fosse re-trabalhado para que desta forma se evitasse continuar com os gastos de parte do orçamento em algo que seria posteriormente refeito ou mesmo descartado.

Este exemplo nos mostra como existe um encadeamento lógico das etapas de produção em um filme. E também como muitas vezes, questões financeiras preponderam sobre questões criativas. No caso, a opção em se paralisar os trabalhos da pré-produção, acabou acarretando que alguns profissionais comprometidos com o filme, viram-se obrigados a buscar trabalho em outras produções que aconteciam na época, causando mudanças na configuração da equipe de filmagem. Além disso, podemos

74 BARCINSKI, Philippe. Não Por Acaso, São Paulo, O2 Filmes, 2007 
pensar no próprio tempo de espera, que pode ter trazido outros desdobramentos para a realização desta obra.

Da mesma forma que se espera o roteiro estar concluído para se iniciar os trabalhos de pré-produção, a filmagem inicia-se com o fim desta etapa precedente. Espera-se que as principais questões da pré-produção já tenham sido resolvidas, para que possa se iniciar as filmagens. Sem que haja, da mesma forma, desperdício de recursos, ou sem que seja necessário ficar à espera da resolução de questões relativas à fase anterior para que o filme possa andar. Não se trata apenas de recursos financeiros, no caso, pois questões pendentes durante a filmagem podem consumir demasiado os membros de uma equipe, gerar tensões desnecessárias e mesmo desconcentrar as pessoas que devem ter toda a atenção voltada para as filmagens em andamento.

Normalmente, um filme conta ter as locações principais aprovadas, elenco definido e parte dos cenários adiantados para que possa ter início a filmagem. Pode acontecer, que em algum momento durante a pré- produção, se decida por adiar o início das filmagens, caso não se consiga resolver de antemão algum destes quesitos apresentados.

Entre a montagem e a filmagem as fronteiras algumas vezes são mais tênues. Atualmente com as facilidades que as mídias digitais apresentam, existem diretores que gostam de verificar algumas possibilidades de montagem a partir de seu material captado já durante o período das filmagens, chegando ao ponto de ficarem no próprio set de filmagem com um computador onde podem ir trabalhando a partir do material filmado no próprio dia, em algum intervalo que encontram entre a preparação de um plano ou uma montagem de luz. 
Isso pode acontecer mesmo quando o filme é rodado em película, utilizando-se as fitas do vídeo assist ou mesmo o copião digitalizado. Muitas vezes também o material começa a ser organizado paralelamente pelo montador ou por um assistente de montagem enquanto as filmagens estão correndo. Acredita-se que tal procedimento possa ajudar a adiantar o trabalho relativo à fase da montagem, para depois quando o diretor se liberar das filmagens, poder discutir com o montador com este tendo visto já o material.

Um exemplo de como intercalar a montagem com as filmagens pode interferir no curso do processo de realização de um filme se deu durante as filmagens de A Via Láctea, de Lina Chamie em 2005. O material filmado em mini-dv foi sendo arquivado nos $H D s$ durante as filmagens. Ao passo que o material ia sendo carregado no $H D$, a diretora ia assistindo a algumas cenas depois do set. Pelo fato de ter acesso a este material, a diretora decidiu re-filmar uma das cenas que havia sido rodada ainda nas primeiras semanas de filmagem, em uma diária extra no final das filmagens, pois sentiu que não tinha atingido o que gostaria em sua filmagem original. A cena não pode ser reproduzida em sua locação de origem, pois se tratava de uma casa locada para o filme e já havia sido devolvida aos donos. A diretora de arte propôs utilizar um quadro que estava no cenário como fundo para se rodar novamente a cena, na qual a atriz dançava frente à câmera. E a diretora modificou um pouco sua decupagem, utilizando planos mais fechados para que pudesse filmar, sem denunciar esta mudança de locação. Desta forma, o fato de ter iniciado um pensamento sobre a montagem ainda durante as filmagens, permitiu à diretora intervir, ainda em tempo, no curso de seu filme e refazer uma cena da forma que achava mais eficiente. 
Já as outras etapas da pós produção como edição de som, mixagem, marcação de luz, entre outros, tendem a esperar que o filme esteja montado para que sejam iniciadas. Entretanto, um pensamento sobre a edição de som do filme indicado ainda no roteiro, pode ser de grande auxílio e trazer demandas para a filmagem. É comum que diretores peçam aos editores de som que enviem algum som específico para o montador, ainda em fase de montagem, com o intuito de verificar a eficiência de um corte. Músicas costumam ser usadas durante a montagem, mesmo que de maneira provisória. Em A Via Láctea, a montagem de imagem só poderia ter sido feita com a adição dos sons indicados já no roteiro, como veremos em detalhe, na análise deste filme. Aqui, as fronteiras mais uma vez entre as etapas se tornam tênues.

\section{7 - A Viabilização do Projeto}

Em relação à produção cinematográfica, quando refletimos sobre a poética de uma obra, como esta sendo fruto de uma época e de um contexto histórico, não podemos menosprezar como as questões relativas ao financiamento de um filme trarão implicações práticas, em todas as etapas de produção.

"O artista não é, sob este ponto de vista, um ser isolado, mas alguém inserido e afetado pelo seu tempo e seus contemporâneos. O tempo e espaço do objeto em criação são únicos e singulares e surgem de características que o artista vai lhes oferecendo, porém se alimentam do tempo e espaço que envolvem sua produção."75

"É importante ressaltar que a mera constatação que a influência do contexto não nos leva ao processo, propriamente dito. O que se busca é como esse tempo e espaço, em que o artista está imerso, passam à pertencer à obra." 76

Dentre fatores que influenciam a realização de um filme, podemos citar o modelo de financiamento estabelecido em nossos tempos. A forma como recursos são

75 Bakhtin in SALLES, Cecília A. Gesto inacabado - Processo de criação artística, São Paulo, Fapesp/Anabluni, 2004, $3^{a}$ edição, pg. 38

76 Ibid,. 38 
trazidos para a produção de uma obra cinematográfica irá condicionar inúmeros desdobramentos e possibilidades da criação.

Sobre um dos modelos atuais de financiamento de filmes no Brasil, devemos reter dois fatores, a necessidade de se apresentar um roteiro que justifique a existência da obra e o fato de este roteiro estar vinculado a um orçamento, também apresentado e aprovado por órgãos governamentais para que se possa captar recursos.

A obrigatoriedade por um roteiro e orçamento detalhado implica em um aprofundamento da fase inicial do projeto, seja em sua conceituação, seja no desenvolvimento do roteiro. A elaboração de um orçamento compatível com a obra requer que se conheça algumas de suas características e parâmetros que esta irá apresentar.

Normalmente, diretores brasileiros encontram-se já vinculados ao projeto nesta fase em que buscam recursos, muitas vezes sendo eles próprios a desenvolver o roteiro. Em geral, para a realização do orçamento, contam com a participação de um produtor executivo. Para os diretores que pretendem trabalhar seguindo um método de improviso, ou que busquem maior abertura em suas obras, como por exemplo, escrever o roteiro enquanto se filma, o roteiro escrito tem um caráter meramente burocrático. Mas mesmo nestes casos, pensamos que vivenciar esta escrita, pode deixar marcas no desenvolvimento do projeto.

Estes, entre outros, são alguns dos fatores ligados a questões financeiras da obra, que repercutem em sua realização como um todo. Sempre existirão as obras que fogem à regra e que busquem meios diversos de se financiar. E existirão também cineastas que trabalham de forma completamente independente e artesanal. No entanto, podemos considerar o cinema de ficção como uma arte que depende de recursos financeiros de 
grande porte, o que determina que haja um mínimo de planejamento para execução de um filme.

\section{8. - As diversas imagens do cinema}

Desvendar o processo criativo de uma obra pode suscitar ainda mais interesse a partir do momento que vivenciamos estas questões e podemos observá-las como problemas que tocam outros realizadores. As questões levantadas em um dado momento por um realizador podem se tronar respostas ainda que tardias, para questões que nós mesmos enfrentamos. Ou se tornar premonições de nossos próprios confrontos em nosso movimento criativo. Trazemos abaixo um relato sobre como estas questões relacionadas ao fazer podem surgir no âmbito do processo de criação. Ao observar e refletir sobre os caminhos da criação, enquanto as obras são realizadas, abrimos um diálogo com outras obras e seus processos criativos.

Ao realizar meu primeiro curta-metragem, constatei que existiam dois filmes que se referiam à mesma coisa; um construído por imagens mentais, com as quais vinha convivendo nos meses que antecederam sua realização e outro que se concretizava a cada tomada rodada. Não eram necessariamente, filmes diferentes, mas também não eram iguais. A distância entre um e outro se dava, principalmente pelo fato de que a realidade não consegue reproduzir a imaginação que a antecedia, em todos os seus aspectos e também por haver lacunas que a imaginação não havida dado conta de preencher. A obra se modificava em seu processo de construção, o filme enquanto um acontecimento, reescrevia o filme projetado, em seu estado de devir.

O filme que se concretizava era fruto, de um longo trabalho de planificação e agenciamento de diversos elementos que vieram a compor o mesmo. Porém este 
primeiro embate com o fazer, ficou claro que a partir do momento em que a câmera era ligada e os atores estavam em cena, algo escapava das mãos do controle, das minhas mãos como realizadora e de uma certa forma das mãos de toda a equipe. Todos passavam a ser regidos em maior ou menor grau pelo imponderável.

Atores deviam reagir uns aos outros, a câmera deveria seguir a movimentação dos atores, assim como o microfone aéreo, o restante da equipe no set não deveria se mover ou produzir qualquer barulho externo à cena e todos ali presentes, sintonizados, deveriam seguir realizando suas tarefas técnicas, entre anseios e ansiedades, até se ouvir a palavra corta. Tudo, a qualquer momento, poderia dar errado ou dar certo, mas sobretudo, a todo momento algo único estava sendo produzido.

A título de exemplo, descrevo aqui uma tomada na qual o ator deveria abrir uma lata contendo pó de café e simular que derrubava um pouco na mesa, sobre a qual apoiava os utensílios com os quais prepararia o café. Durante a tomada, no entanto, o ator encontrou dificuldade para abrir a lata e quando conseguiu, o café que estava dentro se espalhou por toda mesa e por seu braço. $\mathrm{O}$ ator reagiu nervosamente durante a tomada, recuperando todo o pó que podia e recolocando dentro da lata. Ao realizar estes movimentos, ele não saiu de seu personagem, continuou agindo como se estivesse em cena e decidi por deixar o plano se desenrolar, até que chegasse no ponto em que ele poderia retomar a ação que inicialmente estava prevista, o que de fato ocorreu. Nestes momentos em que o controle sobre a ação escapou de nossas mãos, cada membro da equipe precisou agir dentro de sua função, de modo a contornar o imprevisto e ainda assim, garantir a qualidade técnica da tomada, uma vez que esta não foi cortada. $\mathrm{O}$ nervosismo do ator em cena, acabou conferindo uma outra nuance para sua atuação, que 
posteriormente foi mantida na montagem, acrescentando certa comicidade desejada à cena.

Nas etapas que antecederam o momento da filmagem, tentou-se cercar cada detalhe relativo à sua execução. Mas a realização deste mesmo filme foi também permeada por uma série de circunstâncias, que se somaram ao longo de todo este processo, muitas destas, produzidas, outras, agregadas pelo acaso. O que nos leva a inferir que a realização de uma obra é um processo singular, a junção entre o que o artista almeja realizar e o que se produz de fato, como acontecimento.

Se no início, havia esta visão única, formada pelas imagens mentais iniciais, que deram origem às palavras do roteiro, ao longo do processo, à medida que outras pessoas eram agregadas à equipe, outras visões se somavam, traduzindo-se em ações dentro de cada área de atuação de cada um destes novos integrantes.

Durante este processo me deparei com um outra questão acerca da realização cinematográfica; a criação coletiva. $O$ que nos coloca como problema permanentemente, a necessidade de comunicar e traduzir as imagens que são mentais em alguma forma palpável entre os diversos membros de uma equipe.

À esta altura, como diretora, me dava conta de que já não existia um filme e sim, diversos. Um filme diferente para cada participante da equipe, que projetavam suas próprias imagens mentais a partir deste único roteiro que liam. O diretor deve conseguir seguir convivendo com o filme que projeta em sua mente e com as idéias trazidas por cada um dos integrantes de sua equipe.

Como parte do processo pedagógico deveríamos seguir, na realização destes pequenos curtas-metragens, uma série de regras criadas pelos professores do programa de Cinema e Vídeo da Escola de Comunicações e Artes: cada aluno deveria realizar 
pelo menos por uma vez; todas as funções definidas pelos professores; o filme poderia ser feito no estúdio do prédio de Cinema e Vídeo ou em qualquer locação situada dentro do Campus da Universidade; deveríamos seguir um cronograma de realização que compreendia todos os filmes; cada realizador contaria com 300 pés de negativo $16 \mathrm{~mm}$, não podendo dispor de mais do que isso, mesmo que quisesse comprá-los com recursos próprios e o equipamento a ser utilizado deveria ser o da Universidade.

Conforme as escolhas eram feitas e opções eram deixadas para trás, o filme, à sua maneira, tomava suas proporções, com o que era mantido e com o que era descartado. Nesta etapa da realização, da pré-produção, esta pequena obra em andamento ainda parecia algo abstrato, o filme formado pelas imagens mentais não havia sido tocado de fato por todas as interferências e decisões que estavam fora, aquelas que de fato condicionavam o filme ao que ele seria depois de rodado.

O primeiro verdadeiro confronto entre estes dois filmes se deu no momento em que o cenário ficou pronto. Não era a cozinha que havia sido imaginada no momento da escrita do roteiro. Mas era real. E por este motivo, superava todas as expectativas do que estava na idéia ou no papel. Além do quê, pode-se dizer que no roteiro, não haviam muitas especificações de como deveria ser esta cozinha, apenas o que ela deveria conter para o desenrolar da cena.

Como foi dito, uma das regras criadas como pressuposto para realização dos curtas metragens era de que os filmes deveriam ser realizados em locações dentro do Campus da Cidade Universitária, ou construídos no estúdio da ECA. Optamos por adaptar uma locação. Pelo fato de termos nos decidido por uma cozinha pré-existente em um prédio da Universidade, os móveis e instalações possuíam anos de uso, estavam gastos, suas marcas carregavam uma história que era contada em suas aparências. Isso 
interessava ao filme, naquele cenário, estavam materializadas as escolhas que haviam sido feitas semanas antes, de forma abstrata. Eu, com minha equipe, havíamos nos pautado por estas razões citadas para escolher uma cozinha pronta; desgaste, uso, aparência de objetos "vividos", mas o resultado, mesmo que suposto, diante dos nossos olhos, nos dizia claramente de que maneira iriam se inserir no filme que seria rodado ali. A cozinha escolhida, com seu aspecto, condicionava algumas informações que seria passadas ao espectador sobre os personagens que viveriam ali; eles seriam pessoas que habitam uma casa modesta, sem grandes arroubos na decoração e em alguns aspectos, levemente desleixados. Não possuíam objetos novos, pareciam usar seus utensílios até que não servissem mais, em suma, não demonstravam opulência. A cozinha, no entanto, era organizada e funcional.

A escolha da locação foi pautada por uma série de informações que a imagem desta locação nos trazia. Informações estas que nos diziam respeito ao gosto pessoal dos personagens, seus hábitos, o poder aquisitivo ou a que classe da sociedade pertencem. Claro que tudo isso é dito, presumidamente, com base em uma leitura pautada por conceitos que criamos e utilizamos ao interpretar o que é visto. Mas podemos dizer que um filme busca dialogar com estas outras imagens mentais que habita cada um dos espectadores?

A cozinha escolhida era uma das poucas cozinhas dos prédios da Cidade Universitária que podia ser interpretada como uma cozinha de uma casa. Também o tipo de piso, com um acabamento datado, traziam como informação visual o tempo de existência desta construção. Na maioria deles, encontramos cozinhas tipo industrial, ou nas quais os detalhes da arquitetura denotavam ser parte de um edifício não residencial. Alguns objetos como a pia pequena e armários instalados nas paredes conferiam a esta 
cozinha coletiva o ar residencial que buscávamos. Algumas adaptações foram necessárias, como esconder as janelas que seguiam o padrão do prédio, por uma tapadeira $^{77}$, no mesmo padrão de azulejo das outras paredes. Para a equipe, o filme se materializou uma primeira vez quando este único cenário que o filme teria ficou pronto, incorporando a história de um lugar existente, acrescido destas adaptações necessárias. Estávamos diante de uma cozinha, com detalhes que iam desde as paredes envelhecidas, até restos de farinha na pia e cascas de ovos no lixo. O que quer dizer que este ambiente possuía "vida", ou nos fazia crer que alguém vivia ali. Fator que considerávamos de importante para que uma história fosse contada ali. E sabemos, que para muitos atores também é fundamental interagir com o espaço no qual deverão atuar. Subitamente, a decupagem feita anteriormente em uma folha de papel, podia ser visualizada no espaço em que nos encontrávamos, com a ajuda de um visor de diretor. Por este motivo, foi possível, um dia antes da filmagem, ainda fazer alguns ajustes aos planos que havíamos desenhado, alterando planos pré-concebido, e com o qual havíamos imaginado sem nos dar conta de que de fato, algumas coisas não funcionariam no espaço real, mas apenas no papel.

Considerando a engrenagem de produção de um filme, as decisões previas tornam-se determinantes para que o filme avance e novas escolhas possam ser feitas. Através de uma cadeia de decisões, os elementos foram, um a um, se somando e se subtraindo, ao longo deste processo de feitura do filme. O processo de escolhas se estendeu ainda durante a montagem, a edição de som e a mixagem. As decisões tomadas resultaram como o consenso entre o que se buscava, o que se apresentou como possibilidade e o que foi modificado pelo acaso.

77 Parede falsa feita de madeira, comumente utilizadas em cenários. 
Em todas as etapas concluídas, o filme real se modificava em relação ao filme imaginado. Mas por outro lado, se aproximava. O filme real era a versão atualizada das primeiras imagens mentais que surgiram, era o resultado de todos os embates travados, as escolhas, renúncias e até mesmo do improviso. Era o que mais se aproximava do filme imaginado, aquele que não pode de fato ser tocado, que permanece encapsulado na memória e que já não importa, pois aquele que está vivo no mundo, é o filme possível. Por outro lado, o filme imaginado está contido neste filme que existe para o mundo. Aquela primeira idéia que se transformou em roteiro, que serviu de base para as filmagens, foi o ponto de partida para o que buscávamos realizar, enquanto concretizávamos o filme que existe. O filme imaginado é uma versão do filme real, e não o contrário. Cada membro da equipe imaginou seu próprio filme ao ler o roteiro e o filme real é a soma de todas as escolhas, concretizadas durante sua realização. E claro, daquilo que também não se realizou e que não faz parte do filme, mas de seu processo.

Com este primeiro exercício de faculdade, intitulado Dia de Glória ${ }^{78}$, pude me aproximar deste processo feito de escolhas que é o da realização cinematográfica. Quando Jacques Aumont, em A Teoria dos Cineastas $^{79}$, se refere ao diretor cinematográfico, ele afirma que o cineasta é um artista que trabalha sobretudo com seu pensamento. Tal afirmação se deve ao fato de que, no cinema de ficção, de modo geral, o cineasta convive muito mais tempo com o projeto de filme, do que com a própria filmagem. Depois de ter o filme rodado, também convive um longo tempo com o filme em segmentos, até se chegar ao corte desejado. Desta forma, seu processo é sobretudo mental, no qual ele busca antecipar resultados para suas possibilidades de escolhas.

\footnotetext{
78 GONÇALVES, Carolina. Dia de Glória, São Paulo, ECA - USP, 2002

79 AUMONT, Jacques. A Teoria dos Cineastas, Papirus, Campinas, 2004
} 
Este prolongamento da fase que antecede a filmagem tem suas justificativas dentro do processo de realização. Os fins práticos da pré-produção, como levantamento e escolha da locação, casting dos atores, produção de objetos e figurinos ocorrem ao longo de determinado tempo. São, como vimos, pequenas concretizações destas escolhas. No entanto, durante toda esta etapa do processo de realização, a convivência que o diretor tem com seu filme é principalmente mental.

No âmbito da criação, o processo modifica não somente a obra, mas também o artista. O processo é responsável por que se chegue à outra margem transformado, sendo o início desta travessia as imagens mentais e no outro extremo, a obra pronta. A obra se desprende do artista em determinado momento, ganha o mundo e assume a vida que lhe é destinada. $\mathrm{O}$ artista pode continuar a se alimentar deste processo e de como sua obra é recebida e afeta outras pessoas. Se ao longo da realização de um filme, o artista tem a chance de modificar a obra com suas escolhas, no caso do cinema, ela não se modifica mais a partir da cópia finalizada ${ }^{80}$.

Em certos aspectos, o processo de criação pode ser mais valioso para o artista do que a obra pronta. Todo aprendizado, vindo da realização de uma obra, deve servir para um próximo trabalho, uma próxima realização.

\footnotetext{
80 Atualmente, com os recursos tecnológicos disponíveis, os custos de alteração de uma cópia final diminuíram consideravelmente, permitindo-se que sejam efetuadas modificações mesmo após a conclusão do filme.
} 


\section{DOIS PROCESSOS CRIATIVOS}

\section{1 - Estudos de Caso}

Ao propormos análises contíguas dos processos de realização dos longasmetragens de A Via Láctea e Hotel Atlântico busca-se enfatizar em cada processo o que pareceu mais relevante como modo de atuação das respectivas diretoras destes filmes.

Foram destacados aspectos relativos à realização do roteiro de ambas as obras, a direção de atores e métodos utilizado para tal, a abordagem de cada uma sobre a decupagem, assim como o processo de montagem de imagem e som. No caso de A Via Láctea, acrescentamos a análise de algumas estratégias desenvolvidas para a filmagem, que abarcava diversos elementos sobre os quais não se tinha qualquer poder de controle. Também em relação a este filme, pareceu pertinente que a análise da edição de som fosse realizada juntamente à montagem das imagens, pois, trata-se neste caso de um processo indissociável. No caso de Hotel Atlântico, a análise da escrita do roteiro, assim como o que toca a edição de som se deram em comparação ao romance do qual o filme foi adaptado, pois haviam muitos indícios na obra literária que poderiam explicar opções adotadas pela diretora.

Nestas reflexões, não se buscou criar um parâmetro comparativo entre os filmes, embora semelhanças e diferenças se sobressaiam. O objetivo de analisar estes filmes em conjunto é justamente ressaltar a singularidade do trabalho de cada uma das diretoras com a expectativa que possam vir a servir como uma base de dados para futuros estudos acerca de processos criativos, ou mesmo como inspiração para outros diretores. 


\section{2 - HOTEL ATLÂNTICO}

\subsection{1 - A concepção do roteiro de Hotel Atlântico}

Hotel Atlântico é o terceiro longa metragem de Suzana Amaral. Assim como os dois filmes precedentes, trata-se de uma adaptação literária, do romance homônimo de João Gilberto Noll ${ }^{81}$. A preferência de Suzana por adaptar romances para o cinema vem do fato de a diretora optar por trabalhar com narrativas previamente estruturadas ao invés de desenvolve-las. No caso de Hotel Atlântico, o roteiro, baseado no livro, é assinado também pela diretora.

Suzana Amaral ${ }^{82}$ afirma a importância do roteiro para seu trabalho: "tudo deve partir do roteiro." O que quer dizer, que ela vai tentar seguir o texto em todos os momentos de seu trabalho, tanto na filmagem, como na montagem. Ela considera que por ser o tempo de escrita um tempo no qual ela pode trabalhar sob menos pressão do que nas filmagens, as decisões são tomadas com mais clareza e bastante rigor, e, portanto quando surge uma dúvida durante o processo de filmagem, ela costuma recorrer ao que escreveu como um caminho do qual não quer se desviar. "Às vezes acontecem mudanças (no roteiro) durante a filmagem, mas é preciso pensar bem, pois se está ali, a cena deve ter alguma função importante na estrutura do filme." ${ }^{93}$ Suzana busca o entendimento do sentido e do sub-texto de cada cena, pois com isso, ela acredita, que tem menos chance de criar redundâncias ao longo do roteiro. Cada cena

\footnotetext{
81 NOLL, João Gilberto. Hotel Atlântico, São Paulo, Francis, 2004

82 AMARAL, Suzana, Depoimento durante as filmagens de Hotel Altântico, 2007

83 Ibid.
} 
tem uma função dentro da estrutura e a diretora não faz uso de duas cenas que tenham sentidos semelhantes, ao seu ver.

Para separar uma cena de outra, Suzana Amaral se atém à definição de cena no cinema, segundo a qual a cada mudança de espaço ou de tempo, considera-se uma nova cena ${ }^{84}$ Ao adaptar o romance de $\mathrm{Noll}^{85}$, a diretora não segue a divisão de capítulos que o livro propõem. Ela cria suas próprias subdivisões correspondentes às cenas, conforme a definição apresentada por Burch ${ }^{86}$. Esta é a primeira alteração que a obra literária ${ }^{87}$ vai sofrer, ao abandonar a estrutura proposta por seu autor.

A primeira pergunta que surge em relação à uma adaptação, é em relação à escolha da obra literária. Jean-Claude Carrière ${ }^{88}$ fala que a adaptação sempre oferece um ponto de partida, algo sobre o que se discutir, o que pode representar uma certa segurança em relação ao que se está fazendo, mesmo que o caminho seja proceder alterações para que o texto resulte em um roteiro para um filme. Segundo a diretora, o que faz com que ela opte por algum livro vem de uma empatia imediata com aquilo que leu. Usando suas palavras, no momento em que está lendo determinado livro, ela "já imagina um filme" ${ }^{\text {89 }}$. Segundo Suzana ${ }^{90}$, a partir das imagens sugeridas pelo texto, forma-se para a diretora a idéia de um filme, ou imagens mentais que ela traduziria em um filme. Como sugere Bachelard ${ }^{91}$, são as imagens do texto que criam eco no leitor e à partir destas imagens poéticas, do qual o leitor se apropria, é que se tem início o trabalho de recriação. Em outras palavras, um romance como ponto de partida para uma

\footnotetext{
84 BURCH, Noël. Práxis do Cinema, São Paulo, Perspectiva, 1992

85 NOLL, João Gilberto. Hotel Atlântico, São Paulo, Francis, 2004

86 BURCH, Noël. Práxis do Cinema, São Paulo, Perspectiva, 1992

87 NOLL, João Gilberto. Hotel Atlântico, São Paulo, Francis, 2004

88 CARRIÈRE, Jean-Claude. O Trabalho com o Roteirista e sua Relação com o Diretor in ESPINOSA, Júlio Garcia e outros. Simples Assim, Intermeios, São Paulo, 2012

89 AMARAL, Suzana, Depoimento durante as filmagens de Hotel Altântico, 2007

90 Ibid.

91 BACHELARD, Gaston. La Poétique de L’espace, Presse Universitaire de France, Paris, 1957
} 
adaptação tem de alguma forma o poder de aguçar a imaginação em termos de imagem e som.

Devemos lembrar que o processo criativo no tipo de filme sobre o qual nos debruçamos, é um processo que acontece em rede. Podemos considerar, desta forma, como sendo a leitura do romance que a diretora realiza o início desta criação em rede que se estende por todo o filme. De certa forma, todos os filmes de ficção que partem de um roteiro escrito, tratando-se de adaptações literárias ou não, passam por um processo de adaptação, ou de transposição das imagens sugeridas pelo texto para a imagem filmada. Sendo assim, um filme, que tem como base um roteiro escrito, está sendo adaptado constantemente ao longo de sua feitura. $\mathrm{O}$ que quer dizer que todo o processo de adaptação será realizado, não somente no momento da escrita do roteiro, mas ao longo de todo o filme, como por exemplo, na edificação de um cenário, na escolha de figurino e até mesmo pelo ator, ao compor seu personagem. Analisaremos exemplos observados em Hotel Atlântico mais adiante.

Jean-Claude Carrière ${ }^{92}$ reflete a respeito da questão da adaptação literária, dizendo que todo o problema reside nesta passagem efetuada, do escrito para as imagens. A passagem de um livro para um roteiro opera-se utilizando a mesma matéria, as palavras. Mesmo que haja a necessidade de se adequar a forma literária para uma forma mais cinematográfica da escrita, tanto um texto literário quanto um texto cinematográfico funcionam de acordo com as leis das palavras e são percebidas de uma mesma forma. O texto deixa espaço para a imaginação do leitor criar as imagens, conforme são descritas. Já o momento em que se opera a filmagem de um roteiro há

92 CARRIÈRE, Jean-Claude. O Trabalho com o Roteirista e sua Relação com o Diretor in ESPINOSA, Júlio Garcia e outros. Simples Assim, Intermeios, São Paulo, 2012 
uma cristalização de elementos na imagem da forma como foram arranjados. As cores, as nuances as texturas de uma imagem são dados concretos. A imagem filmada não deixa lacunas quanto ao que vemos.

Bresson $^{93}$ coloca o momento da escrita do roteiro como a morte de uma forma imaginativa que se pode ter de um filme. As primeiras imagens mentais relativas a um filme cederão lugar ao texto do roteiro, estruturado a partir de uma linguagem escrita. No caso da adaptação literária, esta morte também ocorre, pois o diretor projeta estas imagens a partir de sua leitura do romance. Mas deve torná-las escrita novamente ao roteirizá-lo.

Quando se pensa em adaptação de uma obra literária para o cinema, estamos falando de um processo de tradução intersemiótica, ou a busca de equivalências de um meio artístico em outro. Suzana Amaral, ao criar um filme a partir de uma obra préexistente, busca manter as funções poéticas do texto em outro meio.

Em A Palavra é o Chão da Imagem ${ }^{94}$, encontramos um exemplo ilustrativo para a forma como Suzana Amaral efetua a adaptação de um texto literário. A seguir, uma passagem da adaptação do romance $A$ Hora da Estrela $^{95}$ de Clarice Lispector, que Suzana Amaral levou às telas em 1985.

"O jogo de palavras se dá num dialogo entre Macabéa e Olímpico de Jesus Moreira, nordestino também, de jeito criado também, mas que se defendia das cáries com o sonho de virar gente importante, político, deputado.

'Metade da conversa, Olímpico se volta para Macabéa:

- Olhe Macabéa...

- Olhe o quê?

- Não, meu Deus, não é "olhe: de ver, é "olhe" quando se quer que uma pessoa escute! Está me escutando?

- Tudinho, tudinho!

- Tudinho o quê, meu Deus, pois se eu ainda não falei!'

93 BRESSON, Robert. Notes sur le Cinématographe, Paris, Éditions Gallimard, 1988, pg. 25

94 AVELLAR, José Carlos. Cinema e Literatura no Brasil, São Paulo, Câmara Brasileira do Livro, 1994

95 LISPECTOR, Clarice - A Hora da Estrela - Nova Fronteira, Rio de Janeiro, 1977 
No cinema, Suzana Amaral tirou algumas palavras do dialogo e acrescentou à anedota os gestos dos atores. No filme, Olímpico diz apenas "não é olhe de olhe, é olhe de olhe" e explica os diferentes sentidos da palavra variando o jeito de dizê-la." ${ }^{96}$

Neste trecho, Avellar tenta evidenciar como a diretora utiliza os recursos disponíveis na imagem, para encontrar esta equivalência entre a forma escrita e a forma filmada, acrescentando à primeira, a gestualidade dos atores. O intuito da diretora é manter um certo humor contido no texto e expressar a ingenuidade da personagem, que não consegue conceber um duplo sentido nas palavras utilizadas por seu interlocutor. Paul Valéry ${ }^{97}$ nos fala sobre o rearranjo do elementos agenciados segundo uma nova ordem, nunca antes imaginada. Neste caso, a ordem do romance deixa de existir e a narrativa se reorganiza, segundo a ordem das imagens e sons.

Em Hotel Atlântico ${ }^{98}$ podemos observar uma forte característica do cinema de Suzana Amaral, narrativas centradas em um único personagem, nas quais tudo é visto pelo espectador, sob o ponto de vista do personagem principal. É a maneira como este personagem está inserido no universo apresentado que propicia o desenvolvimento da narrativa.

Ao iniciar um roteiro, Suzana costuma seguir diretrizes estipuladas por ela mesma. Ao estabelecer para si quais são os parâmetros que regem seu processo criativo, de recriação do roteiro a partir da obra literária, Suzana Amaral, define qual a poética a ser empregada em sua obra, ou o programa operacional que vai guiá-la ao longo da feitura de seu filme.

96 AVELLAR, José Carlos - Cinema e Literatura no Brasil, 1994, pg. 110 97 VALÉRY, Paul. L'Invention Esthétique, In Oeuvres I, Paris, Gallimard, 1957

98 NOLL, João Gilberto. Hotel Atlântico, São Paulo, Francis, 2004 
De acordo com palavras da própria Suzana Amaral, ela busca separar as ações e diálogos dos personagens de descrições e reflexões presentes em um texto. À partir dos primeiros, a diretora vai estruturar seu roteiro. A segunda parte vai servir à diretora de subtexto, algo que terá igual importância ao longo de seu trabalho. Outra regra que ela sempre diz ter em mente: não deixar que os diálogos sejam a parte central em um filme.

Em Hotel Atlântico, ao reescrever as passagens do romance para o roteiro, Suzana Amaral, na maioria das vezes, não traz os diálogos citados no texto de base. Seu trabalho costuma se limitar a descrever as ações que apareceram no romance e estruturar a cena partir disto. A não transcrição dos diálogos trará uma implicação na forma como ela conduz a direção de atores, como veremos a seguir.

Estas qualidades que ela destaca ao roteirizar um romance, não necessariamente devem estar presentes no texto literário escolhido, mas são princípios que ela segue para estruturar o roteiro de maneira equilibrada. Amaral acredita que o filme não deve dizer, deve mostrar. Ela entende que o dialogo tem uma função precisa, mas não deve se sobrepor à imagem. Ou como ressalta Viktor Chklovski em um texto no qual discute as influências trazidas pelo cinema à literatura: "No cinema, não se conta nada, se mostra tudo." 99

Suzana Amaral afirma ${ }^{100}$, em relação a Hotel Atlântico ${ }^{101}$, que ao transpor a obra literária para o cinema, ela tinha em mente manter dois aspectos que o livro apresentava: a desconexão entre os eventos da narrativa e a estranheza provocada pelo romance. Quanto à narrativa do livro, apesar de esta ser linear, existe pouca relação de

\footnotetext{
99 "Au cinema, on ne raconte rien, on montre tout." CHIKLOVSKI, Viktor - Littérature et Cinématographe In Résurrection du Mot , Paris, Éditions Gérard Lebovici 1985 ,t.n. pg. 138 100 AMARAL, Suzana. Depoimento em 29/10/2015

101 AMARAL, Suzana. Hotel Atlântico, São Paulo - Roteiro Cinematográfico, 2007
} 
causa e efeito entre os acontecimentos. Toda história é contada do ponto de vista de Alberto, personagem principal e narrador, os eventos são todos de ordem realista, que beiram situações absurdas, no entanto passíveis de se sucederem. A fragmentação, no entanto, não está na ordem dos fatos, mas sim na desconexão entre eles. Suzana fala: "Tudo vai se passando sem ter um por quê. E na maioria das vezes, no cinema, esperase que tudo tenha uma razão para estar acontecendo. Acho que foi essa falta de explicação para as coisas que me interessou em primeiro lugar neste livro."102

Sobre a estranheza, ela comenta é algo intrínseco à obra de Noll. No caso de Hotel Atlântico ${ }^{103}$ esta falta de causalidade gera uma expectativa sobre os acontecimentos, e as situações que sucedem, os personagens que surgem na história e como o protagonista reage a todas estas informações são sempre inusitados. E segundo Suzana, existe um subtexto muito forte nesta obra, dado que ela considera a base de uma conversa para realizar a direção de atores. Ela afirma que tentou transpor o estranhamento que o livro provocava em todos os aspectos relativos ao filme: na escolha das locações, no figurino e até mesmo na escolha dos figurantes.

Hotel Atlântico ${ }^{104}$ é um romance narrado em primeira pessoa, o que sugere que tudo que está sendo descrito é filtrado pelo protagonista. Ele está presente em todas as passagens do livro. Não há espaço, neste livro, para uma segunda voz. Mesmo os diálogos de outros personagens são reproduzidos pela voz do protagonista, todas as falas são reditas por Alberto e aparecem como parte do que ele descreve nesta narrativa em primeira pessoa. Portanto tudo que é visto e ouvido, passa pelo filtro deste

102 AMARAL, Suzana. Depoimento em 29/10/2015

103 NOLL, João Gilberto. Hotel Atlântico, São Paulo, Francis, 2004

104 Ibid. 
personagem, o que sugere grande subjetividade em todas as informações que chegam ao leitor.

Das diversas leituras que este romance proporciona como caminhos para uma adaptação, o tratamento dado ao filme Hotel Atlântico busca reproduzir um universo naturalista, colocando o espectador sempre como um elemento externo à narrativa, no papel de um observador. O espectador acompanha o personagem em sua trajetória. Como o leitor fica sabendo de tudo através Alberto, ao transpor esta narrativa para o cinema, Suzana Amaral optou por fazer com que este personagem esteja em todas as cenas. Em poucos momentos se recorreu ao uso de uma câmera subjetiva. O espectador assume um papel voyer em relação ao personagem principal. Em relação ao romance, podemos dizer que se trata de um recurso que não reproduz exatamente o recurso literário empregado por $\mathrm{Noll}^{105}$, no qual o espectador partilha de seus pensamentos. No filme, o espectador observa as ações de fora.

Tudo que se passa no filme conta com a presença de Alberto, o que faz com que o espectador saiba a mesma coisa que ele. Não existe no filme ou no roteiro nenhuma informação que o espectador saiba de antemão ou antecipações do que pode vir a acontecer, recurso comumente empregado no cinema. Esta determinação da diretora faz com que o filme tenha um registro realista dos fatos e o uso da linguagem cinematográfica é empregado desta maneira. O som tenta reproduzir o que a imagem nos mostra e a montagem é utilizada para privilegiar a mise-en-scène, não havendo uso de montagem paralela ou de avanços e retrocessos no tempo. Com exceção de um único momento no final do filme, a narrativa reproduz os fatos como estes são apresentados no livro.

105 NOLL, João Gilberto. Hotel Atlântico, São Paulo, Francis, 2004 
Alguns caminhos para a adaptação se mostram mais evidentes nesta tarefa, outros vão surgir das necessidades específicas do meio para o qual está se traduzindo, no caso o cinema.

O cinema de Suzana Amaral é um cinema principalmente pautado pelo ator. É à criação dos personagens em conjunto com seus atores que Suzana dedica sua maior atenção ao realizar um filme. Na transposição dos dois personagens mais importantes do livro para o filme, Suzana não seguiu a risca o que o romancista criou em termos de características físicas dos mesmos. O personagem principal, Alberto, no livro é descrito como um homem de 40 anos, portanto, mais velho do que Júlio Andrade, o ator escolhido para interpretá-lo, que à época das filmagens tinha 32 anos.

\section{“1. EXT. RUA CENTRO URBANO SANTOS - FIM DE TARDE}

ALBERTO(30/35 anos) caminha pela calçada estreita. Um vento frie, fora de época, faz com que ponha as mãos no bolso."106

Chama a atenção que a única descrição sobre Alberto nesta cena seja sua idade, fator pouco relevante para o andamento do filme. No entanto, no livro a informação é de que o personagem conta já com 40 anos. "Estou velho, pensei. Mal chegado aos quarenta, velho." ${ }^{107}$ No livro, a idade do personagem seria uma das justificativas para a crise na qual este se encontra. Já no filme, esta informação acaba por não trazer nenhuma conseqüência. Havia apenas o receio de que leitores do roteiro que conhecessem o livro imaginassem o protagonista com outra idade. A modificação da idade do personagem, foi feita para tornar a idade do personagem mais compatível com a idade do ator que iria interpretá-lo.

106 AMARAL, Suzana. Hotel Atlântico, São Paulo - Roteiro Cinematográfico, 2007

107 NOLL, João Gilberto. Hotel Attântico, São Paulo, Francis, 2004, pg. 19 
Já o personagem de Sebastião, aparece pela primeira vez no romance com a seguinte descrição: "a filha do cirurgião chamou depressa Sebastião, o enfermeiro negro $(\ldots))^{\prime 108}$

Sebastião foi interpretado pelo ator João Miguel, que também não condiz com a descrição do personagem por Noll. Outro exemplo são os personagens de Nelson e Léo, que aparecem sempre juntos, sendo Nelson descrito como um tipo bem louro, e Léo como moreno. No filme temos Jiddu Pinheiro, que é moreno, interpretando Léo e André Frateschi, de pele mais clara e cabelo clareado na época do filme, interpretando Nelson. Há uma inversão entre as características físicas dos dois, porém mais uma vez, encontramos a equivalência entre livro e filme quando atentamos às características psicológicas de cada personagem.

A opção por não se manter fiel neste momento se deve principalmente à escolha dos atores para os papéis. O que nos leva pensar na hipótese de que o que ela estava buscando não era a fidelidade absoluta às imagens do texto, mas ao seu significado. Se tornou mais importante para a diretora a construção que ela elaborou para seu filme, do que o romance em si. Este foi apenas um ponto de partida para sua criação.

Se atentarmos para a personalidade dos personagens Nelson e Léo, veremos que existe uma busca pela fidelidade, na passagem do romance ao filme, mesmo que características físicas não tenham sido respeitadas. Em parte podemos alegar que se trata do trabalho do ator, da composição de personagem e que o ator deve ter condições de criar vilões ou mocinhos, jovens ou velhos. Mas, podemos nos perguntar se o

108 NOLL, João Gilberto. Hotel Atlântico, São Paulo, Francis, 2004, pg. 75 
trabalho do diretor não é justamente observar um ator e selecionar as características de personalidade que melhor podem servir a um papel ou a outro.

Passamos a considerar as escolhas de Suzana Amaral em não se manter fiel, em todos os aspectos ao romance, sob o prisma de que no universo da escrita, o personagem pode ser inventado da maneira que o autor deseja. Já no caso do cinema, o personagem será um misto entre a escolha do diretor por um ator, o que o ator é e o que ele conseguiu criar pensando naquele personagem em questão. $\mathrm{O}$ autor de um livro de ficção, parte unicamente de sua imaginação. Já no cinema, os elementos devem ser escolhidos a partir de um leque de opções.

Outras formas de se traduzir o romance encontradas no filme dizem respeito à fotografia e ao som e como estes com recursos próprios do cinema Suzana Amaral e sua equipe encontram formas de expressão que sintetizaram esta passagem do romance ao filme. O texto narrado em primeira pessoa insinua, que em sua forma cinematográfica, o espectador pode ser colocado no ponto de vista e escuta do personagem principal, através do recurso da câmera subjetiva e de uma edição de som que busque reproduzir uma determinada percepção sonora. Apesar de Alberto estar presente em todas as cenas do filme, a câmera se coloca no ponto de vista de um observador. No entanto, a opção por uma câmera subjetiva é reservada apenas para alguns momentos específicos do filme, no qual a tradução literal de uma ação do romance não seria possível.

Na passagem do filme em que o personagem Alberto acorda no hospital, seu estado é descrito da seguinte maneira: "Mesmo com a minha cabeça nublada, deu para notar que ele sorria com empolgação." ${ }^{109}$ Nesta passagem, temos uma câmera que assume completamente o ponto de vista deste personagem. Trata-se de uma câmera na

109 NOLL, João Gilberto. Hotel Atlântico, São Paulo, Francis, 2004 - pg. 73 
mão, que treme e se movimenta, seguindo movimentos que poderiam ser realizados pelo corpo do ator. A câmera é posicionada da mesma maneira que o ator se encontra, em um leito hospitalar e aponta para partes do corpo do ator como se de fato fossem seus olhos tateando neste ambiente de maneira insólita. Além disso, a imagem possui momentos de desfoque, o que parece ser uma boa tradução imagética para a expressão "cabeça nublada" que o autor do livro criou. Neste momento, a edição de som também contribui para acentuar esta presença da câmera subjetiva, colocando a respiração ofegante do personagem em primeiríssimo plano. Ouvimos a voz do médico que fala com ele, ruídos que o próprio convalescente provoca ao se debater na cama, mas não temos referências de sons externos, o que traz o espectador para muito próximo do personagem.

Em outro momento do filme a diretora faz novamente apelo a estes recursos sensoriais como forma de tradução intersemitótica das descrições de Alberto. No livro temos as seguintes passagens:

“...foi assim que eu fui caindo, e enquanto eu desmoronava a primeira coisa que senti foi que eu ia perdendo a audição - e quando o meu corpo inteiro se espatifou na laje do banheiro eu já estava completamente surdo. Eu via muito bem, via perfeitamente a expressão de Sebastião debruçada sobre mim, mexendo com a boca, me falando coisas que eu não conseguia mais ouvir" 110

Nesta seqüência, mais uma vez, tem-se a presença dos personagens reforçada pelo som da respiração se sobressaindo na edição de som. Trata-se de uma seqüência de três cenas em que os personagens Alberto e Sebastião estão no início dentro de um quarto de hotel, depois que Alberto vai ao chão, Sebastião o pega no colo e o leva por um caminho até a praia, senta-o ao seu lado, e ficam olhando o mar. A partir do momento em que Sebastião começa a levar Alberto no colo para a praia, começamos a

110 NOLL, João Gilberto. Hotel Atlântico, 2004 - pg. 105; 106 
ouvir o som da respiração destes, mas ainda existem elementos realistas na trilha sonora, como passos e o som do mar. Durante o trajeto, a câmera simula outra vez o ponto de vista de Alberto, a imagem é mostrada de cabeça para baixo e trata-se de uma câmera na mão, fazendo-se sentir a movimentação de alguém sendo carregado no colo por outra pessoa que caminha na areia. No momento em que Alberto está sentado ao lado de Sebastião na praia e vai desvanecendo, o som do mar, que é bastante presente até então, vai desaparecendo, deixando apenas a respiração de Alberto audível. Esta escolha da diretora mostra de que maneira, no cinema, se dá a criação em rede. A concepção de um movimento de câmera pode ser feita pelo diretor, mas será executada pelo diretor de fotografia ou operador de câmera, que irá imprimir suas marcas, junto com os atores. O trabalho de cada um dentro de filme, por natureza mais diversa que possa se ter, está no final, interligado no objeto filme. A colaboração entre os diversos criadores é essencial para a coerência da obra.

Existem elementos que ao se escrever um livro não precisam ser pensados, mas, que ao se transpor o mesmo conteúdo para um filme, precisarão ser elaborados, acrescentando-se ou suprimindo detalhes que não estavam no texto. Em Hotel Atlântico o romancista não precisou dar um nome ao hospital onde o personagem ficaria internado. Ele fez descrições do que o personagem principal via em seu quarto, nos arredores e corredores e outros personagens que povoavam aquele local e tudo isso foi suficiente para que o leitor compreendesse aquele ambiente.

"Eu via sim, isso eu conseguia fazer o tempo todo em que me mantinha acordado: via o Sagrado Coração de Jesus na minha frente, via imagens de pessoas que vinham olhar o artista sem a perna, via a careca lustrosa do Dr. Carlos, e em certas ocasiões lamentei não ter perdido além da perna, a vista." 111

${ }^{111}$ NOLL, João Gilberto. Hotel Atlântico, 2004 - pg. 78 
No filme vemos em um dos planos em que os protagonistas estão na sacada deste hospital, onde está pendurada uma placa com o nome do mesmo. Não é um detalhe que se sobressaia na imagem, mas que a compõem. No entanto trata-se de um detalhe necessário, como informação que torna verossímil aquela imagem. Foi uma opção proposta pela direção de arte, para reforçar a associação da fechada com o interior do hospital na trama. O nome escolhido para o hospital veio da referência trazida pelo próprio texto: Hospital Sagrado Coração de Jesus. Este tipo de solução mostra uma ação conjunta entre direção e direção de arte, reiterando a hipótese de que a adaptação não segue um caminho único para acontecer, quando pensamos na criação coletiva, como no caso do cinema.

A propósito de reflexões que autores como Chklovski ${ }^{112}$ e Avellar ${ }^{113}$ nos trazem sobre, a influência mutua das artes, encontramos no romance uma passagem que poderia ser considerada como uma influência cinematográfica direta sobre o estilo da escrita. Esta passagem assemelha-se ao um recurso de montagem do insert, e evidencia uma alternância rápida entre imagens, sem que se saia completamente da cena, estabelecida como principal no ponto em que a narrativa se encontra. No livro temos a seguinte passagem, que transcorre enquanto o personagem Alberto se encontra em um quarto de hotel, ainda no início da narrativa:

"Olhei as horas: oito e meia. Me levantei com esforço, me doíam as pernas. Vesti o casaco. Fui até o banheiro me segurando pelas coisas, sentindo uma espécie de incapacidade - me veio a imagem de um doente em convalescença, se preparando para deixar o hospital." 114

Nesta passagem, Noll faz uso desta figura de estilo própria do cinema, ao sugerir a inserção de uma imagem mental descrita pelo personagem enquanto realiza

\footnotetext{
112 CHKLOVSKI, Viktor. Resurrection du Mot et Litérature e Cinématographe, Paris, Éditions Gérard Lebovici, 1985

113 AVELLAR, José Carlos. Cinema e Literatura no Brasil, São Paulo, Câmara Brasileira do Livro, 1994

114 NOLL, João Gilberto. Hotel Atlântico, 2004 - pg. 17
} 
uma outra ação. É curioso, que justamente neste ponto do romance em que a linguagem escrita mais se aproxima de recursos estilístico próprios do cinema, a diretora tenha optado por não mencionar esta passagem em seu filme. Vemos apenas Alberto que olha pela janela do quarto de hotel e então temos um corte para o personagem andando próximo a uma mureta do quebra-mar.

À primeira vista, esta imagem que antecipa o que ocorrerá posteriormente com o personagem, que de fato se transforma num doente que deixa o hospital à certa altura da narrativa, foi suprimida do filme para que não antecipasse elementos que deveriam ser guardados como surpresa para o espectador. Se no romance esta cena pode ser descrita como um flash ou imagem mental, no filme ele mostraria talvez mais elementos do que o desejado, não causando o mesmo impacto na hora em que estas imagens de fato fossem reveladas.

No filme, além desta escolha por não antecipar estes elementos, a diretora optou por inserir em seu filme, desde a escritura do roteiro, uma cena que não faz parte do romance e que no entanto é de extrema importância para o filme. Esta nova cena não corresponde à outra suprimida no livro mas podemos dizer que há uma equivalência quanto à função poética dentro da obra. Ela é responsável por gerar a ambigüidade na leitura que pode ser feita, do filme, podendo ser entendida como uma premonição.

Na nova cena, introduzida por Suzana Amaral, vemos Alberto caminhar junto a um quebra-mar, vendo navios cargueiros que passam. E então, ele decide partir, pegando um taxi rumo à rodoviária. Mais adiante, no final do filme, Alberto está sentado na praia e perde os sentidos, ao lado de Sebastião. Ouvimos, então, o mesmo som de apito de navio usado na cena do quebra mar. Há um corte e, neste momento do filme, o espectador é remetido a uma cena do começo do mesmo, a cena que marca o 
início da partida de Alberto, quando este está no muro do quebra mar. A cena transcorre da mesma maneira em termos narrativos, com pequenas alterações na decupagem. Alberto se afasta da mureta em direção ao meio-fio, acenando e entrando em um taxi. A diferença é que desta vez, a câmera não entra no taxi com Alberto. Vemos, com um movimento de grua que sobe, o taxi se afastando e se perdendo em meio aos carros. Este é o plano final do filme

Este final cíclico é que gera toda a abertura da obra, relativizando os acontecimentos sucedidos ao personagem. Trata-se de um sonho? Ou um flash de imagens de sua vida desfilando em um momento de agonia? Imaginação pura do personagem? Esta cena pode causar estranhamento no espectador no momento em que se repete, da mesma forma que o insert da imagem do doente saindo do hospital reaparece páginas a frente no romance.

As passagens descritas acima sugerem alguns dos caminhos percorridos no processo de adaptação de Hotel Atlântico de sua forma literária para outra cinematográfica. Para tentar responder a primeira pergunta que surge em relação a uma adaptação, do por quê se escolher um determinado livro como ponto de partida para se fazer um filme, talvez a resposta não esteja nas qualidades cinematográficas do romance que se prestem à adaptação, mas nas lacunas que restam de uma leitura e que o cineasta busca imaginar, completar com sua forma própria de manifestação.

"O que tem levado o cinema à literatura não é a impressão de que é possível apanhar uma certa coisa que está no livro, uma história, uma cena e inseri-la num filme, mas ao contrario, uma quase certeza de que tal operação é impossível. O que atrai não é a possibilidade, mas à impossibilidade de adaptação. A relação se dá através de um desafio como os dos cantadores do Nordeste, onde cada poeta estimula o outro a inventar-se livremente, a improvisar, a fazer exatamente o que acha que deve fazer."115

115 AVELLAR, José Carlos - Cinema e Literatura no Brasil, 1994, pg. 124 
Quando o autor se refere à impossibilidade da adaptação pensamos novamente o aforismo de Bresson ${ }^{116}$ em relação às mortes e ressurreições que o cinema sofre ao longo do processo de realização. A passagem do texto para a imagem representa a morte da abertura para diferentes interpretações que um texto tem. Criar esta abertura na leitura de como transcorre o tempo em Hotel Atlântico, representa, desta forma, "uma invenção de soluções visuais equivalentes aos recursos estilísticos do texto" 117

A frase de Manoel de Barros "No achamento do chão também foram descobertas as origens do vôo" ${ }^{118}$, que inspira este texto de Avellar nos leva a pensar nas naturezas opostas de palavra e imagem, cinema e literatura, mas também, nos sugere a complementaridade entre estes opostos. E, podemos dizer, na impossibilidade da existência de um sem o outro. "A palavra é o chão da imagem." afirmação Avellar conclui seu texto Cinema e Literatura no Brasil ${ }^{120}$, pensando, que de alguma forma, a palavra é o primeiro patamar tangível de que a imagem precisa para alçar vôo.

Quando indagamos Suzana Amaral sobre o por quê de ela ter optado por este final em Hotel Atlântico, a autora apenas se limita a dizer que veio como uma inspiração, mas que sem esta cena, ela acredita que o filme todo não teria sido possível para ela. De certa forma, a sua autoria, sua concepção do que trata esta obra se inscreve neste vôo. Neste descolamento que o filme traz em relação ao romance. Nesta abertura

${ }^{116}$ BRESSON, Robert. Notes sur le Cinématographe, Paris, Éditions Gallimard, 1988, pg. 25rd, 1988, pg. 25

117 AVELlar, José Carlos. Chão da Palavra - Cinema e Literatura no Brasil, São Paulo, Câmara Brasileira do Livro, 1994, pg. 124

118 Manoel de Barros In AVELLAR, José Carlos - Chão da Palavra, 1994, pg. 98

119 AVELLAR, José Carlos - Cinema e Literatura no Brasil, 1994, pg. 127

120 Ibid. 
que a linguagem cinematográfica possibilita melhor do que todas as outras artes, por exemplo, ao trabalhar com o tempo de forma cíclica.

\subsection{2 - A direção de atores e a decupagem em Hotel Atlântico}

Como vimos acima, no cinema de Suzana Amaral, o ator é o elemento que recebe maior atenção. Esta opção da diretora traz conseqüências para suas escolhas, que se disseminam na obra como um todo. A partir do entendimento que a direção de atores de Suzana Amaral trouxe para nós, nos indagamos; em que momento começaria, em um filme, a direção de atores? Este processo poderia começar com o casting, ou mesmo antes, no caso, na concepção que o roteirista, neste caso a própria diretora, tem de seus personagens. Mas no caso de Hotel Atlântico, ousamos dizer que algumas escolhas de Suzana Amaral nos levam a crer que a própria seleção que esta fez ao adaptar o romance para o roteiro já visava a relação que ela estabelece com seus atores e a maneira como estes devem trabalhar.

Foi mencionado que durante o processo de escrita do roteiro, Suzana Amaral raramente escreve os diálogos das cenas. Em geral, quando escreve as cenas, Suzana se limita a descrever as ações e esta forma de proceder em relação a seu texto diz mais respeito ao trabalho que deseja desenvolver com seus atores do que sua concepção propriamente dita. Estas decisões, tomadas por esta diretora, afetam o processo como um todo e da mesma maneira, podemos inferir que o diretor está de fato pensando e projetando seu filme, sob todos os aspectos a todos os momentos. Seu pensamento faz idas e vindas entre as distintas etapas, para que possa tomar as decisões que julga mais acertadas. 
Suzana Amaral não segue nenhum método de direção de atores, embora seja uma diretora bastante metódica em seus procedimentos. Sendo assim, veremos abaixo como ela trabalha, a partir de exemplos encontrados em seus filmes e também de conversas que tivemos com a diretora.

A diretora explica: "A primeira etapa é encontrar no roteiro a linha central, o tema do qual ele trata." ${ }^{121}$ Em seus outros filmes, ela conta que era possível transformar esta linha central em uma única frase que resumisse o filme, mas no caso de Hotel Atlântico, não, pois como ela afirma, a história era contada de maneira muito fragmentada e arregimentava muitos eventos. Ao nos citar este exemplo, entendemos que a diretora precisou se despir de um conhecimento acumulado em seus filmes precedentes e procurar uma nova abordagem para trabalhar neste seu projeto.

Sendo impossível resumir a linha central do filme em um eixo de ação, Suzana dividiu o filme em partes. Sobre isso, Tomas Rezende, $1^{\circ}$ Assistente de Direção em Hotel Atlântico nos conta: "Foi criado um paralelo entre a escaleta" ${ }^{122}$ do filme e trajetória do herói descrita por Campbell, em O Herói de Mil Faces. ${ }^{123}$ Desta forma, ficava mais fácil identificar a curva dramática da história de Hotel Atlântico. Muitas vezes, Suzana chamou seus atores para lembrar-lhes a que momento da trajetória do herói, uma determinada cena se referia."124 Após este procedimento, Suzana seguiu a forma como está acostumada a trabalhar, olhando individualmente para cada cena e buscando entender, tanto o sentido, como o subtexto que cada uma apresenta.

Para a diretora, aquilo que ela consegue esmiuçar desta sua análise do roteiro é o que servirá de suplemento para suas conversas futuras com seu elenco. Em seu

\footnotetext{
121 AMARAL, Suzana. Depoimento em 29/10/2015

122 Versao do roteiro contendo apenas o resumo de cada cena.

123 CAMPBELL, Joseph. O herói de Mil Faces, São Paulo, Pensamento, 2007

124 REZENDE, Tomás. Depoimento durante as filmagens de Hotel Atlântico, 2007
} 
processo, Suzana Amaral não utiliza métodos, não costuma fazer exercícios preparatórios e também não utiliza preparadores de elenco intermediando o processo da direção, pois não abre mão de estabelecer uma conexão direta com seus atores. Ela considera a presença de um preparador de elenco, uma barreira entre diretor e atores. Segundo a diretora, tudo o que ela faz é conversar muito com os membros de seu elenco.

A única intervenção externa que Suzana Amaral aceitou em Hotel Atlântico foi em função de uma necessidade que surgiu a partir do roteiro, para o personagem principal Alberto. Em decorrência da amputação que este personagem sofre, Júlio Andrade precisou de preparação física para poder executar as cenas onde Alberto apareceria já com a perna amputada. Nestas cenas, seu joelho ficaria dobrado dentro de uma cinta de lycra, feita para manter sua perna nesta posição. Na outra perna, foi usada uma prótese para torná-la mais grossa, para que as duas tivessem aparência semelhante. Durante a pré-produção, Júlio Andrade contou com a presença de um preparador físico, que elaborou uma série de exercícios para fortalecer a articulação de seu joelho e prepará-lo para suportar o esforço que a posição da perna requeria. Durante a filmagem, nos momentos em que ele precisou ficar com seu joelho dobrado, cuidados especiais foram tomados, para que o ator não sofresse nenhum dano físico: entre o final de um plano e a preparação do seguinte, colocava-se uma bolsa de gelo no joelho do ator e os exercícios foram mantidos, na medida do possível.

O início dos trabalhos de Suzana Amaral com seu elenco é sempre pautado por longas conversas. Ela prefere não abordar o texto logo no primeiro momento. Em algumas situações, inclusive, pede que o roteiro não seja entregue ao ator ou atriz, até que considere o momento certo para que este tenha contato com o texto. Por outro lado, 
o ator sabe do que se trata a história, conhece esta em detalhes e isto para a diretora é suficiente para que o elenco possa começar a elaboração de um personagem. A preocupação da diretora é de o ator poder construir bases sólidas para o personagem que irá encarnar, a partir destas conversas, antes de tomar contato com um texto, que poderia ser limitador à sua criatividade.

Para realizar a preparação de Hotel Atlântico, Suzana Amaral solicitou a presença de seus atores, durante períodos de alguns dias, em seu sítio, em Atibaia, SP. O elenco foi dividido em núcleos que passavam lá períodos curtos de 3 ou 4 dias, com o objetivo de ficarem o máximo de tempos juntos, falando sobre o filme, sem que questões externas pudessem tirar a concentração de quem quer que fosse. Os núcleos respeitavam as formações das cenas. Poucas vezes, estiveram juntos, atores que não iriam contracenar. Isto foi feito com os dois atores principais, Júlio Andrade e João Miguel e Jiddu Pinheiro e André Frateschi. Mariana Ximenes teve usa participação no filme formalizada após estes encontros, por isso não participou destas vivências. A diretora, ao propor este retiro com seu elenco, buscava desenvolver uma cumplicidade entre ela e seus atores, mas principalmente entre os próprios atores que iriam atuar juntos e, assim, edificar os personagens e a dinâmica da relação entre estes. Não foram feitos exercícios ou laboratórios enquanto estiveram lá. Ensaiaram algumas cenas e sobretudo conversaram.

Em suas conversas, ela tenta explicar aos atores seu entendimento do filme e das cenas. Estas conversas são pautadas principalmente pelo que não está dito no roteiro, apenas subentendido. E os atores colocam também seus pontos de vista para a diretora. Ela considera esta tarefa muito enriquecedora, pois é o momento de maior troca com seu elenco. Suzana afirma: "é preciso saber escutar o ator, ouvir o que ele tem para 
dizer, pois sempre surgem comentários que vão acrescentar algo à sua visão e isso vai enriquecer o filme." ${ }^{125}$ Ela alega que não acredita em um tipo de trabalho no qual o diretor não está disposto a compartilhar sua visão com o elenco e receber deste suas impressões.

Tarkovski em Esculpir o Tempo ${ }^{126}$ relata como foi preciso esconder o roteiro de Margarita Terekhova, durante as filmagens de $O$ Espelho e como a atriz ficou desapontada ao perceber que ele faria isso, mesmo tendo confiado em seu diretor o suficiente para seguir até o fim e ter atuado segundo sua intuição. Tal proposta seria algo impensável para Suzana Amaral, que busca estabelecer a cumplicidade com seu elenco. No entanto, o que Suzana Amaral possui em comum com Tarkovski a respeito da maneira como entendem a direção de atores é o fato de acreditarem que o diretor deve ser inventivo na abordagem de cada ator, pois cada um vai trazer respostas diferentes aos estímulos que forem dados. Suzana fala que ela sabe exatamente como ela quer que o ator aja, mas que é preciso que o ator faça seu trabalho por si só. Em suas palavras: "eu mostro o caminho ao ator, mas é preciso que ele percorra sozinho, acreditando que este é um desejo dele." ${ }^{127}$ Caso contrario, o risco é criar uma atuação mecânica, por alguém que apenas busca fazer o que esperam dele.

Pode parecer contraditório com a afirmação acima, mas Suzana diz que coloca acima de tudo a liberdade do ator ao criar, que a criatividade do ator é o fator que mais leva em conta, enquanto trabalha com seu elenco. No entanto, ao observarmos como este trabalho ocorre na prática, percebemos que não se tratam de afirmações contraditórias, mas complementares. Ela tem objetivos em mente que se completam ao

\footnotetext{
125 AMARAL, Suzana. Depoimento em 29/10/2015

126 TARKOVSKI, Andrei. Esculpir o Tempo, São Paulo, Martins Fontes, 1998, pg. 173

127 AMARAL, Suzana. Depoimento em 29/10/2015
} 
receber a visão do ator. O que surge é fruto de um trabalho comum, com influências mutuas.

Se em suas conversas com o elenco Suzana tenta passar a sua visão do filme, quando os atores se colocam em cena ela apenas observa como o ator vai resolver os problemas colocados em cada uma das cenas. Isto inclui a criação dos diálogos, a movimentação e a interação com os demais que estão na cena. Neste momento, a diretora se coloca na postura de observadora. Este é o seu momento de maior observação e escuta. Em um primeiro momento, ela não interfere.

Os atores passam a cena até o fim, sem nenhuma diretriz que não seja a conversa prévia desenvolvida. Quando algo está bom, ela deixa fluir, deixa que o ator explore aquele caminho. Por outro lado, se ela sente que algo se desvia do que ela pretende, chama, individualmente o ator e conversa calmamente, em um tom que não possa ser escutado por todos. Suzana busca especialmente manter a privacidade destas conversas de redirecionamento e não expor o ator em seu momento de criação. Ela faz uma comparação: “atores são como peças delicadas, se em um deslize manejamos de forma desajeitada, aquilo pode deixar uma marca por todo o trabalho." ${ }^{128}$

É durante as filmagens, no entanto, que pode se verificar o rigor do trabalho entre elenco e direção. Suzana Amaral inicia cada dia de filmagem trabalhando apenas com o elenco, acompanhada de um de seus assistentes de direção. Em geral, ela convoca o elenco da cena pela qual vai começar a trabalhar, uma hora antes do início dos trabalhos da equipe técnica. Os atores chegam sabendo por qual cena deverão começar o ensaio, que é realizado já no cenário definitivo e com os objetos que serão empregados na filmagem. A diretora acredita ser insubstituível trabalhar no espaço

128 AMARAL, Suzana. Depoimento em 29/10/2015 
definitivo, com os objetos que deverão figurar no filme. Para os atores, acrescenta muito em sua ambientação e para a diretora, é fundamental na pré visualização do que será filmado.

Suzana Amaral procede desta maneira, para que sejam os atores os primeiros a encontrar a forma de se mover no cenário, criando o sentido da cena. Os atores, têm por exemplo, liberdade de criar marcações que não estavam previstas, ou mesmo se valer de objetos presentes no set de filmagem, que não estivessem citados nas cenas. Conforme há o amadurecimento da cena e ela percebe que as possibilidades se esgotaram, ou atingiram aquilo que a diretora tinha em mente, Suzana Amaral reúne seu elenco e os consulta se estão satisfeitos com o que foi elaborado, ou se ainda possuem alguma dúvida em relação a qualquer aspecto. Se todos estão de acordo, a cena é considerada pronta para ser rodada, ou nas palavras de diretora: "tranca-se a cena." ${ }^{129}$ Uma vez construída a cena, a marcação tende a se condensar e ser seguida como uma partitura.

Suzana também não prepara a decupagem de antemão, pois sabe que ao propor esta forma de trabalho para seus atores, terá de se adaptar ao que for edificado por estes. A partir do que os atores elaboram em termos de movimentação, ela saberá onde a câmera deve se posicionar. Quando a equipe técnica chega ao set de filmagem, suas instruções são precisas quanto aos posicionamentos de câmera.

Os momento em que Suzana cria a decupagem antes de proceder os ensaios são nas cenas de ação, nas quais existe um grande aparato de equipamentos ou a necessidade de se articular elementos técnicos, sem os quais a cena não será funcional. Para estas cenas, seu procedimento é instruir os atores quanto às suas movimentações, mas mesmo assim, estes ainda têm total liberdade de propor diálogos e o tom da

129 AMARAL, Suzana. Depoimento durante as filmagens de Hotel Atlântico, 2007 
atuação. Em uma cena rodada com Júlio Andrade, André Frateschi e Jiddu Pinheiro, Frateschi se valeu de uma informação do romance, no qual seu personagem e o de Pinheiro eram descendentes da colônia alemã do sul do país. Seu personagem, em momentos de nervosismo e fúria, soltava interjeições em alemão.

Pode-se dizer que a forma de enquadrar e dividir a cena de Suzana Amaral obedece à noção clássica da mise-en-scène, na qual há a preeminência dos atores e a organização da cena a partir dos corpos posicionados no espaço; o conceito de mise-enscène lapidado por Michel Mourlet se aplica à forma como Suzana Amaral conduz suas filmagens: “A colocação dos atores e dos objetos, seus deslocamentos no interior do quadro devem tudo exprimir." ${ }^{\prime 130}$ Os atores são os elementos centrais de seu cinema, portanto parece lógico que sejam os primeiros a encontrar seus lugares, em ação. A câmera vai segui-los. Após a cena "trancada" Suzana Amaral permite que o restante da equipe entre e neste momento, ela apresenta a cena à equipe técnica, para que estes possam afinar a arte, iluminar o cenário, entre outras tarefas. O próximo passo é discutir de que maneira concebeu os enquadramentos, quantos planos pretende rodar e o que mais for pertinente no momento da filmagem.

Se por um lado, este método, valoriza o trabalho do ator e sua liberdade em cena por outro pode, em determinados momentos, resultar em situações de atrito com a equipe. Um dos exemplos foi uma ação criada em Hotel Atlântico por Gero Camilo para o personagem Sacristão Antônio. Em uma cena, ele conversava com Alberto, os dois sentados à mesa.

\section{“45. INT. CASA DO SACRISTÃO/ COZINHA /QUARTO - DIA}

ALBERTO, vestido de batina, toma café - come uma grossa fatia de pão - e está vestido com a batina do padre Anselmo. ANTONIO está sentado na mesma cadeira

${ }^{130}$ MOURLET, Michel. Sur Un Art Ignoré, Cahiers du Cinema, Paris, 1959, pg. 27 
em que havia estado sentado quando ele chegou.Tem um terço em suas mãos. Só que agora a cadeira está virada para ele. MARISA , meio cúmplice com ALBERTO, escuta e eles se olham."131

A equipe estava preparada para que a cena seguisse o que estava descrito no roteiro, no qual o sacristão comia uma grossa fatia de pão. No entanto, durante os ensaios precedentes, Gero Camilo e Júlio Andrade criaram um desenho para a cena, na qual o Sacristão Antônio cortava um pedaço de pão para Alberto. Depois cortava um pedaço para si e após acabar esta primeira fatia, cutucava o pão com os dedos, fazendo pequenos buracos no miolo. Inicialmente, o pão inteiro estava previsto no cenário apenas como um objeto decorativo. Foi pedido pela direção que se conseguissem outros pães para a cena, possibilitando assim, que várias tomadas fossem rodadas. Sabe-se que imprevistos em filmagens podem gerar atrasos, motivo de tensão para toda a equipe. Apesar de não se tratar de um pedido impossível de ser realizado, a locação se encontrava a alguns quilômetros da cidade, onde havia a padaria mais próxima. Foi preciso que se esperasse pelos pães adicionais para que e a cena pudesse ser rodada, conforme definida pelos atores, tendo sido editada no filme.

Os diálogos também são propostos pelos atores. Pode ocorrer de alguma fala ser indicada previamente, mas apenas quando se trata de algo determinante para que o filme se torne compreensível ao público. Quando os ensaios de determinada cena são realizados antes das filmagens, ela pode chegar a acrescentar alguma indicação sobre o que foi dito na criação da cena, ao roteiro. No entanto, é comum chegar ao momento da filmagem com a cena escrita contendo apenas as indicações de linhas gerais das ações.

131 AMARAL, Suzana. Hotel Atlântico, São Paulo - Roteiro Cinematográfico, 2007 
A exemplo de como os diálogos são sugeridos pelos próprios atores, em uma passagem do filme, há uma cena entre Alberto (Júlio Andrade) e Diana (Mariana Ximenes), na qual Diana tenta seduzir Alberto no interior da capela do hospital, culminando com o fracasso de Alberto, que se encontra em convalescença após a amputação de sua perna. No roteiro, a cena aparece da seguinte forma:

\section{“64 A. INT. HOSPITAL/ CAPELA - DIA}

A pequena lamparina na capela ilumina o altar e informa que o santíssimo está ali presente. Eles entram no recinto santo. Ela fecha a porta com chave depois que entram. Empurra a cadeira até a altura do último banco da capela. Ela senta no banco, inclina-se e o abraça.

DIANA tira pra fora o seio e o oferece.

Os dois passam para o banco da capela. ALBERTO a acaricia e a beija... Ela fica estimulada... Retribui. ALBERTO apalpa a braguilha de sua calça. Percebe uma ereção incompleta... Desiste..." ${ }^{132}$

Uma das diretrizes que Suzana Amaral passou para Mariana Ximenes foi a de que ela lesse também o livro do qual o roteiro foi adaptado, pois acreditava que o livro poderia trazer alguma informação sobre a personagem Diana, que não estivesse presente no roteiro. Suzana também procedeu como com os demais atores, ao conversar e expressar seu ponto de vista sobre a personagem e as cenas que seriam desempenhadas por ela. No entanto, como costumeiro, não passou nenhuma orientação sobre como gostaria que a cena fosse executada entre os dois atores.

No livro esta passagem aparece da seguinte maneira:

"E abriu a porta da capela. Depois me levou até passar a porta e girou a chave.

Aí empurrou a minha cadeira de rodas até a altura do último banco da capela. Inclinou-se, e me abraçou.

Pedi que ela abrisse os botões do vestido. Eu peguei um seio. Era tão pequeno que quase cabia inteiro na minha boca.

132 AMARAL, Suzana. Hotel Atlântico, São Paulo - Roteiro Cinematográfico, 2007 
Ela tirou para fora o outro seio, falou que viesse naquele também. Esse seio tinha o gosto mais adocicado.

Botei a mão na braguilha do pijama, percebi que eu apresentava uma ereção ainda incompleta." 133

Havia uma dificuldade na movimentação, pois Júlio Andrade estaria usando a prótese de lycra para uma perna e a outra estaria dobrada e presa, simulando a amputação. Além disso, os atores teriam de coreografar os movimentos da passagem da cadeira de rodas para o banco da capela. Vale ressaltar que Mariana Ximenes teve grande liberdade para opinar sobre o figurino, chegando a trazer peças de roupas suas para o filme. O vestido que utiliza nesta cena, era uma destas peças que emprestou para a composição da personagem Diana. O vestido, adequado para aquele momento da personagem oferecia praticidade na movimentação, motivo pelo qual foi eleito para a cena.

A exemplo de adaptações feitas pelos atores, diretamente do livro para o filme, Mariana Ximenes propôs, para esta cena, recuperar algumas informações que estavam no texto do romance. Diana se sentaria no colo de Alberto, onde tiraria o seio para fora do vestido e depois oferecia o segundo seio. Ao fazer isto, ela falava o seguinte diálogo: "Pegue este, que é mais doce."134 Após a filmagem desta cena, diretora estava exultante com o diálogo, que trazia à tona o lado malicioso da personagem, apresentada ao espectador em um primeiro momento, como uma moça ingênua, apreciadora de telenovelas. A montagem, ainda, se constitui como o recurso final de intervenção do diretor sobre o trabalho do ator sendo esta uma etapa sobre a qual o ator normalmente não tem controle. Na montagem, todos os diálogos desta cena foram suprimidos, mas se fizeram necessários para que se chegasse ao tom desejado da cena ao ser filmada. Para

133 NOLL, João Gilberto. Hotel Atlântico, São Paulo, Francis, 2004, pg. 80

134 Diálogo proferido pela personagem Diana, interpretada por Mariana Ximenes, durante as filmagens de Hotel Atlântico, 2007 
se alcançar o resultado que se vê na tela, este caminho descrito precisou ter sido percorrido pela diretora e seus atores.

Durante o processo de filmagens de Hotel Atlântico, o elenco principal mostrava-se positivo em relação ao trabalho realizado, havia uma conexão estabelecida com sua diretora, em quem eles aparentavam depositar confiança. Em outras palavras, a atitude dos atores demonstrava que Suzana Amaral havia conseguido estabelecer a cumplicidade que almejava para, junto com seu elenco, concretizar a filmagem.

\subsection{3 - Direção e montagem}

Ao escrever o roteiro, Suzana Amaral imagina que o mesmo a acompanhará, durante as etapas do processo que se estendem da pré-produção à montagem. Como referido, a diretora confere grande importância ao texto e às decisões que foram cristalizadas neste momento da realização. Durante as filmagens é bastante criteriosa em relação a qualquer modificação que possa vir a ser feita ao roteiro inicial, pois acredita que o momento da filmagem possui demandas que podem dificultar as tomadas de decisão por parte do realizador. Ao escrever o roteiro, a diretora está em geral sozinha, ou dividindo a tarefa com mais uma pessoa. Em contrapartida, no momento da filmagem, são diversos os colaboradores presentes, deve-se dar atenção ao elenco e o cronograma precisa ser respeitado para que se possa concluir as filmagens com êxito. Suzana descreve este momento como se uma locomotiva de trem estivesse ao seu encalço e que ela deve sempre se antecipar para não ser atropelada pelos problemas que podem vir a surgir. Por esta razão, ela evita operar mudanças ao roteiro no momento do set. Em situações extremas, consegue reservar um momento no final do dia, após o término da diária. 
Um dos raros exemplos presenciados de alterações feitas ao roteiro, no entretanto, não resultou em mudança de sentido para a cena, já que esta foi transposta para uma locação diferente. A cena se desenrolava inicialmente em um cenário que havia sido todo construído para o filme e devia representar a entrada de um prostíbulo, cenografado em um casa de fazenda, que encontrava-se desabitada. Os atores propuseram uma movimentação na hora do ensaio que deslocava a ação que deveria acontecer neste cenário para o que viria posteriormente. Aquele local servira apenas como uma passagem. Por conta deste atalho encontrado pelos atores para o desenrolar da cena e constatando que não se acrescentava nenhuma informação ao andamento da narrativa, Suzana Amaral decidiu-se por inutilizar todo o cenário, cancelando a filmagem ali prevista, pois para esta diretora, a economia de meios é um lema a ser seguido. Finalmente, na montagem, Suzana acabou descartando toda a cena da entrada no prostíbulo, incluindo os planos em que Alberto, Nelson e Léo eram recebidos pelas prostitutas. A sequiência contou apenas com a segunda parte, na qual Alberto conhece a prostituta com quem irá passar a noite.

Mesmo sabendo que o roteiro deverá servir como um guia e que este pode ser acessado pela montadora, Suzana Amaral não abre mão de acompanhar todos os momentos da montagem. Ela entende que o montador, como qualquer outro colaborador da equipe, pode trazer sugestões preciosas, mas que só o diretor, que acompanhou as filmagens, possui um conhecimento íntimo do material, necessário para que o filme se concretize nestas etapas finais.

A diretora afirma que a concepção da montagem tem início no próprio set de filmagens, ao observar o resultado dos planos filmados. Mesmo que este embrião da montagem se modifique bastante, ao se trabalhar sobre o material, esta afirmação de 
Suzana Amaral, reflete alguns dos princípios que enumeramos sobre o processo criativo do cinema, de que as decisões vão se condicionando sucessivamente e como conseqüência, as etapas da realização são engendradas em suas precedentes.

A diretora segue um lema que sempre repete em aulas para seus alunos: "menos é mais" 135 e ainda cria uma comparação: "quando se tenta colocar muita coisa dentro de um pacote, o pacote não fecha. Mas se você coloca somente o necessário, consegue fechá-lo da forma como deve ser feito." ${ }^{136}$ Comparando estas duas declarações, dadas em um espaço de 15 anos pela diretora, vemos que ela se mantém fiel aos princípios que edifica para si, em relação ao cinema. Se suas decisões são regidas pelas escolhas tomadas ao longo de sua vida como diretora, suas realizações são a confirmação da metodologia de trabalho colocadas em prática. Esta forma dialética encontrada entre teoria e execução nos remete à compilação de Jacques Aumont ${ }^{137}$, quando este afirma que as teorias dos cineastas possuem como característica o fato de terem sido forjadas em relação ao fazer e os problemas concretos que surgem em seus ofícios de realizadores

Suzana Amaral não teme descartar cenas, ou mesmo seqüências de cenas inteiras em que um ator aparece. Em Hotel Atlântico, várias cenas acabaram cortadas e com elas algumas participações, como foi o caso da atriz Paula Braun.

Paula Braun, no momento das filmagens de Hotel Atlântico havia alcançado uma certa visibilidade com sua participação em $O$ Cheiro do Ralo ${ }^{138}$ (2006) de Heitor Dhalia. A atriz aceitou modificar seu visual, cortando e tingindo os cabelos para interpretar a recepcionista do hotel descrita da seguinte forma: "A moça tinha os

\footnotetext{
135 AMARAL, Suzana. Depoimento durante aulas de Direção Cinematográfica na ECA- USP, 2000 136 AMARAL, Suzana. Depoimento em 29/10/2015

137 AUMONT, Jacques. A Teoria dos Cineastas, Papirus, Campinas, 2004

138 DHALIA, Heitor. O Cheiro do Ralo, São Paulo, 2006
} 
cabelos pretos, uma franja espessa, os cabelos vinham até logo abaixo das orelhas. Parecia uma melindrosa." 139 A personagem possui algum destaque no romance e da mesma maneira, tinha sido mantida no roteiro. Na montagem, porém, a diretora notou que este bloco de cenas era muito longo para estar tão próximo ao início do filme, fator que ralentava a partida para a viagem sem volta que Alberto iria empreender e que de fato é o tema principal deste filme.

Um plano, ao ser filmado, possui um tempo interno das ações, que não pode ser modificado posteriormente, salvo utilização de efeitos de aceleração ou ralentar da imagem. No entanto o corte é uma forma de alterar o ritmo geral de um filme, ao se determinar qual será o tamanho do plano, dentro da estrutura maior que é o filme. O diretor consolida os tempos de seu filme, uma primeira vez na filmagem e, posteriormente, na montagem, ao estabelecer com que freqüência haverá alternância de planos em uma cena e no filme todo.

Existe a questão do ritmo que determina a montagem, mas a diretora também alega que muitas cenas são cortadas pois a informação que ela contém foi expressa por outra cena. Ou como ela traduz: "às vezes a imagem de uma outra cena contígua se mostra muito forte, ou a imagem mostra coisas demais e o filme não precisa dizer tudo."140

Esta reflexão de Suzana Amaral sobre o que é cortado na montagem diz respeito às diferentes formas que o filme assume ao longo de sua feitura. $\mathrm{O}$ roteiro poderia dar a falsa impressão de que o filme assumiria aquela proposta inicial de sequiência das cenas, pois ao se terminar um roteiro, o diretor o considera como um guia de sua fase

139 NOLL, João Gilberto. Hotel Atlântico, São Paulo, Francis, 2004, pg. 12

140 AMARAL, Suzana. Depoimento em 29/10/2015 
posterior do trabalho. Em geral se diz dos roteiros acabados que estão prontos para ser filmados. E sendo assim, durante a filmagem e principalmente, depois, na hora da montagem, percebe-se que existem sobras, ou que uma cena pode funcionar melhor se deslocada para outra parte do filme. Estas mudanças reiteram que as metamorfoses que um filme sofre ao longo de sua feitura envolvem mais do que a simples transposição das palavras para imagens e sons. A cada etapa, deve-se encontrar uma nova forma, para que se mantenha a coerência interna da obra.

Como descrevemos anteriormente, podem existir problemas relacionados à própria realização da cena, de não ter se atingido o que se almejava. Mas também pode se suceder de a cena ser considerada bem filmada por seu diretor e mesmo assim se tornar excessiva quando justaposta às outras.

O filme In the Mood For Love $e^{141}$ (2000) do diretor Wong Kar Wai havia sido concebido como um filme de romance entre dois vizinhos, com diversas cenas onde o romance entre os dois era consumado ${ }^{142}$ e no entanto no momento da montagem, o diretor resolveu transformá-lo em um filme sobre a incerteza, onde nada é mostrado de maneira explícita. Para o espectador, as perguntas ficam sem respostas definitivas, podendo gerar interpretações variadas. As imagens entre os dois protagonistas tornariam incontestável o envolvimento destes e condicionariam o sentido do filme, enquanto o que é sugerido de maneira parcial cria um novo subtexto para o filme. Este deixa de ser um filme de amor e se torna um filme sobre uma mulher que tem medo de se entregar a uma relação por pudor. $\mathrm{O}$ interesse pelo filme pode surgir à medida que $\mathrm{o}$ espectador precisa preencher as lacunas deixadas por seu diretor.

${ }^{141}$ KAR WAI, Wong. In The Mood For Love, 2000

142 Site IMDB.com: http://www.imdb.com/title/tto118694/trivia?ref_=tt_trv_trv - consultado em 10/10/2015 
Ao pensarmos no processo de realização Hotel Atlântico, as cenas de Paula Braun, cortadas do início do filme levaram mais de três diárias para serem filmadas, houve um investimento de tempo, trabalho e parte do orçamento significativos para que estas atingissem seu potencial. O fato de não figurarem na montagem é representativo das escolhas feitas pela montadora e pela diretora. Faz parte da natureza da montagem organizar o que foi filmado, mas também saber separar aquilo que em algum momento deste processo, deixou de ser o filme. E é preferível sacrificar algumas cenas para que o filme continue uma obra coesa.

\subsection{4 - Opções quanto à trilha sonora do filme}

Muitos dos sons descritos no romance, estão presentes no filme. Acima, mencionamos que Suzana Amaral opta por manter a linguagem cinematográfica como um alicerce para contar a história, mas que esta não se sobrepõem à narrativa. A linguagem cinematográfica, no caso, é transparente, o espectador segue o personagem em suas peripécias como um observador. Por este motivo, o som não procura reproduzir um ponto de escuta particular, mas tenta ser condizente com a imagem, buscando criar a verossimilhança deste universo recriado, seguindo um padrão adotado pela maioria das narrativas clássicas do cinema.

No entanto, ao analisarmos criteriosamente, podemos notar que não se trata de utilizar sons que foram captados unicamente, da forma como se apresentaram no momento da filmagem, ou seja, não se trata apenas de som direto. Há a utilização de uma trilha sonora que foi recriada em muitos momentos e que alguns elementos chegam a ser irreais, como por exemplo uma freada de pneus em uma estrada de terra antecipando uma batida de carro. O espectador tende a não sentir estranheza diante 
deste detalhe que passa tão rápido, mas este é apenas um exemplo de como o som que busca construir esta verossimilhança não necessariamente se apóia em elementos da realidade. Podemos notar que o uso do som é pouco explorado do ponto de vista sensorial, mas por outro lado estabelece-se como um recurso narrativo.

Outra característica que podemos notar neste filme é a construção da trilha sonora de forma a destacar a presença dos personagens, em especial do personagem principal, presente em todas as cenas do filme. Há uma tendência a evidenciar os movimentos e ações dos personagens, através de ruídos de passos, farfalhar de roupas, ruídos causados pela manipulação de objetes, chamando a atenção do espectador para suas ações. Em alguns momentos esta escolha é acentuada, pelo destaque dado ao som de respiração dos personagens, em especial do protagonista.

Selecionamos algumas das indicações, de elementos sonoros citados no livro, consideradas mais relevantes e fizemos uma análise da trilha sonora do trecho correspondente no filme. Quando necessário, utilizamos também o roteiro como um dado de comparação, no intuito de verificar se os elementos sonoros estavam presentes já nesta etapa de desenvolvimento do filme. Não foram transcritos os diálogos dos trechos correspondentes que aparecem no livro.

\section{Bloco 1:}

\section{"8. EXT. AVENIDA À BEIRA MAR - DIA}

ALBERTO caminha ao lado de um parapeito à beira-mar. Ao descer o meio fio, mete os pés num charco escuro da sarjeta.

(Vemos seu reflexo na água da sarjeta).

POV de Alberto NA ÁGUA SUJA E NA BARRA DA CALÇA. 
Cria coragem e sinaliza a um táxi: o carro pára. Ele entra. O carro segue."143

Nesta cena, vemos Alberto que sai do hotel e caminha pelas mesmas ruas por onde andava na cena inicial. Mas desta vez escutamos o ambiente urbano, embora pouco presente ao fundo, mas com elementos que se destacam e ganham primeiro plano, como a passagem de um caminhão.

A passagem deste caminhão funde-se com o som de um apito de navio, antecipando a imagem seguinte. Não é um som que identificamos como um som diegético imediatamente. Ele ainda possui um timbre muito parecido com timbres presentes na música inicial.

Com esta passagem sonora, há uma elipse e o personagem se encontra em um quebra mar. Aqui nesta cena há um contraste do pulso dado pelo apito lento do navio e da água batendo no quebra mar com a velocidade e intensidade dos carros que passam na avenida ao lado. A cena se inicia mais lenta com a passagem do navio e se acelera, com o caminhar do personagem na direção da avenida, com um crescendo do som dos carros. A água, destacada do demais sons, batendo no concreto, está mais presente na primeira parte da cena.

Este bloco não faz parte do livro. Foi criado no roteiro como uma sequiência de passagem, e que volta no final, criando a circularidade da história. O apito do navio talvez seja o elemento sonoro mais importante de todo o filme. Ele pode ser lido como a decisão de Alberto em viajar, sobre a qual ele fala ao longo de todo o romance. Esta leitura é atribuída ao fato de este som ser reiterado quando, no final, voltamos à mesma sequiência. Este som pode ter sido a base para a criação da música de abertura, que

143 AMARAL, Suzana. Hotel Atlântico, São Paulo - Roteiro Cinematográfico, 2007 
possui timbres e notas que fazem referência ao mesmo. Este som, no entanto, não está presente no roteiro.

\section{Bloco 2:}

"O motorista falava, mas eu não consegui entender. Num momento entendi que ele falava do frio das estepes russas. Ele disse que as estepes russas eram tão frias como a morte. Isso eu ouvi com toda a clareza. Eu voltava a entender. O trânsito. O motorista comentando a poluição do túnel Rebouças"144

Dentro do taxi temos o diálogo que se destaca de todo o resto. E o motor do próprio carro, bastante barulhento, mas que não interfere na conversa. Inclusive, o início do dialogo é filmado com a câmera do lado de fora do pára-brisa e ouvimos perfeitamente o que diz o protagonista, deixando clara a opção colocar os atores sempre em primeiro plano.

Não existe na edição de som nada que faça alusão à confusão mental de Alberto, referida na livro, ao dizer que não consegue entender o que o motorista está falando. A diretora optou por fazer com que o personagem pergunte a seu interlocutor, como se não tivesse ouvido o que ele falou.

A seguir destacamos as citações sonoras que aparecem ao longo de 16 páginas do romance e que resultam no bloco de cenas nas quais Alberto tenta fugir de Nelson $e$ Léo.

\section{Bloco 3}

“Nelson ligou o rádio.".145

144 NOLL, João Gilberto. Hotel Atlântico, São Paulo, Francis, 2004, pg. 20

145 NOLL, João Gilberto. Hotel Atlântico, São Paulo, Francis, 2004, pg. 42 
"Cachorros latiam nas imediações, e Nelson então recostou-se no banco do carro $(\ldots))^{\prime 146}$

“Três cães policiais presos numa estaca de ferro à entrada da construção de madeira latiam desbragadamente."147

"Nas bordas do mato parei. Ouvi vozes." 148

“As vozes, que tinham silenciado, voltaram. Dessa vez mais próximas. Não custei muito então para perceber que eram as vozes de Nelson e Leo, Nelson agora não falava muito alto mas discutia claramente com Leo."149

“... e aí, vieram os tiros por trás, era Nelson vindo ao meu encalço.”150

“...ouço tiros, Nelson vem atrás disparando tiros certamente para atingir os pneus..."151

“... ouço os tiros cada vez mais longe, o latido dos cães já num sumidouro, uns dez minutos depois silêncio absoluto, paro o carro."152

"Eu estava sozinho, olhando a paisagem que parecia um planalto, quando ouvi a voz do rapaz da carroça atrás de mim." ${ }^{153}$

Uma das cenas correspondente ao bloco descrito:

\section{“38. EXT. FAZENDA OÁSIS - DIA}

ALBERTO anda pelos caminhos da mata: caminho com pedras, raízes, escorregadio. Logo depois o rio claro, belo, aprazível. Ele vai pela margem do rio num atalho arenoso. Às vezes joga uma pedra no rio...

ALBERTO anda pelos atalhos...

Logo depois vê sangue no chão...

O sangue continua à direita fazendo uma trilha que entra pelo mato. Caminha acompanhando o sangue.

\footnotetext{
146 NOLL, João Gilberto. Hotel Atlântico, São Paulo, Francis, 2004, pg. 42

147 Ibid., .pg. 51

148 Ibid., pg 52

149 Ibid., pg.52

150 Ibid., 54

${ }^{151}$ Ibid., 54

152 Ibid., pg. 54

153 Ibid., pg. 58
} 
Na borda do mato ele pára. Ouve vozes.

Num impulso, pára e pega uma pedra. As vozes silenciam mas voltam mais próximas. Distingue as vozes de NELSON e LEO. ALBERTO esconde-se atrás de uma árvore.

Pela fenda vê LEO e NELSON num lugar lamacento e escondido..." ${ }^{154}$

Estas 16 páginas do romance são a maior concentração de indicações de elementos ouvidos pelo personagem principal. A maior parte destas indicações não existe no roteiro, que no entanto, de modo geral segue a narrativa proposta pelo romance. Há uma seqüência criada pela diretora, em que os personagens trocam um pneu de uma caminhonete, editada no filme, mas a maior parte das cenas roteirizadas foram cortadas na montagem. As indicações de sons do livro que sobreviveram no roteiro foram que Nelson liga o rádio da caminhonete e os cachorros que ladram ao longe.

A presença dos cachorros é muito importante para a narrativa, pois mais uma vez, temos um clima ameaçador e os latidos de cachorro são o elemento da trilha sonora que contribuem para traduzir esta tensão ao espectador. A cena com os cachorros foi filmada e havia inclusive uma questão quanto aos cachorros, que não pareciam tão ameaçadores quanto a diretora gostaria que fossem. A diretora esperava que com os latidos, acrescidos na edição de com a presença dos animais ganhasse peso no filme.

Nestas cenas, temos um início de viagem tranqüilo, com uma pausa para a troca de pneu em que a opção da edição de som é trabalhar com poucos elementos: ouvimos sons de elementos que estão na imagem, proveniente da movimentação dos atores, o motor da caminhonete quando em movimento, o pneu furando, ruídos de sala e na pausa um ambiente de um campo bastante calmo, com a presença sonora de poucos animais silvestres. Ouve-se grilos, uma cigarra, e ocasionalmente um pássaro que canta na parte

154 AMARAL, Suzana. Hotel Atlântico, São Paulo - Roteiro Cinematográfico, 2007 
final de um plano, mas que parece vir do próprio som direto. Não são acrescentados outros elementos para povoar este campo.

Na cena seguinte em que vão surgir os elementos de ameaça, já escuta-se um motor de caminhonete mixado mais alto, ele é mais presente e mais agressivo no timbre do que na cena anterior. E então entram os latidos de cachorro. O personagem caminha e se aproxima de um rio. O som do rio aparece junto com a imagem, ele não é perceptível nos arredores. Mais uma vez ouvimos o som da água em destaque, como ao longo de todo o filme. Mas aqui a queda d'água é ameaçadora. Trata-se de um som que encobre todos os outros.

Este bloco do filme reafirma uma escolha da diretora em trabalhar com elementos naturalistas, sem trazer nenhum tipo de comentário à imagem, que não sejam elementos pertencentes a uma realidade provável. Não existe música ou qualquer outro efeito que não pertença à realidade estabelecida pela cena. E é com estes elementos presentes que se cria a tensão. Os cachorros, a água do riacho e da cachoeira, mixada de forma a esmagar todos os outros sons ao redor.

Neste trecho temos uma proximidade muito grande entre o livro, o roteiro transcrito e a forma do filme. A forma como o autor descreve no romance a aproximação, a visualização do sangue, as vozes que surgem, o reconhecimento por Alberto das vozes como sendo dos personagens Nelson e Leo correspondem a maneira como estas informações vão sendo reveladas no filme. Pode-se dizer que há uma equivalência no tempo da escrita e no tempo fílmico, entre o estilo da escrita e a montagem.

No romance, primeiramente ouve-se vozes, depois admite-se a possibilidade de que sejam de Nelson e Leo, antes de se reconhecer plenamente como sendo de fato 
destes personagens. Então entendemos o discurso, e por fim vemos a imagem de Nelson com um revolver na mão, dizendo a Léo que ele deve matar o artista, forma como este se refere a Alberto.

Esta fala provoca a fuga de Alberto pelo meio do mato. Há um crescendo dos sons, que contribuem para que a tensão do espectador também aumente. Os cachorros já estão bem menos presentes neste momento. Ouvimos no som ambiente o rio ao fundo e outros animais silvestres, como pássaros e insetos, ao longe um mugido. Então os sons dão espaço para a introdução das vozes que depois viram o diálogo. A fuga de Alberto se inicia com passos e ruídos provocados pela movimentação de Alberto e Nelson no mato. Então, a respiração ofegante de Alberto ganha espaço, que é também um elemento gerador de tensão e que aproxima o espectador do personagem. O ambiente se mantém, mas vai sendo encoberto pelos outros sons. Então Alberto se aproxima dos cachorros que estavam mais silenciosos e neste momento vêm os tiros e o motor da caminhonete em fuga. A caminhonete se afasta, mas ainda ouvimos mais tiros, os cachorros e os gritos de Nelson.

\section{Bloco 4}

"E começou a cantar uma música que eu nunca tinha ouvido."155

“...foi assim que eu fui caindo, e enquanto eu desmoronava a primeira coisa que senti foi que eu ia perdendo a audição - e quando o meu corpo inteiro se espatifou na laje do banheiro eu já estava completamente surdo. Eu via muito bem, via perfeitamente a expressão de Sebastião debruçada sobre mim, mexendo com a boca, me falando coisas que eu não conseguia mais ouvir." ${ }^{156}$

"Eu sabia que Sebastião caminhava, eu sabia de tudo, normalmente, mas já não possuía a audição.

155 NOLL, João Gilberto. Hotel Atlântico, São Paulo, Francis, 2004, pg. 104

156 Ibid., 105 
O mundo tinha ficado mudo, era só silêncio.".157

"Pelo movimento dos seus lábios eu só conseguia entender a palavra mar."158

\section{“ 81. INT. HA FINAL/ QUARTO - DIA}

\section{$(\ldots)$}

Do banheiro, SEBASTIÃO recomeça a cantar a música interrompida.

ALBERTO levanta-se e num pé só chega até a porta do banheiro. Olha SEBASTIÃO e vê que ele faz a barba.

SEBASTIÃO vê ALBERTO pelo espelho (ele está sem as muletas).

POV MÚtUO: SEBASTião vê ALBERTo pelo espelho - ALBERTO vê SEBASTIÃO pelo espelho. Os dois se encaram.

\section{SEBASTIAO}

E aí companheiro? ...O dia está especial pra conhecer o mar... Já viu lá fora, que lindo dia?

\section{ALBERTO}

Sebastião...

SEBASTIÃO enxuga o rosto com uma toalha.

\section{ALBERTO}

O primeiro dia do mundo...

ALBERTO diz isso e subitamente sente uma fraqueza infinita, escorrega pelo umbral da porta. Vai caindo como se estivesse desmaiando...

Sente que começa a perder a audição... Quando seu corpo chega no chão, está completamente surdo.

SILÊNCIO ABSOLUTO. Nenhum som se ouve. Mas ele enxerga tudo.

POV DE ALBERTO: O rosto de SEBASTIAO se aproxima dele e seus lábios se movem.

\section{SEBASTIAO}

$$
\text { Vamos ver o mar? }
$$

ALBERTO não consegue ouvir, mas vê os movimentos dos lábios de Sebastião...

ALBERTO tenta falar mas não consegue. Repete o movimento dos lábios - fala mudo...

157 NOLL, João Gilberto. Hotel Atlântico, São Paulo, Francis, 2004, pg.106

158 Ibid., 106 
SEBASTIÃO pega ALBERTO nos braços: um braço nas costas, outro na perna.

ALBERTO sente as veias da fronte, do pescoço e dos pulsos que disparam.

SEBASTIÃO SAI COM ALBERTO NO COLO PARA O PÁTIO.

\section{EXT. HA FINAL/ PÁTIO - DIA}

Quando SEBASTIÃO sai do quarto, os olhos de ALBERTO não agüentam a claridade e se fecham.

SEBASTIÃO carrega ALBERTO nos braços em direção ao mar.

Depois do choque da claridade, ALBERTO reabre os olhos e vê o mundo de cabeça para baixo...

POV DE ALBERTO VENDO TUDO DE CABEÇA PARA BAIXO.

O MUNDO FICA MUDO: Silêncio total.

POV DE ALBERTO:(invertido tudo que pode existir no pátio):

- UM CACHORRO CORRE

- GALINHAS CISCAM

- UMA CRIANÇA CORRE..."159

Nas cenas finais volta-se ao registro naturalista na edição de som. As indicações que estão no roteiro seguem o que é descrito no livro; isto é, a perda total dos sentidos de Alberto é descrita como tendo início com a perda do sentido da audição. Esta era uma opção inicial, que foi mantida mesmo durante as filmagens. O ator João Miguel articulava exageradamente a boca, pois embora suas falas tenham sido captadas pelo som direto, a proposta inicial era de se editar seus diálogos sem som. Apenas mantendo sua fala através da articulação de sua boca, conforme descreve o personagem do livro. Este silenciar do mundo que no livro vem desde a queda de Alberto, no filme é deslocado para o momento em que os dois personagens estão em frente ao mar. O mar e todo os outros sons vão saindo em fade e ouvimos apenas a respiração de Alberto. Este

159 AMARAL, Suzana. Hotel Atlântico, São Paulo - Roteiro Cinematográfico, 2007 
recurso faz com que o espectador se aproxime ainda mais do personagem principal, mas não se pode dizer que esta opção possa ser lida como a perda de audição descrita pelo personagem do romance.

Este bloco se inicia com Sebastião cantarolando, som este sugerido já no livro e mantido no roteiro. Ele canta uma música que parece ser inventada por ele. Temos nesta cena, mais uma vez em destaque, o som da água da torneira correndo na pia. Os ruídos produzidos pelos personagens, também, sempre em destaque, como o pulo de Alberto e os sons da gilete raspando no rosto e depois batendo na pia. Ao fundo um ambiente baixo, com alguns passarinhos.

Quando Alberto cai no chão, estão, mais uma vez em evidência, todos os ruídos produzidos pelo elenco. Aproveitando-se do fato que passam do banheiro para o quarto, o som da torneira é tornado quase inaudível, mas é mantido ao fundo. Não há nenhuma alteração no registro do som neste momento. este momento, podemos ver a articulação exagerada da boca de João Miguel, pensada para que a fala não fosse audível.

Os dois personagens saem do quarto, com Sebastião carregando Alberto. Quando a câmera passa para o exterior, passamos a ouvir o ambiente com passarinhos com mais intensidade e o som grave do mar ao fundo. Ao contrario do som que não reproduz a subjetividade do personagem, a câmera nesta seqüência assume o ponto de vista de Alberto. Trata-se de uma câmera na mão e apontada para o céu, reproduzindo o ângulo de visão de Alberto sendo carregado. No roteiro podemos ver que esta passagem havia sido pensada para ser editada em total silêncio. No entanto, escutamos o som do mar crescendo, à medida que se aproxima da praia, com a presença no som de aves marinhas. Está em evidência a respiração ofegante de Sebastião e os passos deste na 
areia. Eles se sentam em frente ao mar. A presença dos dois personagens é mantida, até que todos os sons vão sumindo em fade e o mar silencia. Ouvimos apenas a respiração de Alberto. Corte para o plano do mar contra os rochedos, no qual o som mar entra com potência e invade todo o ambiente. Ainda sobre este plano do mar, inicia-se o mesmo apito de navio da Sequiência 8 analisada acima. Este som do apito de navio chama a passagem para a cena de Alberto no quebra mar e o filme termina com a repetição desta seqüência. $\mathrm{O}$ apito do navio volta aqui com outra carga emocional. Ele fecha o ciclo iniciado por Alberto, ao mesmo tempo que deixa tudo em suspensão. Portanto vale reiterar que este talvez seja o som mais importante do filme todo, por construir com exatidão a emoção que a cena provoca e que estão presentes na busca angustiante de Alberto. 


\section{3 - A VIA LÁCTEA}

\subsection{1- A obra em aberto}

Iremos analisar algumas etapas ou movimentos que julgamos relevantes para o processo de realização da obra A Via Láctea, levando em consideração aspectos que desenvolvemos anteriormente. Trataremos aqui do processo de escrita do roteiro a partir de obras que inspiraram a diretora, sem que no entanto, o roteiro possa ser considerado uma adaptação literária. Abordaremos o processo de pré-produção e as decisões que foram tomadas nesta etapa do filme. Analisaremos também a direção de atores, segundo parâmetros fornecidos em conversas, pela própria diretora.

O processo de criação do filme A Via Láctea de Lina Chamie demonstra como uma obra pode permanecer em aberto para quem a está fazendo e ainda assim, seguir um planejamento e agenciar elementos para sua concretização. Veremos ao longo desta análise os caminhos, aberturas, bifurcações pelos quais o filme passou ao longo de sua criação, reiterando, a cada momento, que a obra se faz, como um acontecimento; a obra se refaz a cada instante, conforme vai sendo feita.

O diretor Carlos Nader, na ocasião da estréia de seu filme $O$ Homem Comum $^{160}$, afirmou $^{161}$ que em determinado momento da realização de um filme, a obra se desvincula de seu criador e ganha vida própria. A própria obra passa a conduzir seu autor ao longo de seu processo. A obra mostra seus caminhos e o autor a segue, numa eterna busca pela essência que lhe é própria.

160 NADER, Carlos. O Homem Comum, JÁ Filmes, São Paulo, 2014

161 NADER, Carlos. Depoimento em 11 de abril de 2014 
Quando refletimos sobre estas palavras em relação ao processo de realização de documentários, parece-nos evidente que o documentário possui maior abertura em relação à grande maioria dos filmes de ficção. No entanto, no processo de realização de uma ficção, tendemos a considerar que a obra segue uma narrativa concebida anteriormente ao momento de filmagem, como se o diretor pudesse de fato ter controle absoluto sobre o que está criando. No entanto, a afirmação de $\mathrm{Nader}^{162}$, nos leva a pensarmos nos muitos diretores que se deixam conduzir em suas escolhas, por evidências que a própria obra apresenta.

Esta visão da criação vem ao encontro do que esboça Blanchot em L'espace Littéraire $^{163}$, no que diz respeito à noção de que a obra contém o artista e não o contrário. Mesmo que a obra parta do artista e necessite deste para existir, em dado momento, ela se desvincula de seu autor para pertencer ao mundo. E isso ocorre, não apenas no momento em que é declarada pronta por seu autor. Seja em qualquer estágio, uma vez iniciado este processo de realização, a obra está no mundo e passa a sofrer influência de sua época e acontecimentos pertencentes a esta. No caso de um filme que exige vários colaboradores, ela passa por diversas mãos e mentes, é modificada a todo instante, por todos que a tocam.

A abertura da qual falamos em A Via Láctea ${ }^{164}$ percorre a obra toda, como um fio condutor. Estamos tratando aqui da trajetória do personagem principal Heitor, interpretado por Marco Ricca, o qual o filme narra seu atropelamento, de forma ambígua e não linear. Durante diversas etapas da escrita do roteiro a diretora hesita entre a morte deste personagem ou sua sobrevivência. A dúvida permanece durante todo

\footnotetext{
162 NADER, Carlos. Depoimento em 11 de abril de 2014

163 BLANCHOT, Maurice. L'espace Littéraire, Paris, Éditions Gallimard, 1955

164 CHAMIE, Lina. A Via Láctea, São Paulo, Girafa Filmes, 2007
} 
o período de pré-produção e filmagem, até o momento em que duas versões para o final são filmadas e finalmente apenas na montagem é que a decisão derradeira será tomada. Analisaremos mais detalhadamente como este processo se deu e de que forma a abertura foi incorporada e tratada, ao longo de todo este processo.

Devemos dizer, no entanto, que apesar de o processo todo ser permeado por uma questão em aberto, a diretora segue um planejamento ao dirigir seu filme. Tendo esta pesquisadora acompanhado pessoalmente os momentos de pré-produção assim como as filmagens e a montagem, e retificando nosso conhecimento a partir da comparação do roteiro com o filme montado, podemos afirmar que o roteiro deste filme é estruturado como uma partitura que é seguida, com poucas variações, no momento da filmagem e posteriormente na montagem. Algumas cenas deixaram de integrar o filme, no momento da montagem por não se mostrarem satisfatórias à diretora. Mas, pode-se dizer, que todo o filme é previsto no roteiro, da qual parte a elaboração da mise-enscène. Até mesmo sua indecisão em relação ao final aparece escrita de maneiras diferentes em diferentes versões do roteiro.

Imagens documentais, que parecem ter sido captadas ao acaso, estão expressas nas seqüências escritas. Lina Chamie vai em busca das imagens que pré-concebeu no roteiro, inspiradas por São Paulo, cidade sobre a qual a diretora escreve. Ao filmar a cidade, esta partitura já está articulada e segue um encadeamento onde cada peça vai sendo somada, como instrumentos em uma orquestra.

O processo de criação de $A$ Via Láctea se inicia a partir de algumas referências literárias e musicais citadas por Lina Chamie, mas que no entanto, não foram 
diretamente transpostas do texto para o filme. São pequenas faíscas de inspiração, às quais a cineasta seguiu para conceber seu roteiro.

Jacques Rancière em As Distâncias do Cinema ${ }^{165}$ traz uma reflexão sobre a transposição da literatura para o cinema que parece dialogar com a forma como Lina Chamie trabalha com outras obras: "O problema, então, não é apenas inventar, com imagens em movimento e os sons gravados, procedimentos literários."166

Em relação às fontes literárias que serviram de ponto de partida para a criação do roteiro e do filme, podemos observar como camadas vão se sobrepondo, até que, finalmente, pouco se reconheça do ponto de partida. Não que se busque apagar a obra referencial como ponto de partida, pois em alguns momentos ela está lá, colocada de forma explícita. O que parece, no entanto, interessar à diretora é como forma se apropria destas referencias e como, a partir daquela inspiração inicial pode se configurar uma nova obra. Sendo que, para isso, em alguns momentos a obra literária sofrerá total transformação, em outras ela vai aparecer da forma como foi escrita. A multiplicidade de pontos de partida, é preservada como característica do filme. A trama se compõem a partir de cenas diversas, que surgem umas das outras, como um fio de memória que vem sendo desenrolado.

Apesar de costurar memórias pessoais a uma série de outras referências, Chamie sempre deixa claro que o roteiro ou o mesmo o filme não tratam de sua vida pessoal. Ela apenas se utiliza deste material como uma fonte de inspiração. Mesmo que algumas passagens do filme tenham origem em lembranças bastante caras à realizadora, como a despedida de sua mãe, Chamie prefere tratar estes momentos em sua obra como homenagens às pessoas ali lembradas. Ao transpor estas situações para o roteiro, não

165 RANCIÈRE, Jacques. As Distancias do Cinema, Contraponto, Rio de Janeiro, 2012

166 Ibid., pg. 55 
existe um compromisso em manter intocadas suas lembranças, mas sim de transformálas em algo a serviço do filme, que este possa ser o portador de um sentimento e não um diário filmado.

Tomaremos como exemplo a criação do personagem Heitor, que tem seu nome inspirado por um esgrimista, praticante desde os 8 anos de idade, que Lina Chamie acompanhou ao longo da vida. A profissão do personagem é escritor e professor, como o pai da diretora e as lembranças que ele vive ao lado da mãe, no filme, se inspiram de certa forma, em lembranças da própria diretora, vividas ao lado de sua mãe. Sendo assim, neste personagem está contida a síntese de várias camadas, que vão se adicionando umas às outras, ao longo do seu processo de criação.

Quando indagada sobre o motor de criação para este filme, Chamie remonta a um episódio de sua vida, no qual, sofrendo de uma pericardite, precisou permanecer por diversas semanas em repouso absoluto, o que à levou a ler e reler algumas obras, as quais, justapostas, inspiraram à diretora no início da elaboração do roteiro. As obras lidas neste período que marcaram o lampejo inicial de criação da obra foram A Divina Comédia $^{167}$, As Aventuras de um Automobilista ${ }^{168}$ de Ítalo Calvino e principalmente o poema Campo de Flores $^{169}$ de Carlos Drummond de Andrade. Outro motivo para citar tal condição de saúde, se deve ao fato de que as imagens resultantes de seus exames de cintilografia do coração, evocaram, para a diretora, as imagens realizadas por telescópios espaciais e acabaram integrando o filme, unindo, desta maneira duas temáticas da obra.

\footnotetext{
167 ALIGHIERI, Dante, MOURA, Vasco Garça. A Divina Comédia, Landemark, São Paulo, 2011

168 CALVINO, Italo. Os Amores Difíceis, São Paulo, Companhia das Letras, 1996

169 ANDRADE, Carlos Drummond. Reunião, Rio de Janeiro, José Olímpio, 1978, 9ª Edição, pg. 178
} 
Posteriormente, outras obras literárias, como o poema Chuva Interior ${ }^{170} e$ teatral, como As Bacantes ${ }^{171}$ passaram a integrar o filme. Lina Chamie segue um caminho bastante singular ao se apropriar destas obras e assim gerar o fio condutor para o roteiro de A Via Láctea. Devemos, de fato, falar em apropriação destas obras não adaptação literária para o cinema, pois não existe uma preocupação em seguir o enredo sugerido por qualquer uma delas. O que Lina faz é extrair imagens destes textos e transformá-las em inspirações para cenas de seu filme. E, no caso da peça teatral, incorporá-la ao próprio enredo do filme.

O filme, nasceu, segundo Lina Chamie, do poema ${ }^{172}$ de Drummond. O "amor no tempo de madureza" ${ }^{173}$ inspira a criação do casal de personagens Heitor e Júlia, personagem feminina principal de A Via Láctea, interpretado pela atriz Alice Braga. Heitor como o poema sugere é um homem que já chegou à idade madura e Júlia é uma mulher ainda jovem. A diferença de idade entre os dois se torna um gerador de conflito que dá origem à trama do filme. O poema de Drummond aparece ainda lido algumas em seqüências, ao longo do filme. Nas primeiras versões do roteiro, o filme se chamaria Onde Não Há Jardim $^{174}$ em alusão a um verso deste mesmo poema.

Da Divina Comédia ${ }^{175}$, vemos, na segunda cena do filme o verso inicial do poema: "No meio do caminho desta vida me vi perdido, numa selva escura sem sol e sem saída", verso este que sintetiza o arco narrativo do personagem principal, Heitor. O verso aparece em lettering, em um painel de vídeos publicitários, que existia na cidade

\footnotetext{
170 CHAMIE, Mário. A Quinta Parede, Nova Fronteira, Rio De Janeiro, 1976

${ }^{171}$ Peça teatral As Bacantes, livre adaptação da tragédia de Eurípedes, por José Celso Martinez Correa e a Companhia Teatral Teat(r)o Ofincina Uzyna Uzona

172 ANDRADE, Carlos Drummond. Reunião, Rio de Janeiro, José Olímpio, 1978, 9ª Edição, pg. 178

173 Ibid.

174 Ibid.

175 ALIGHIERI, Dante, . A Divina Comédia, tradução de MOURA, Vasco Garça, Landemark, São Paulo, 2011
} 
de São Paulo, no momento das filmagens. A trajetória do personagem Heitor, no entanto, percorre o caminho inverso ao de Dante $^{176}$, que vai do inferno ao paraíso. Heitor sai de sua casa enquanto ainda é dia e transita pela cidade durante o entardecer, até que fique de noite. Quanto mais ele busca se aproximar de sua amada, mais ele se afasta de seu caminho, que se torna mais e mais escuro.

Do conto de Calvino resta a linha narrativa do condutor que tenta chegar à sua amada, depois de uma briga por telefone. Veremos de que maneira este enredo será explorado e transformado ao longo do processo de criação do filme. Podemos observar como o seguinte trecho dialoga com as cenas iniciais, assim como a motivação do personagem Heitor de chegar ao seu destino amoroso.

"Peguei o carro num rompante, depois de uma briga telefônica com Y. Moro em A, Y mora em B. Eu não tinha previsto ir me encontrar com ela esta noite. Mas em nosso telefonema diário, nos dissemos coisas muito sérias; no fim levado pelo ressentimento, eu disse a Y que queria terminar nossa relação; Y respondeu que não se importava com isso, e que ia logo telefonar para Z, meu rival. Nesta altura um de nós dois - não me lembro se ela ou eu mesmo - desligou. Não havia passado um minuto e eu já me dera conta de que a causa da nossa briga não era nada em comparação com as conseqüências que estava provocando. Ligar novamente para Y seria um erro; o único modo de resolver a questão era dar uma corrida a B e ter uma explicação com Y cara a cara." $" 177$

No roteiro, identificamos a cena descrita acima; a história de X que dirige de A para B, para encontrar Y. A motivação de Heitor é uma briga com Júlia ao telefone. Em meio à briga, Heitor descobre que Júlia saiu com amigos, entre os quais, Thiago, antigo rival. O ciúme que sente de seu rival Thiago, o antagonista de Heitor, interpretado pelo ator Fernando Alves Pinto, faz com que Heitor, arrependido da briga, saia enfurecido, sai de carro, no horário do rush, com o intuito de ficar frente a frente com sua amada e

\footnotetext{
176 ALIGHIERI, Dante, . A Divina Comédia, tradução de MOURA, Vasco Garça, Landemark, São Paulo, 2011, Dante é um dos personagens do poema épico

177 CALVINO, Italo. Os Amores Difíceis, São Paulo, Companhia das Letras, 1996, 124
} 
assim promover a reconciliação do casal em direção à Júlia, na esperança que esta não tenha ligado para Thiago, como afirmou que faria.

Em uma das primeiras versões do roteiro, ainda sem diálogos e intitulado Onde Não Há Jardim ${ }^{178}$, o personagem Thiago é chamado de Z, em clara alusão ao conto de Calvino, como podemos observar na transcrição de uma seqüência:

\section{"SEQUENCIA 6 - TEATRO OFICINA - INT. - NOITE}

Estamos assistindo à peça As Bacantes, na encenação do Teatro Oficina de Zé Celso. Heitor na segunda fila, quase desesperado. A sua frente, um distinto espectador é atacado pelas bacantes, que tiram a sua roupa e começam a lambê-lo. As atrizes fazem menção de vir em direção ao nosso herói. Ele sua. As atrizes avançam. Ele recua, na cadeira. Apesar de todas as suas preces, o inevitável acontece: elas o abordam e violentamente começam a tirar sua roupa. Ele resiste. Fecha os olhos na esperança de que elas desapareçam. Heitor abre os olhos novamente. Elas não desapareceram. Fade para preto." 179

Apreendemos, ao longo do filme que o mesmo sentimento que anima Heitor em relação à Júlia é traduzido pelo personagem narrador do conto de Calvino:

"Percebo que ao correr para $\mathrm{Y}$ o que mais desejo não é encontrar $\mathrm{Y}$ ao fim da minha corrida: quero que seja Y que esteja correndo para mim, esta é a resposta de que preciso, ou seja, preciso que ela saiba que estou correndo para ela, mas ao mesmo tempo preciso saber que ela está correndo para mim." 180

O tema da travessia, também está presente em A Via Láctea. Tratado inicialmente de maneira concreta, através dos motoristas presos no engarrafamento, que buscam atravessar um espaço concreto da cidade de São Paulo, vai, aos poucos assumindo outras conotações ao longo do filme, se transformando numa metáfora para a própria travessia da vida, ou, como aparece em algumas traduções para o português, da

\footnotetext{
178 ABIB, Aleksei, CHAMIE. Lina, Onde Não Há Jardim, Roteiro em desenvolvimento que posteriormente deu origem ao filme A Via Láctea. Não foi preservada a data precisa do documento; imagina-se que tenha sido redigido entre 2003 e 2004

179 Ibid.

180 CALVINO, Italo. Os Amores Difíceis, São Paulo, Companhia das Letras, 1996, 126
} 
A Divina Comédia, ${ }^{181}$ a jornada. A mescla de referências e o acréscimo de eventos externos, dissociam, desta forma, a story line do filme, daquela do conto de Calvino ${ }^{182}$, fazendo com que este seja apenas um pano de fundo para outros acontecimentos. Em determinado momento, as narrativas deixam de ser correlatas. O filme segue seu próprio caminho, com uma fabulação própria. Entretanto, mais do que seguir uma linha narrativa, Lina Chamie se apropria das imagens que o conto sugere, e as recria na forma de imagens, sem que exista entre estas uma correspondência em termos de sentido. As imagens sugeridas, aparecem como fragmentos de uma nova narrativa, dotadas de sentido próprio dentro da semântica do filme.

O roteiro é uma costura de elementos, de fragmentos de outras obras, uma verdadeira leitura antropofágica, nos quais podemos destacar algumas obras citadas, enquanto outras se dissolveram para ser disseminadas por todo o filme. Não importa para a diretora o ponto de partida e sim a forma final do filme, que já vem sugerida no roteiro.

Além das referências literárias, musicais e teatrais, Lina se vale, como já referido, de memórias pessoais, como o falecimento de sua mãe, para compor a trama de A Via Láctea, fato este que, segundo a diretora, levou-a a buscar um colaborador para o desenvolvimento do roteiro. A diretora acreditava que um co-roteirista teria maior distanciamento dos episódios pessoais que são abordados dos quais tratava, não ficando preso aos fatos em si, mas colocando-os a serviço do filme. O colaborador para na escrita do roteiro foi Alksei Abib.

${ }^{181}$ ALIGHIERI, Dante, MOURA, Vasco Garça. A Divina Comédia, Landemark, São Paulo, 2011

182 CALVINO, Italo. Os Amores Difíceis, São Paulo, Companhia das Letras, 1996 
A primeira versão do roteiro, ainda com o título de Onde Não Há Jardim ${ }^{183}$ obteve o prêmio de desenvolvimento de roteiro $1^{o}$ Taller de Desarollo de Proyectos Cinematográficos Iberoamericanos ${ }^{184}$ da Casa de America e Fundación Carolina, em Madrid e os dois roteiristas participaram de uma oficina de 8 semanas na qual o roteiro sofreu profundas transformações. Abib e Chamie tinham, em sua primeira versão do roteiro tentado preservar a vida do protagonista.

Vítima de um atropelamento na trama, Heitor conseguiria sobreviver no final. Segundo Chamie, durante a oficina de roteiro, no qual os envolvidos discutiam os projetos de todos os participantes, o grupo se dividia entre os que achavam que Heitor não deveria sobreviver e os que achavam que ele devia ser salvo no final, alegando que desejavam um final feliz para os personagens.

Ao comparar algumas versões do roteiro em fase de trabalho, podemos observar as diferentes formas encontradas pelos roteiristas para o final da trajetória de Heitor. Como os roteiros não possuem datas, não podemos precisar em que momentos foram escritos. Sabemos apenas que se tratam de etapas de trabalho anteriores à pré-produção:

\section{Versão 1:}

"SEQUÊNCIA 64-AMBULÂNCIA-RESGATE - INT. - NOITE

Silêncio. Apenas ouvimos o som de respiração humana.

Júlia chora abraçando Heitor e dizendo que o ama. Bruscamente ele volta a respirar, engasgado.

Heitor acorda na ambulância-resgate."

\footnotetext{
183 ABIB, Aleksei, CHAMIE. Lina, Onde Não Há Jardim, Roteiro em desenvolvimento que posteriormente deu origem ao filme A Via Láctea. Não foi preservada a data precisa do documento; imagina-se que tenha sido redigido entre 2003 e 2004

184 Prêmio concedio pela Casa de América Fundación Carolina em Madrid, Espanha, com objetivo de apoiar e fortalecer projetos de escrita, voltados para Penísula Ibérica e América Latina
} 
Versão 2:

"SEQUENNCIA 75 - AMBULÂNCIA-RESGATE - INT. - NOITE

Equivale a seqüência 73.

Silêncio total. Júlia chora abraçando Heitor.

JÚLIA (chorando, ela fala mas desta vez não a ouvimos, apenas vemos o movimento de seus lábios)

- Heitor, eu estou aqui!

Heitor permanece inconsciente.

$\operatorname{HEITOR}(O F F)$

...Agora eu entendo tudo...

Entre o céu e a terra o amor continua. Fazemos parte deste fio invisível e continuo da vida. Perdas se transformam. As coisas lindas, muito mais que findas, essas ficarão.

Sinto que amanhece, quero viver."

\section{Versão 3:}

\section{"SEQUÊECIA 75 - AMBULÂNCIA-RESGATE - INT. - NOITE}

Equivale a seqüência 73.

Silêncio total. Júlia chora abraçando Heitor.

JÚLIA (chorando, ela fala mas não ouvimos, apenas vemos o movimento de seus lábios)

- Heitor, eu estou aqui!

Heitor não acorda." 


\section{Versão 4:}

\section{"SEQUÊECIA 73 - AMBULÂNCIA-RESGATE - INT. - NOITE}

Silêncio. Apenas ouvimos o som de respiração humana.

Júlia chora abraçando Heitor.

JÚLIA (chorando)

- Heitor, eu estou aqui!

Heitor abre os olhos na Ambulância-Resgate."

A versão 4 é a que permanece no roteiro, que posteriormente será apresentada à equipe de filmagem e atores. Entre as diferentes versões, podemos notar a hesitação sobre o que aconteceria com o personagem. Lina Chamie assume que ela e Aleksei Abib estavam empenhados em salvar a vida de Heitor. Preocupavam-se, no entanto, se não pareceria demasiado piegas que no final ele pudesse ser salvo pelo amor de Júlia. Mas ao mesmo tempo, não conseguiam abrir mão da vida do personagem, parecia-lhe impossível matá-lo.

Antes de realizar o Taller de Desarollo de Proyectos Cinematográficos Iberoamericanos, Lina afirma que ela e Alksei já possuíam uma intuição sobre esta questão. No entanto, enquanto trabalhavam apenas os dois no roteiro, sentiram-se livres para poupar a vida do personagem, como observamos na versão 1 do roteiro, apresentada acima, na qual Heitor volta à vida dentro da ambulância, depois de voltar a respirar engasgado.

Durante a oficina, os tutores colocaram como um ponto de que deveria ser modificado no roteiro, pois parecia-lhes um final inverossímil, sendo que o filme inteiro trazia uma mensagem de que Heitor estava morrendo, após o atropelamento. $\mathrm{O}$ fato de 
ele rever memórias da infância, a despedida da mãe, o ladrão que rouba-lhe o relógio dizendo-lhe que ele não precisa mais disto e finalmente o atropelamento da cachorrinha. Da mesma forma, as referências musicais, que já faziam parte do roteiro, reiteravam esta mensagem: o Quarteto de Cordas em Ré Menor de Schubert é colocado em uma das versões do roteiro como leitmotiv do personagem Heitor. Trata-se do tema A Morte e a Donzela. Também em dado momento do filme, após o atropelamento da cachorrinha, ouve-se, sobre imagens do centro de São Paulo à noite, o Réquiem de Mozart, acompanhado de um texto off sobre a cachorrinha Laika que foi lançada ao espaço.

No entanto, algumas modificações são feitas. Na versão 2, Heitor permanece inconsciente, mas um texto em off reafirma seu desejo de viver. Este roteiro é o que possui maior ambigüidade sobre os fatos, pois ele permanece de olhos fechados, mas o texto indica uma sobrevida para o personagem.

Já na versão 3, aqui apresentada, Heitor não acorda. O texto off desaparece, temos apenas a personagem Júlia que chora e fala, sem que sua voz seja ouvida, "Heitor, eu estou aqui." 185 Este é o primeiro roteiro em que a diretora e roteirista assumem como possibilidade a morte de Heitor. Em nenhum outro documento referente ao filme, este final aparece. Como já foi dito, havia uma resistência da diretora em transformar A Via Láctea em um drama.

A insistência da dupla de roteiristas em salvar a vida do personagem culmina na versão 4 do roteiro, ainda com o titulo Onde Não Há Jardim, mas com a alteração de que na cena final, Júlia segura a mão de seu namorado e após dizer a mesma frase que

185 ABIB, Aleksei, CHAMIE. Lina, Onde Não Há Jardim, Roteiro em desenvolvimento que posteriormente deu origem ao filme A Via Láctea. Não foi preservada a data precisa do documento; imagina-se que tenha sido redigido entre 2003 e 2004 
figura na versão 3: "Heitor, eu estou aqui."186, Heitor abre os olhos. Depois desta modificação, o roteiro não sofreu mais alterações a não ser o título do filme, passando a se chamar, definitivamente, A Via Láctea.

Durante toda a pré-produção, equipe e elenco trabalharam seguindo a versão 4 do roteiro, como já foi dito. A informação que se tinha é de que o personagem abriria os olhos no final. Retomando a noção de que a leitura que cada membro da equipe realiza de um roteiro, cria ressonâncias pessoais que resultarão em suas colaborações criativas, atentamos para o fato de que a leitura de um final divergente do apresentado, condiciona o entendimento da obra como um todo. Para os atores, sobretudo, acreditamos que possa causar uma influência significativa, se pensarmos nas construções emocionais que estes elaboram a partir do texto, para criar seus personagens. Sendo assim, não se trata apenas entre a escolha por dois finais diferentes, que poderão ser resolvidos em um único plano na hora da filmagem, mas do entendimento da narrativa como um todo que se modifica conforme este escolha é feita: temos de um lado um filme sobre a morte; de outro um filme sobre a permanência após a iminência da morte.

Durante a filmagem, diretora, equipe e elenco permaneceram trabalhando com a versão oficial do roteiro de que o personagem sobreviveria. No entanto, no momento de filmar a cena no interior da ambulância, Lina comunicou aos seus atores que faria as duas versões. Provavelmente, por continuar assombrada pela dúvida que as discussões na oficina de desenvolvimento de roteiro haviam suscitado.

\footnotetext{
186 ABIB, Aleksei, CHAMIE. Lina, Onde Não Há Jardim, Roteiro em desenvolvimento que posteriormente deu origem ao filme A Via Láctea. Não foi preservada a data precisa do documento; imagina-se que tenha sido redigido entre 2003 e 2004. - Versão 3
} 
A decisão final, viria apenas com a montagem. Quando se chegou ao final do primeiro corte, a diretora se deu conta de que a versão na qual Heitor sobrevive, não possuía a mesma força que a versão na qual ele não sobrevive. Durante esta etapa de trabalho, as duas versões foram colocadas em prática. A diretora assistiu às duas versões e chegou à conclusão que o fato de o personagem ressuscitar no interior da ambulância, esvaziava o significado do plano seguinte, do céu estrelado, construção esta que vinha sendo costurada ao longo de todo o filme, com alusões de textos e imagens sobre o espaço, o céu e as estrelas. Também a construção sobre a morte do personagem, que havia sido forjada ao longo do filme, ficaria sem sentido, sendo desconcertante que ele sobrevivesse ao final.

Quando indagada, a posteriori, sobre sua decisão de filmar os dois finais, Lina afirma que possuía, desde sempre, esta intuição, de que o destino de Heitor seria morrer. Mas que lhe era custoso admitir este final para seu personagem. Sendo assim, preferiu buscar outras alternativas, mesmo sabendo que não poderia ignorar um chamado da própria obra. Ao terminar a montagem, a diretora justificou-se "O filme pediu que fosse assim." 187

No âmbito de sua criação, o artista é livre para decidir. No caso do longa metragem A Via Láctea, sabemos que não havia nenhuma obrigação contratual, nem de outra natureza, ou mesmo pressões externas, que pudesse condicionar a escolha da diretora. As escolhas do artista, em relação à sua obra, partem de um pacto que existe entre estes dois pólos, o artista criador e a obra criação. Deparamo-nos com o paradoxo exposto por Blanchot em L'espace Littéraire ${ }^{188}$ de que a obra parte do artista, mas ao

187 Chamie, Lina. Depoimento ao final da Montagem de $A$ Via Láctea dez/2006 188 BLANCHOT, Maurice. L'espace Littéraire, Paris, Éditions Gallimard, 1955 
longo do seu processo de criação, é a obra que contém o artista e não o contrário. Blanchot considera, ainda, que a obra fala através do artista, ele é um dos instrumentos para que se torne concreta sua manifestação.

Em relação ao filme A Via Láctea podemos dizer que a obra apresentou evidências à sua diretora e esta não as pode ignorar, seguindo, assim, o que a obra lhe ditava, durante seu processo de realização. A concepção de poética como a arte que se faz, à medida que é feita, discutida por Passéron ${ }^{189}$, e antes dele, por Paul Valéry ${ }^{190}$, justificam-se a partir da observação de processos como estes, nos quais podemos observar os caminhos da criação se fazendo à medida que o artista caminha em seu processo de realizar algo.

\subsection{2 - Estratégias de filmagem}

A pré-produção do filme teve início em meio a incertezas, devido ao orçamento restrito que a obra possuía para sua realização. Incertezas financeiras, que trouxeram como consequiência a necessidade de readequação estética da obra e que resultou em uma completa transformação do projeto.

O filme havia sido contemplado em 2004 com o prêmio Fomento ao Cinema Paulista 2004 - Governo do Estado /Secretaria da Cultura com um valor que equivalia a um quinto do valor orçado para a realização completa do filme, incluindo sua finalização. Temendo não captar outros recursos para realizá-lo e correndo o risco de perder os que já tinha em mãos, por conta do prazo estipulado para utilização dos

\footnotetext{
189 PASSERON, René. Pour une philosophie de la Création, Editions Klincksieck, 1985
} 190 VALÉRY, Paul. L'Invention Esthétique, In Oeuvres I, Paris, Gallimard, 1957 
mesmos, a diretora Lina Chamie assumiu, então, que faria os esforços necessários para conseguir filmar com os aportes que possuía naquele momento.

Muitas vezes o orçamento ou os meios de produção disponíveis não alcançam as ambições estabelecidas e, nem sempre há a possibilidade de se adaptar o filme aos recursos disponíveis, sem comprometer o objetivo que se deseja alcançar e acabe por se fazer um filme muito diferente do imaginado. De certa forma, todos os filmes passam por alguma transformação, ou readequação à realidade, ao deixar de ser apenas imagens mentais de um cineasta. Os filmes ao ficarem prontos são frutos de acontecimentos que se produzem ao longo de sua feitura.

No caso de A Via Láctea, as implicações, como veremos, incluíram mudar a intenção de se filmar em $35 \mathrm{~mm}$ para se filmar em mini-dv e depois fazer um transfer para película apenas em sua cópia final. Lina Chamie afirma que ao fazer esta modificação, principalmente pautada pelas limitações financeiras que o filme vivenciava, terminou por encontrar o formato que mais se adequava ao projeto que desejava realizar. A diretora afirma que o fato a de câmera mini DV ser mais leve e portanto, mais fácil de ser manuseada permitiu a ela elaborar os planos, os quais vinha pensando e não tinha em mente como concretizar .

Com esta câmera, foi possível criar um corpo a corpo com o ator e com o trânsito de São Paulo, "bastante selvagem", segundo a diretora. As dimensões da câmera, permitiram que esta estivesse o tempo todo ao lado dos atores, dentro do carro, no trânsito. Trânsito este, que não foi encenado; os atores dirigiram os próprios carros de cena em meio aos carros que de fato trafegavam pelas avenidas. 
A escolha da mini DV, fez também com que a diretora optasse por utilizar película em algumas cenas, pontuadas ao longo do filme, com a intenção de criar diferentes texturas e em alguns momentos o uso de câmera lenta, com o suporte da película. Esta utilização de diferentes suportes faz parte da gama de recursos que tornam-se ao longo do filme interferências na percepção do espectador, contribuindo para tornar a linguagem cinematográfica aparente, ou nas palavras de Ismail Xavier ${ }^{191}$, reforçando sua opacidade.

Em A Via Láctea, Lina Chamie acabou por adotar duas linhas de ação. Uma que dizia respeito às cenas sobre as quais podia ter algum controle, como as realizadas em locação, contando apenas com a presença de seus atores. E outra em relação às cenas que ela chamava de semi documentais, pois tratavam de inserir os atores em situações sobre as quais não havia controle dos demais elementos, como era o caso do trânsito da cidade e a encenação no Teatro Oficina.

Esta estratégia facilitou para a diretora o entendimento de como abordar as situações de filmagem: para os momentos em que a diretora poderia ter algum controle sobre a situação, ela criaria uma decupagem de antemão. Já para os momentos semi documentais, a diretora optaria por deixar a câmera solta nas cenas em que haviam muitos elementos. E haviam ainda as situações em que estava com seus atores conduzindo o próprio carro de cena e a câmera ficaria, em alguns momentos, presa ao vidro do carro, ou seja, havia um pré-enquadramento, mas não um controle absoluto sobre o que poderia aparecer no quadro.

191 XAVIER, Ismail. O Discurso Cinematográfico: Opacidade e transparência, São Paulo, Paz e Terra, 2005 - $3^{\mathrm{a}}$ edição 
Analisaremos algumas das implicações nas filmagens e no resultado obtido, decorrentes desta estratégia assumida por Lina Chamie, em relação à maneira como decidiu realizar seu filme.

É comum que diretores concentrem seus esforços em buscar conhecer assuntos os quais não dominam para solucionar passagens em seus filmes. Na época em que escrevia o roteiro, Lina havia se consultado junto ao corpo de bombeiros, sobre algumas dúvidas acerca de procedimentos realizados em socorros a vítimas de trânsito. Esta primeira entrevista resultou em aprendizados direcionados a solucionar problemas relativos ao roteiro, como por exemplo de que uma ambulância deve estacionar para que seja acionado o aparelho desfibrilador. Tal procedimento está presente na seqüência em que a ambulância estaciona em frente a uma banca de jornal, na qual está o personagem Thiago. Também decorrente deste contato com o corpo de bombeiros, os roteiristas introduziram alguns termos técnicos que estes costumam empregar como RCP para se referir ao procedimento de utilização do desfibrilador para casos de paradas cardíacas.

Para as filmagens, a diretora conduziu, junto a bombeiros e paramédicos uma pesquisa sobre o atendimento a vítimas de atropelamento, para elaborar uma cena verossímil quanto ao atropelamento e primeiros socorros de seu personagem principal. Para Lina Chamie, esta cena deveria ter um tom realista, sem que houvesse dramatização do ocorrido, pois a cena, mesmo sendo fictícia iria dialogar com o tom das filmagens assumido para as cenas de trânsito, uma vez que fazia parte deste bloco do filme, como descrito acima. Além destes fatores conceituais, para sua realização, era preciso prever o tempo de filmagem desta levando em conta o quê e como iria ser filmado. 
Foi conseguido pela produção que o SAMU emprestaria uma ambulância para as filmagens, tanto para a cena do resgate, como para os momentos que a ambulância anda pelas ruas. A ambulância deveria ser conduzida por um dos profissionais que trabalha para a SAMU, por conta de questões de seguro do equipamento. A empresa de atendimento emprestaria também os uniformes.

Após uma reunião em que o SAMU prestou consultoria à diretora sobre os procedimentos padrão em casos de atropelamento, ficou decidido que não seriam recrutados atores para os papeis de paramédicos. Seriam os próprios paramédicos que realizariam a cena, como se estivessem de fato atendendo uma vítima no trânsito. Sendo assim, pensou-se a cena para o dia da filmagem, de forma a se utilizar duas câmeras mini dv, uma acoplada ao steady cam e uma segunda unidade de câmera, que buscaria registrar detalhes que não estivessem ao alcance da câmera principal. Isto foi pensado para que não se precisasse repetir muitas vezes as ações, uma vez que estava se filmando com não atores.

A diretriz dada aos dois paramédicos que se prestaram a participar do filme era que deveriam executar as ações como fazem normalmente, sem se preocupar com nenhum problema técnico que pudesse decorrer da filmagem. A equipe se encarregaria de procurar o melhor ângulo para filmá-los, sem interferir em suas ações. Eles não deveriam parar durante a ação, apenas se a diretora cortasse a cena. As únicas marcações dadas foram em relação ao posicionamento da ambulância, que começava a ação em movimento e deveria estacionar junto à vítima. Neste ponto, os paramédicos também auxiliaram na construção do desenho da cena, usando sua expertise para determinar qual seria a melhor forma de movimentação. 
No momento da filmagem, após posicionado o carro que atropela a vítima e definido o local onde seria estacionada a ambulância que chega logo depois que o socorro é acionado, pediu-se que fosse realizado um ensaio com os paramédicos e um membro da equipe, que serviria de stand in, para que a equipe técnica pudesse observar a movimentação e se posicionar para efeito de melhor captação da cena.

A cena foi rodada em tomada única. Toda a equipe que não estivesse executando nenhuma tarefa técnica no momento, como operação e assistência câmera ou captação de som, se colocou fora do campo de ação dos paramédicos, para que a câmera pudesse cobrir uma varredura de quase trezentos e sessenta graus. Mesmo a diretora ficou fora do set, observando a tudo pelo monitor de vídeo. O limite do campo de ação dos técnicos era dado pelo limite de extensão dos cabos de vídeo assist e som.

A consultoria prestada pelos paramédicos da SAMU se estendeu para além da cena acima descrita. As informações técnicas transmitidas por estes profissionais de saúde, se irradiaram para vários aspectos do filme.

A decisão de se filmar com os próprios paramédicos levou a diretora a optar por gravar os diálogos offs ditos no interior da ambulância com os próprio socorristas, o que implicou em uma mudança nos diálogos apontados pelo roteiro. As frases foram ditas no jargão que estes utilizam em seu trabalho, incorporando as siglas e termos técnicos próprios.

As informações sobre os tipos mais comuns de ferimentos em casos de atropelamento induziram também na escolha do figurino. Por conta do local onde se formaria a hemorragia, optou-se em utilizar uma camisa de cor clara e uma camiseta por baixo, para que pudesse ser cortada no momento da prestação de socorro. Como foi explicado pelos socorristas, não é tão comum que um atropelamento como estes, em 
que a vítima apenas colide com um automóvel, resulte em hemorragias externas tão significativas. No entanto, havia sido pensado por Lina Chamie, que a mancha de sangue aparente na roupa de Heitor seria o ponto de ligação entre seu atropelamento e o do cachorro, provocado por ele. Foi uma licença poética que a diretora empregou, para manter a coerência interna da obra.

A filmagem da peça As Bacantes ${ }^{192}$ exigiram uma série de estratégias que precisaram ser articuladas durante a pré-produção. Primeiramente, era um dado essencial ao roteiro que a cena se passasse na própria cede do Teatro Oficina, no bairro da Bela Vista em São Paulo, pois o filme busca dialogar com elementos da cidade de São Paulo, como as ruas que são vistas, a banca de flores ao lado do cemitério da Avenida Doutor Arnaldo, prédios da Avenida Paulista, entre outros que reconhecemos no filme. A existência da cena também estava condicionada à encenação da montagem da peça As Bacantes ${ }^{193}$, adaptada livremente por José Celso Martinez Correa e o grupo teatral Uzyna Uzona pela primeira vez em 1996, na cidade de São Paulo. Tratava-se de uma referência direta à encenação original do grupo, no qual eles escolhiam membros da platéia e os despiam frente ao público.

Em uma primeira reunião com Zé Celso, as condições foram colocadas e o diretor informou que faria uma consulta aos membros de sua companhia, para saber quais seriam os atores que poderiam participar. A maioria destes optou por contribuir com a remontagem da peça e haveriam ensaios para repassar a peça aos recém integrados à companhia.

192 Peça teatral As Bacantes, livre adaptação da tragédia de Eurípedes, por José Celso Martinez Correa e a Companhia Teatral Teat(r)o Ofincina Uzyna Uzona 193 Ibid. 
O primeiro problema levantado, foi em relação à platéia. Haveria a necessidade de se preencher as arquibancadas do teatro, como se de fato estivesse ocorrendo uma apresentação da peça. Com o orçamento de figurantes que o filme possuía, não seria possível reproduzir um teatro cheio. A produtora do Teatro alegou que para os atores da companhia, era importante a presença de público real e não somente de figurantes. Muitas vezes os figurantes estão preocupados em apenas seguir uma marcação e neste caso, para os atores da companhia, a interação com o público fazia parte deste espetáculo. Optou-se por agir em duas frentes: de um lado a produção de figuração do filme asseguraria a presença de cerca de 90 figurantes para a realização da cena. E em outra frente, a assessoria de imprensa do Teatro Oficia faria a divulgação da encenação do primeiro ato da peça As Bacantes ${ }^{194}$ junto ao público cativo da companhia. A entrada seria gratuita, mas todos que quisessem participar deveriam assinar um termo de cessão de uso de imagens para a produção do filme. Assim, garantiu-se que o teatro estivesse cheio o suficiente para realização da cena e com o público que a companhia teatral desejava.

Como já foi descrito, esta cena faz parte das cenas categorizadas pela diretora como aquelas em que haveria pouco controle sobre o que seria filmado. A companhia realizou um ensaio para a diretora e outras pessoas da equipe técnica, para que se pudesse pensar as estratégias de captação da cena.

Mais uma vez a opção da diretora foi por não causar nenhuma interferência sobre como a companhia deveria atuar. A única diretriz dada aos atores do Teatro Oficina é que deveriam realizar a cena do desnudamento com o ator Marco Ricca, que

194 Peça teatral As Bacantes, livre adaptação da tragédia de Eurípedes, por José Celso Martinez Correa e a Companhia Teatral Teat(r)o Ofincina Uzyna Uzona 
estaria sentado em um local determinado da platéia. O local fora determinado pela visibilidade que este possuía em relação ao palco.

Como não haveria interferência nas ações, para esta diária convocou-se três equipes de câmera e uma equipe de som adicionais. Desta forma, pretendia-se cobrir todos os detalhes durante a extensão da peça, sem que fosse necessária a repetição de ações. A equipe técnica ficaria posicionada no palco do Teatro Oficina, junto com a companhia em ação. Ao contrario de filmagens nas quais se pode ter um controle sobre a situação, a equipe do filme não deveria interromper a encenação em caso de problemas técnicos. A unidade de som ou imagem que constatasse algum senão, deveria se afastar do local da filmagem, para tentar solucionar o problema e retornar à cena.

O palco do Teatro Oficina é uma passarela, ladeada de arquibancadas dos dois lados. O público seria posicionado de forma a priorizar os enquadramentos para ação da peça. No dia da filmagem, montou-se uma bancada no lugar da bilheteria, para que as autorizações de uso de imagens fossem colhidas.

A filmagem transcorreu como previsto. Uma vez a figuração, tanto a contratada como a voluntária, tendo sido posicionada, os demais elementos foram tratados como em uma diária costumeira. A equipe técnica deu seu aval de que estava em condições de iniciar a filmagem, os atores do filme foram posicionados e os atores da companhia receberam sinal verde para dar início à representação.

A cena que se segue no filme à atuação da peça, foi realizada também no interior do Teatro Oficina, mas neste caso, adotou-se estratégia oposta. Trata-se de uma cena que reproduz o intervalos da peça, na qual Heitor conhece Júlia. Após o fim da encenação do primeiro ato da peça As Bacantes, o público convidado pela assessoria de imprensa deixou o local, restando apenas os figurantes contratados. Parte destes estão 
posicionados na cena. Para a filmagem desta cena Lina Chamie possuía uma decupagem e marcação dos atores. As equipes técnicas adicionais foram dispensadas, permanecendo apenas as equipes habituais de som e câmera, com a câmera fixada ao steady cam.

As demais cenas chamadas de semi documentais pela realizadora se passam no trânsito de São Paulo. Como não haveria possibilidade de fechamento de ruas para a realização das filmagens, optou-se por filmar inserindo o carro de cena no trânsito real da cidade. $\mathrm{O}$ roteiro impunha que as seqüência fossem filmadas em meio a um trânsito pesado, que justificasse os elementos que aparecem na narrativa. Alguns trajetos foram pré-estabelecidos, mapeando-se as mãos das ruas, os cruzamentos e semáforos.

A câmera em geral era fixa ao vidro do carro por um equipamento especial conhecido como grip $^{195}$ ou era operada pelo operador que ia sentado no banco do carona ou no banco traseiro do carro. Mais uma vez optou-se por não se tentar impor controle às situações que se apresentavam. A câmera muitas vezes era ligada uma única vez durante a tomada, continuava-se filmando sem intervalo entre as tomadas. Parava-se para trocar fitas, ou caso algum problema técnico ocorresse. Quando o posicionamento da câmera e enquadramento permitiam, a diretora ia dentro do carro, acompanhando a ação e enquadramento em um monitor portátil. Em algumas raras vezes, quando não foi possível que Lina fosse dentro do carro com os atores, a câmera ficou ligada durante todo o trajeto, no qual uma ou algumas tomadas, dependendo de suas durações eram registradas. Quando o carro retornava ao ponto inicial, onde se encontrava a equipe, a diretora e os demais técnicos, como diretora de fotografia, por exemplo, revisavam o material captado. O técnico de som ia, em geral no porta malas do carro, ou no banco

195 Equipamento que fixa a câmera por meio de ventosas a superfícies aderentes, como vidro de automóveis, entre outros. 
traseiro, quando o enquadramento permitia. A partir desta avaliação, decidia-se por fazer ou não uma nova rodada de imagens e sons.

Em um atelier ${ }^{196}$ de montagem que Jean-Marie Straub e Danielle Huillet ministraram e no qual compartilharam suas experiências como realizadores, estes falavam a respeito das diversas tomadas registradas de uma cena do filme Ouvrier, Paysans $^{197}$ (2001). Eles afirmavam que era preciso desperdiçar negativo, fazendo tantas tomadas quanto fossem precisas, para que a luz e atores pudessem se encontrar. Esta reflexão, sobre as condições ideais para que a tomada perfeita se realize, reflete as condições sob as quais foram realizadas a maioria das cenas de A Via Láctea. Não se podia ter controle da maioria dos fatores envolvidos, desde condições climáticas, situação do tráfego na cidade e em alguns momentos, a diretora não podia nem mesmo presenciar a atuação do elenco. Era preciso abrir mão do controle da situação e seguir fazendo quantas tomadas se julgasse necessário no momento, até se ter uma falsa certeza de que havia material suficiente para a montagem. Dizemos falsa, pois também as condições de monitoramento nem sempre eram as ideais e Chamie teve de conviver com algumas surpresas na montagem, como a presença de cones colocado pela produção para proteger uma fila de carros que acabou aparecendo onde não deveria. Reveses como estes precisaram ser retocados em pós produção.

Para estas cenas de automóveis em trânsito, se todas as condições podem ser imprevisíveis, a forma como Lina Chamie pensa em seus enquadramentos, no entanto, é bastante planificada. Para A Via Láctea, houve uma preparação intensa por parte da diretora, buscando referências tanto em filmes, como em Making ofs de filmes que tenham tomadas realizadas em automóveis e ambulâncias.

196 Atelier realizado para os alunos do Le Fresnoy, Tourcoing, França, 2002

197 STRAUB, Jean-Marie, HUILLET, Danièlle. Ouvriers, Paysans, Paris, 2001 
E em um segundo momento, Chamie fez estudos com Kátia Coelho, a diretora de fotografia usando-se para isso a câmera com a qual deveria filmar, em situações semelhantes ao que iria vivenciar no filme. Após seus estudos, Lina Chamie repassava a decupagem com a $1^{\mathrm{a}}$ Assistente de Direção, Inês Mulin, desenhando os planos, quando necessário ou posicionando-os em uma planta baixa, dependendo do tipo de cena da qual estavam tratando. A decupagem apontada e um certo controle sobre o número de planos que deveriam ser feitos nas cenas, foi a estratégia de planejamento necessária, para se ter algum parâmetro de previsão das diárias, que contavam com tantos elementos imponderáveis.

Outra estratégia adotada em A Via Láctea diz respeito à linha narrativa. Esta deixa espaço para muitas aberturas em seu entendimento. A construção fragmentada faz com que o filme se reformule a cada plano. De certa forma o final do filme é antecipado nos planos iniciais de Heitor atravessando a rua. E a chave para a compreensão da linguagem empregada no filme também é dada na construção desta primeira sequiência. Mas como veremos, há um jogo de perguntas que nunca são respondidas, senão com outras perguntas, o que leva o espectador a se indagar o tempo todo sobre suas certezas a respeito desta narrativa. Por exemplo, há uma cena no topo do Edifício Martinelli, entre Heitor e Júlia, que figura no filme em dois momentos. Na primeira vez, a cena tem a função de reafirmar o amor entre os personagens, já na segunda, alude-se à separação do casal, dando a entender que a memória do que é vivido, também se transforma à luz de uma percepção presente. Cada nova informação se sobrepõem às existentes, reformulando a concepção que se pode fazer desta linha narrativa. O filme, produto linear é construído a partir de sobreposições de fragmentos temporais, sem que seja dada ao espectador a chave para unificá-los de forma 
cronológica, pois muitas vezes se tratam de possíveis versões para um determinado acontecimento.

Na primeira seqüência do filme, mencionada acima, vemos um homem que atravessa a rua de um lado a outro insistentemente e um tilintar de chaves o acompanha. Ele parece preocupado, mas não sabemos o que o preocupa. Faz este gesto repetidas vezes e alguns elementos sonoros remetem a possíveis desenlaces para este segmento; uma freada brusca de carro, a mesma freada brusca, desta vez seguida de um ruído de batida de automóvel e o tema de Tom \& Jerry ${ }^{198}$ no início. A cena termina com Heitor correndo para dentro de uma garagem e o perdemos de vista devido à diferença de luz nos dois ambientes. Em seguida a câmera está dentro de um carro que passa por esta mesma rua, reconhecemos ao longe Heitor, que anda de um lado para o outro. O carro freia bruscamente com Heitor olhando fixamente para a câmera e entrando novamente na porta da garagem escura. Desta vez o tema musical que acompanha a imagem é o Quarteto de Cordas $n^{\circ} 14$ em Ré menor de Schubert, mais conhecido pelo tema de $A$ Morte e a Donzela, que continua sobre a imagem seguinte, do interior da garagem escura, com um carro em movimento. A câmera vira-se e vemos, desta vez, Heitor ao volante.

A forma como se articula o encadeamento de sons e imagens nas cenas descritas acima não buscam estabelecer uma situação na qual se fornece informações objetivas para o espectador. São colocadas muitas perguntas e estas continuarão não sendo respondidas, mas sim somadas às demais que vão aparecer.

198 HANNA- BARBERA. Tom\&Jerry, MGM, 1940 (primeira aparição) 
A primeira cena do filme se resolve praticamente em uma das últimas cenas, na qual ouve-se o atropelamento do personagem e na cena seguinte ele é visto inerte no interior da ambulância, ao lado de Júlia, que chora segurando sua mão. O que vimos entre a cena inicial e a do atropelamento, quase no final do filme, pode ser interpretado como lembranças, o filme da vida que passa antes do fim, delírios da agonia. Interpretações diversas serão possíveis, segundo cada espectador.

No filme, há um plano chave que mostra como a articulação do tempo espaço neste filme não busca a representação realista. Trata-se de um plano sequiência que se inicia com a personagem Júlia em sua casa e o som de uma campainha. Ela vai atender à porta, entra o personagem Thiago trazendo um buquê de rosas. Ela indica a ele para se sentar e se dirige para a cozinha, onde prepara um café. A câmera a acompanha. Durante sua ação a campainha toca novamente, Júlia se dirige à porta, entra Heitor enfurecido, perguntando por Thiago, ao que Júlia responde surpresa e irritada: "Que Thiago, Heitor?” A câmera não mostra o local onde Thiago havia se sentado, mas pela reação de Heitor, deduzimos que ele não está ali. Surge o primeiro estranhamento da sequiência, mas a esta altura do filme, o espectador já está habituado à forma como as informações se desconstroem ao longo da narrativa. Júlia volta-se para a cozinha, onde ela afirma estar fazendo um chá. O segundo estranhamento nesta cena é em relação ao diálogo entre Júlia e os dois personagens. Thiago quer um café, ela oferece chá. Já Heitor diz preferir um chá e Júlia quer fazer um café. Novamente a campainha toca. Ela se apressa ema atender a porta, Heitor a segue, e insiste para que Heitor não atenda, mas ele se apresa em acompanhá-la. Os dois abrem a porta juntos. É Thiago quem chega com seu buquê de rosas. Ao final, entende-se que esta é mais uma das seqüências de desconstrução da narrativa convencional, um jogo de subversão com o tempo e o 
espaço fílmico. Não há truques, o plano é feito sem corte e o espectador deduz que o ator que entrou primeiro tornou a sair pela mesma porta, enquanto a câmera acompanhava a atriz, mas ele não deixa de ser surpreendido nas duas vezes que a a porta é aberta. O espectador não pode se apoiar em informações que foram dadas, sobre a localização espacial dos personagens. Esta é reformulada com a passagem do tempo nesta seqüência. Chamie não trabalha com a desconstrução do espaço cênico, mas com a sua fluidez, assim como faz com as noções temporais de cronologia, ao longo do filme. Por esta razão, este plano-seqüência torna-se emblemático do filme, que reafirma a cada instante a desconstrução do fio de narrativa linear.

\subsection{3 - A direção de atores e a não utilização de métodos de atuação}

Enquanto a direção de atores em Hotel Atlântico de Suzana Amaral resultou de um processo bastante planejado, a direção de atores em A Via Láctea de Lina Chamie pareceu seguir um caminho muito mais intuitivo do que planificado.

Lina Chamie não segue nenhum método de atuação. Em seu filme A Via Láctea contou com o auxílio do preparador de elenco Christian Duurvoort para a preparação das crianças e Duurvoort ainda participou de alguns ensaios com os atores principais. Mas não acompanhou as filmagens com os mesmos, apenas as filmagens das quais participou o elenco infantil.

A direção de atores a que se propõem é pautada pelo desenho do personagem a partir do que foi condensado na escrita do roteiro e de conversas com os atores. Como a própria diretora assume: "Eu não tenho um método, para mim, o essencial é conhecer o 
ator, estar próxima deles." ${ }^{199}$ Os atores conseguem agir dentro de um diapasão estabelecido, com liberdade para lapidar este personagem.

Marco Ricca, que interpreta Heitor, personagem principal, se viu cativado imediatamente pelo roteiro. Marco Rica apresentava uma carreira com diversos longas metragens, novelas e peças teatrais. Segundo ele descrevia à época, o roteiro trazia um novo desafio à sua carreira de ator, não só por se tratar de um roteiro não linear, mas principalmente, por trazer situações que ele dizia nunca ter vivido em um filme de ficção, como a inserção dos poemas em diálogos do personagem. Logo em um primeiro contato telefônico, que seria apenas uma formalização do desejo de realizarem juntos o filme, ambos se lançaram em uma conversa, já discutindo alguns aspectos deste personagem. De certa forma, o ator encontrava-se bastante intrigado ao tratamento que seria dado às cenas, como o processo seria conduzido e de que forma ele deveria construir seu personagem, a partir de um roteiro como este.

Já Alice Braga, na época, havia participado de apenas dois longas metragens, Cidade de Deus ${ }^{200}$ (2002) de Fernando Meirelles e Cidade Baixa ${ }^{201}$ (2005) de Sérgio Machado, no qual é protagonista e do qual havia saído bastante abalada pelo trabalho de direção de atores imposto por Fátima Toledo. A atriz não teve uma identificação imediata com o roteiro, mas apoiada por seu pai, o produtor Ninho Moraes, que sentiu que o filme poderia trazer uma amadurecimento para sua carreira, acabou aceitando participar de uma reunião com a diretora, na qual foi definida sua participação no longa.

Depois de formalizadas as participações, do casal protagonista, a diretora prosseguiu, fomentando os atores com material para compor seus personagens. Enviou

199 CHAMIE, Lina. Depoimento em 23/o8/2015

200 MEIRELLES, Fernando. Cidade De Deus, 2002

${ }^{201}$ MACHADO, Sérgio. Cidade Baixa, Brasil, 2005 
a cada um deles o que considerava ser a essência de cada personagem, traduzidas em musicas. Para Heitor o primeiro movimento do Quarteto de Cordas $n^{\circ} 14$ em Ré menor de Schubert, mais conhecido pelo tema de A Morte e a Donzela. Para Júlia, o segundo movimento da Sinfonia em Ré menor de Cesar Franck. Estas duas peças musicais aparecem no filme, no que se pode considerar como a apresentação dos personagens.

Tarkovski afirma em seu livro Esculpir o Tempo que o trabalho do diretor em relação a seus atores é "induzir neste o estado de espírito ideal e fazer com que este seja mantido" ${ }^{202}$ Cada diretor procura à sua maneira, comunicar-se com seus atores e para Lina Chamie seus filmes são particularmente imbuídos de música. Esta é uma forma de expressão que permeia toda sua vida, já que antes de se tornar diretora, esta concluiu seus estudos em música, tendo sido clarinetista durante anos. Lina define: "para mim, a música é, muitas vezes, mais clara do que um objeto concreto que está diante dos meus olhos.",203

Lina Chamie deu prosseguimento ao seu trabalho de duas formas: encontrandose de maneira menos formal com seus atores, para conversas e em ensaios, com leituras do roteiro, que se configuraram, muito mais como uma dinâmica de aproximação entre os atores Marco Ricca, Alice Braga e Fernando Alves Pinto, do que propriamente como ponto de partida para elaboração das cenas.

Durante a pré-produção, ainda, Marco Ricca, pediu em uma destas conversas com a diretora, que estes construíssem juntos uma organização linear das cenas do roteiro, que se encadeiam de maneira não cronológica, o que fizeram até certo ponto, pois, como foi dito, o roteiro é construído a partir de camadas de tempo que se somam. Marco Ricca, no entanto, se mostrava, durante a pré- produção, confiante no processo 
que estava se estabelecendo. Marco Ricca possui uma personalidade mais metódica e em seu trabalho como ator, precisa de certezas para poder avançar, pois busca construir para si, um chão sobre o qual o seu personagem pode caminhar.

Lina Chamie aponta, que naquele momento de sua vida e carreira, a atriz Alice Braga era uma atriz muito entregue, muito intuitiva, muito menos técnica do que Marco Ricca, que possuía uma trajetória bastante diversa. Lina Chamie relembra uma das primeiras conversas que teve com a atriz em que perguntava a ela como ela compunha a personagem ao que Alice Braga respondeu: "não tenho a menor idéia"203. Esta conversa com a atriz dá a entender sobre uma não racionalização do processo de criação da personagem. Para Alice, surgiu, durante este processo de criação, a necessidade de perguntar à Lina Chamie quais eram os gostos musicais e literários da personagem, em outras palavras, o que tocava Júlia, o que a fazia se emocionar.

Um dos pontos que fortaleceu a relação de Alice Braga com Júlia, foi a prova de figurinos, na qual teve liberdade para opinar, contribuindo com o trabalho de Marjorie Gueller e Joana Porto. Nota-se que, para alguns atores, partir de dados concretos possui muito mais efeito do que uma digressão sobre o estado de espírito do personagem, ou o que deve ser sua essência. A forma como o personagem se veste, as cores do cenário, os objetos que o cercam em uma cena podem ter muito impacto sobre um ator na criação do universo interno e no seu comportamento.

No entanto, se a descrição do processo de pré-produção de A Via Láctea em relação aos atores parece sucinto é por que de fato foi um período marcado por poucos acontecimentos, dada a pouca disponibilidade dos atores, não foram numerosos os encontros para ensaios. As provas de figurino aconteceram dentro do previsto. Nada que

203 CHAMIE, Lina. Depoimento em 23/o8/2015 
perturbasse uma ordem aparente do desenrolar desta produção foi deflagrado e ao mesmo tempo, podia-se notar um vínculo crescente entre os atores.

Muitas vezes, para diretores e atores, na pré-produção já se delineiam alguns caminhos de como deverá transcorrer as filmagens, como serão compostas as cenas. Surge, muitas vezes a partir dos ensaios todo um desenho de como cada parte do roteiro será filmada e o que os diferentes momentos do filme pede de determinado ator. A préprodução foi um momento de preparação intensa para a diretora, de afinação com sua equipe, de criação do filme a partir do contato e colaboração entre os departamentos, no entanto, a criação com os atores parece ter transcorrido de forma latente.

Tal forma de conduzir a direção de atores nos leva a supor que o processo quando desenvolvido de uma forma intuitiva traz à tona a personalidade de cada ator, mas também deixa mais evidente para o ator qual a tarefa que lhe cabe, ou o trabalho interno ao qual este deverá se dedicar para encontrar seu personagem. Cabe ao ator trilhar este caminho, encontrar o que lhe toca mais profundamente, o que muitas vezes, pode levar o ator a se sentir solitário em sua busca.

Para alguns atores o trabalho pode acontecer de forma racional, para outros, mais provável que aconteça no nível emocional, de conexão com o universo interno de seu personagem. E neste processo o diretor é um guia que traz os parâmetros e observa de fora, rejeitando o que não vem ao encontro do filme e acolhendo e amplificando aquilo que dá forma aos seus conceitos.

Voltando, ainda à reflexão de Tarkovski em Esculpir o Tempo ${ }^{204}$ sobre a direção de atores, ele acredita que o diretor deve ser inventivo na busca da melhor maneira de levar o ator a fazer aquilo que ele deseja, pois cada ator, pede uma maneira de ser

\footnotetext{
204 CHAMIE, Lina. Depoimento em 23/o8/2015
} 
dirigido e ainda um mesmo ator, pode exigir abordagens diferentes, para papéis diferentes. Entretanto, para se entender um ator, muitas vezes é necessário a um diretor percorrer todo o processo de dirigi-lo em um primeiro trabalho, tentando por todos os caminhos, para que, talvez, um dia, se consiga elaborar uma forma eficiente de abordálo. Este modo de trabalho, que dá toda a liberdade para o ator, que pudemos observar em A Via Láctea, pode também ser revelador de conflitos, quando estes existirem.

O primeiro dia de filmagens foi um dos mais conturbados, com a presença de jornalistas no set de filmagens, tendo como ônus não se cumprir o que estava planejado. Resultou em um dia bastante frustrante, permeado por tensões entre direção, equipe e elenco e que teve como decorrência o que viria a se passar no dia seguinte. O segundo dia de filmagem pode ser considerado o momento que definiu como o processo entre direção e elenco iria transcorrer durante o restante do filme.

A ação se passava em uma locação cenografada como a casa de Júlia. Eram cenas idílicas entre o personagem Heitor de Marco Ricca e Júlia de Alice Braga, nas quais se definia o estabelecimento da conexão amorosa entre os dois. Havia no roteiro uma série de referências externas ao espaço da cena que a diretora trazia para o roteiro, um poema, que Heitor declamava para Júlia, uma narração em que Júlia descrevia Heitor, à maneira de documentários sobre animais selvagens e uma dança que Júlia executava diante de Heitor como um contraponto à sua personalidade sisuda.

A cena era extensa e os atores tinham blocos de texto consideráveis, muitos na forma de monólogos e a maneira que Lina Chamie escolheu para filmar estas cenas também acabou por contribuir para que o conflito se instalasse. Em oposição aos momentos em que os personagens estavam no carro sem movimentação, nesta locações, a diretora se decidiu por usar a câmera em steady cam, acompanhando a livre 
movimentação dos atores. Quando se chegou à locação, era o primeiro contato dos atores com aquele espaço. Na pré-produção, esta cena havia sido ensaiada na forma de leituras e conversas, não existia um desenho claro do que a cena seria. Lina possuía a cena pré-decupada em relação à movimentação dos atores, mas que pressupunha variações em função de como os atores iriam transitar pelo local.

Se Lina Chamie tinha a cumplicidade de sua equipe, começou a surgir, neste momento, um embate com seu elenco principal. Marco Ricca e Alice Braga não tinham o texto completamente decorado e as instruções que eram dadas por ela ao operador de câmera em momentos precisos da cena deflagraram um processo de crise. Em decorrência desta situação, as tomadas foram repetidas à exaustão. A esta altura, os dois atores principais haviam se colocado contra sua diretora. Em dado momento da diária, Marco Ricca chegou a se queixar à Inês Mulin, $1^{\mathrm{a}}$ assistente de direção que se sentia abandonado pela diretora. Lina Chamie reflete sobre este momento: "O que o Marco sentiu lá deve ter sido justamente abandono, sendo ele um ator mais técnico e, portanto, acostumado a métodos mais tradicionais. Certamente esta minha falta de método o incomodou, numa cena que ele a priori não compreendia. Acho que até ali ele se sentia dono do processo e, neste dia, veio o abismo do incompreensível."205

A cena foi filmada até o final, porém na montagem, todo o material teve de ser cortado, pois não possuía qualidade suficiente para entrar no filme. Segundo Lina Chamie $^{206}$, não haviam tomadas inteiras que pudessem ser aproveitadas, a dança não continha carisma algum, e estava claro, no material, que os atores não tinha entendido o que a diretora desejava expressar com esta parte do roteiro.

205 CHAMIE, Lina. Mensagem em E-mail à autora em 5/09/2015

206 CHAMIE, Lina. Depoimento em 23/08/2015 
Quanto ao desfecho da diária, culminou em uma discussão acalorada entre atores e diretora, da qual também participou Fernando Alves Pinto, tendendo a defender a diretora, com quem já havia trabalhado antes. A discussão, naquele momento, não trouxe nenhuma revelação sobre o filme, mas deu vazão às angústias e anseios de todos os envolvidos. Lina Chamie considera este momento como um "exercício de exposição de um para com o outro" 207 que teve como conseqüências uma posterior afinação entre ambos

Inês Mulin, em uma conversa com Lina Chamie neste mesmo dia, trouxe a sugestão de que os atores deveriam seguir marcas precisas para que se sentissem "menos soltos" ${ }^{208}$ como ela definia. Lina Chamie define esta sugestao como uma espécie de apoio aos atores, e que entendemos como uma necessidade de limites ou parâmetros que têm alguns atores para poderem se lançar em suas façanhas de atuar.

Inês Mulin ainda sugeriu à Chamie, que quando houvesse dificuldades com o texto da parte dos atores, que se fizesse planos curtos adicionais, dando assim maiores possibilidades de montagem para a cena. Vemos aqui, como uma simples sugestão técnica, criada com o intuito de auxiliar os atores, pode ter interferido no papel criador da diretora, no que se refere à decupagem do filme. Não que a intenção da assistente de direção fosse interferir na elaboração dos planos. Seu objetivo era que filmagem fluísse de maneira mais tranqüila, visto que a repetição excessiva estava, naquele momento, desestabilizado os atores. Com a possibilidade de "picotar" os planos, a diretora se sentiria mais segura em seguir em frente com a cena, no entanto, tendo que para isso, modificar, na montagem, sua decupagem inicial. Esta passagem ilustra o que

207 CHAMIE, Lina. Mensagem em E-mail à autora em 5/o9/2015

208 MULIN, Inês. Conversa durante a filmagem de $A$ Via Láctea em 2005. 
entendemos como o acontecimento, em como os elementos elencados, por vezes não se rearranjam da forma como haviam sido previstos.

Outro elemento que devemos considerar é a rede de criação que o diretor forma com sua equipe e elenco. A rede é necessária para que um certo tipo de produção possa ser colocada em marcha. E o andamento do filme depende do todo. Este é um exemplo muito vivo, em que vemos como alguns departamentos são solicitado para solucionar problemas em outras áreas do filme. Em como a montagem, pode ser afinal um reconciliador do que se desejava fazer no momento da decupagem, da planificação e no momento da filmagem, em que todos os elementos juntos, acima citados, culminam por minar uma seqüência do roteiro.

Ao indagar Lina Chamie sobre a interferência de Inês Mulin, com as sugestões de marcações e decupagem, se estas poderiam ter trazido algum prejuízo ao filme, Chamie afirmou que não, que a sugestão da Assistente de Direção ajudou-a a estabelecer uma linha de ação que foi posta em prática na diária seguinte. E mesmo adotando uma postura mais mecânica na hora de estabelecer as diretrizes das cenas, Lina Chamie conclui sobre este processo que vivenciou: "o caminho da interpretação, se for verdadeiramente percorrido é inevitavelmente solitário, como de fato, na vida, ninguém jamais poderá viver por nós as situações, o que mostra a inutilidade de indicar como sentir (métodos). A emoção é indomável. A jornada é neste sentido abismal. E acho que a Via Láctea tinha muitos destes gestos selvagens, a começar pelas Bacantes e a terminar com a poesia, sempre o sentimos, este filme, como vertiginoso. Além, é claro, de ser um filme sobre a morte, maior mistério, ou mais solitário, acho que não há. Era um filme muito mais assustador do que nós percebíamos ali na hora. "209

209 CHAMIE, Lina. Mensagem em E-mail à autora em 5/09/2015 
A partir do terceiro dia de filmagem, Lina Chamie passou a estabelecer marcações iniciais para as cenas, mas continuou com suas conversas com os atores. Ao longo do filme, o conflito inicial deflagrado com o ator Marco Ricca e no qual foi seguido por Alice Braga, se reverteu. Lina Chamie descreve que sua relação no set de filmagem com Marco Ricca se transformou, a partir deste dia em uma relação com sintonia fina, em que eles precisavam trocar poucas palavras para entender um ao outro. No entanto foi necessário esperar que o filme acabasse e diretora e ator vissem o filmes juntos para que todo mal estar inicial fosse superado e os dois firmassem uma parceria que já rendeu aos dois um segundo filme juntos.

Lina Chamie tece, a propósito da diária em que se situou o conflito com seus atores, uma reflexão a propósito do ato de filmar e em especial sobre esta diária em que o conflito com seus atores eclodiu: "Nós nos preparamos tanto para algo, e depois quando aquilo está acontecendo, muitas vezes não conseguimos ver o que é essencial, o que é invisível, que é apenas sensível e está em questão numa cena, por que estamos cegos, tentando cumprir o que havíamos planejado."210

Se em A Via Láctea havia um planejamento de como lidar com as situações inusitadas que pudessem decorrer das filmagens no corpo a corpo com a cidade, parecia improvável vivenciar uma situação semelhante ao que se passou justamente na filmagem de uma cena na qual se tinha maior controle dos elementos. Tratava-se de uma locação fechada para o filme, nas quais as condições meteorológicas interferiam pouco, com a presença de apenas dois atores.

O processo de A Via Láctea pode tornar mais evidente as interferências dos diversos fatores que compõem uma filmagem. De certa maneira, a reflexão de Lina

210 CHAMIE, Lina. Depoimento em 23/o8/2015 
Chamie dialoga com todos os processos de realização de filmes de ficção e com a frase de Bresson ${ }^{211}$ quando este afirma que ir a uma filmagem é como ir a um encontro, no qual não se pode prever o que será visto. Mas como sugere Bresson ${ }^{212}$, o diretor deve estar sempre em estado de alerta para conseguir acolher o inesperado.

\subsection{4 - Montagem de imagem e som}

Sobre o processo de montagem, houveram algumas contingências que fizeram com que a diretora não acompanhasse o montador em um primeiro momento. Ainda decorrente da decisão de iniciar as filmagens sem ter a totalidade dos recursos para finalizar o filme, Lina Chamie, que também assina a produção do filme, precisou fazer algumas escolhas para que pudesse ter algum planejamento em relação à finalização do filme.

Haveria um edital de finalização do qual o filme poderia participar, desde que fosse apresentado um primeiro corte do filme. No entanto, a data final para entrega do material era muito próxima à data de término das filmagens. Neste caso, durante a montagem, o material em mini dv era copiado para uma fita back up e simultaneamente, começou a ser preparado para montagem, com seu armazenamento em um $H D$. Uma contingência de agenda da montadora prevista para o filme, fez com que se optasse por trabalhar com um outro profissional, não previsto inicialmente, para poder se chegar a um resultado a tempo de garantir a participação no referido edital. $\mathrm{O}$ mesmo foi feito com o material sonoro. As cenas gravadas em película tinham sido reveladas logo após as respectivas diárias e o material digitalizado.

211 BRESSON, Robert. Notes sur le Cinématographe, Paris, Éditions Gallimard, 1988

212 BRESSON, Robert. Notes sur le Cinématographe, Paris, Éditions Gallimard, 1988 
A montagem do filme teve início ainda durante a última semana de filmagem. $\mathrm{O}$ montador começou a trabalhar seqüências isoladas, das quais já possuía o material completo. Nesta etapa, em comum acordo com a diretora, ele seguia a ordem apresentada no roteiro e utilizava os boletins de continuidade para ter informações sobre o que havia se passado na filmagem. Alguns dias após o final da filmagem, o montador já tinha em mãos a totalidade das imagens e sons.

Após o término das filmagens a diretora passou a acompanhar a montagem, mas optou por deixar que o montador partisse de propostas próprias sobre a montagem e então intervinha ou remontava as seqüências quando julgava necessário. Duas razões motivaram esta escolha da diretora; a primeira, aproveitar o que pudesse surgir de melhor da colaboração estabelecida com o montador, a segunda, criar um distanciamento entre o momento em que as imagens foram filmadas e as escolhas que precisariam ser feitas na montagem.

A montagem dos sons indicados no roteiro foi feita junto com a montagem das imagens. Sons adicionais foram gravados de maneira improvisada e outros trechos foram utilizados provisoriamente para que a montagem pudesse caminhar como um todo.

Tendo este primeiro corte sido finalizado, a diretora optou por prosseguir trabalhando com o mesmo montador até maturação do filme e a montadora que havia sido consultada inicialmente, executou apenas a montagem do corte final, junto com a diretora, meses depois, quando o filme já tinha conseguido mais aportes para ser finalizado, como previsto.

Sendo assim, o processo de montagem foi realizado em duas etapas contando com dois montadores diferentes, algo não muito usual no cenário da cinematografia 
brasileira, mas bastante comum em alguns países. Esta segunda montadora, de maneira geral, prefere ter tempos de trabalho, no qual age sozinha e em outros, com a presença do diretor. Este é seu método de trabalho. As sugestões são apresentadas, mas o corte é fechado com o olhar da diretora.

A montagem de imagem e som aparecem articulados em A Via Láctea em uma costura fina de diversos elementos e referências com as quais a diretora trabalha. Estas articulações, como dissemos, são pensadas desde a etapa de escrita do roteiro, tendo sofrido poucas modificações no momento da montagem. Portanto a montagem da imagem é indissociável da montagem do som.

O roteiro de A Via Láctea apresenta indicações de que o filme teria uma utilização muito particular do som, tanto do som diegético, como da utilização de músicas. Além de muito sugestivos em termos de imagens, o roteiro apresenta grande quantidade de intervenções sonoras e já esta etapa do projeto pode-se intuir passagens e ligações entre as cenas que ocorrem através do som, como o caso do sinal ocupado de telefone que se funde com o sinal do aparelho de monitoramento cardíaco no interior da ambulância.

Atentamos também para a utilização que Lina Chamie fez do som do rádio do carro. Em um primeiro momento o rádio apresenta um fragmento de um noticiário sobre o trânsito na cidade e para isso, foi utilizado um trecho de um noticiário real, falando sobre uma vítima de atropelamento na região da Avenida Paulista. Mais adiante, a diretora se apropria deste mesmo tom de noticiário e grava diálogos previamente escritos, com um locutor de rádio. Desta vez, o que temos é o rádio travando um diálogo com Heitor, como se fosse conhecedor das angústias do personagem. 
O tema musical de Tom \& Jerry ${ }^{213}$ também ganha conotações diversas ao longo do filme. Na primeira vez em que é ouvido, está associado à imagem de Heitor andando de um lado para o outro na rua, à procura de seu carro. O tema acompanha a primeira imagem do filme. Já na segunda vez que retorna, o tema está associado à imagem da ambulância que tenta driblar o tráfego de automóveis da cidade. Na terceira vez o tema retorna sobre a imagem de um menino correndo por lugares escuros da cidade e faz a transição para a imagem deste mesmo menino dormindo em uma sala confortável com uma televisão já fora do ar. Trata-se de Heitor, quando criança. Nesta cena, a mãe do menino pergunta o que ele estava assistindo ao que ele responde que era o desenho do Tom \& Jerry ${ }^{214}$. Este tema musical une estes elementos, a princípio díspares no filme e gera associações entre a ambulância, o momento do atropelamento e uma lembrança da infância do personagem, preparando o espectador para o final do filme.

Na cena inicial ouvimos também o som de uma freada de carro acompanhada de uma forte batida sobre a imagem de Heitor que sai de quadro neste momento. Este mesmo som quando reiterado no final, fornece ao espectador o elemento que faltava ao enigma: trata-se do som de Heitor sendo atropelado, naquele momento em que tentava encontrar seu carro. O atropelamento no filme é apenas ouvido, o som de batida se dá sobre uma ponta preta. O que nos faz supor que neste filme, som e imagem possuem igual hierarquia na veiculação das informações.

Os temas musicais, o Quarteto de Cordas em Ré Menor de Schubert para o ator Marco Ricca e a Sinfonia em Ré menor de Cesar Franck para atriz Alice Braga, entregues por Lina Chamie aos atores durante a fase de ensaios também está presente no filme. O tema de Shcubert aparece pontuando algumas sequiências do personagem 
Heitor e o tema de Franck, está presente em uma seqüência à qual a diretora costumava se referir como "Júlia e a Cidade"215. Estas peças servem como um comentário musical, ou a forma como a diretora traduz estes dois personagens.

Estes, entre outros exemplos da trilha sonora do filme, a maneira como estão entremeados às imagens levam à compreensão de que seria impossível chegar a um resultado com a imagem, sem que o som fosse levado em conta. O som, no caso, era um elemento essencial para se determinar os tempos das imagens, o tempo de reação dos personagens, e a duração dos planos. Por esta razão, optou-se em trabalhar com muitos sons adicionais mesmo que de forma provisória durante o momento da montagem.

$\mathrm{Na}$ edição de som estes foram substituídos pelos definitivos e também foram feitas as operações padrão, como acertar ambientes, acrescentar ruídos de sala, corrigir diálogos que estavam incompreensíveis. Mas, grosso modo, a maioria dos sons já possuía um lugar determinado desde o momento em que se fez a montagem de imagem.

A forma entrecortada da narrativa deste filme poderiam dar a entender que este é um filme construído na montagem a exemplos de muitos filmes que haviam sido pensados para um tipo de construção linear e tiveram suas formas subvertidas na montagem. Em A Via Láctea, no entanto, parte-se de um roteiro no qual a narrativa é construída preferencialmente partindo-se de uma associação de elementos ao invés de uma relação de causa e efeito. E estas articulações já estão no roteiro. É uma narrativa na qual os fragmentos se completam e o sentido do filme depende do encadeamento geral das cenas, como é o caso de documentários ou filmes ensaísticos, em que a visão do todo é formada a partir de fragmentos sobre um mesmo tema.

“(...) é o tratamento seqüencial do tempo. Chamo assim o tratamento que constitui a narrativa por blocos desiguais e descontínuos de espaço-tempo, por oposição

215 CHAMIE, Lina. Depoimento durante as filmagens de A Via Láctea, São Paulo, 2005 
ao modelo de representação, que é o da cadeia temporal homogênea de causas e efeitos, de vontades que traduzem em acontecimentos." 216

Jacques Rancière traz em As Distâncias do Cinema uma descrição de uma vertente narrativa que se opõem ao realismo. Esta reflexão é feita a propósito da articulação dos blocos de tempo/espaço nos filme Mouchette ${ }^{217}$ (1967), dirigido por Robert Bresson, mas que no entanto, pode ser aplicada à maneira como o filme $A$ Via Láctea é articulado, de modo que as impressões causadas por cada bloco de cena, que somadas, resultam na grande pintura que é o filme.

Como foi visto, as obras das quais a diretora se serviu para elaborar A Via Láctea, aparecem de maneira fragmentada e muitas vezes destituídas de seu sentido inicial, pois estão a serviço da construção de uma nova semântica. Comparamos a montagem de $A$ Via Láctea com a referência em que Rancière ${ }^{218}$ faz a uma analogia feita por Bresson entre as palavras e os planos; as palavras só fariam sentido quando colocadas ao lado de outras e assim construiriam o sentido da oração.

A Via Láctea, como já vimos, possui uma escrita particular, na qual as aberturas de sentido possuem igual peso que as construções, uma obra que, quando revista, pode gerar ainda novos entendimentos. As articulações, criadas no roteiro e arrematadas na montagem das imagens e sons criam o encadeamento do filme, a forma como este será desfrutado pelo espectador, em toda sua duração. Mas não é apenas a justaposição dos planos que cria um sentido nesta obra, mas sim as diversas associações que podem ser feitas entre estes.

\footnotetext{
216 RANCIÈRE, Jacques. As Distancias do Cinema, Contraponto, Rio de Janeiro, 2012, pg. 56 217 BRESSON, Robert. Mouchette, 1967

218 RANCIÈRE, Jacques. As Distancias do Cinema, Contraponto, Rio de Janeiro, 2012, pg. 64
} 


\section{3. - CONCLUSÃO}

Trazer estes processos criativos à luz significa articular uma série de perguntas para as quais o filme se constitui como resposta. Não necessariamente como resposta definitiva, mas como o filme possível, realizado sob determinadas condições e apenas sob estas condições.

Vimos, como ao longo de todo o processo, estas duas diretoras conseguiram resolver os problemas que se colocaram de antemão e aqueles que surgiram, uma vez que a engrenagem de realização de seus filmes havia sido posta em funcionamento.

Observamos também como se constitui a rede de articulações presentes na realização de um filme e a criação em rede entre os diversos colaboradores do diretor cinematográfico.

As singularidades de cada um dos projetos e as semelhanças que emergiram ao se realizar tais análises apontam para o fato de que os processos de criação serão sempre únicos, mas existe um saber, relativo a um ofício, o ofício do realizador que é acumulado e pode ser transmitido entre os diversos criadores desta área.

O que estas duas obras apresentam como dado mais significativo do trabalho do diretor é que este nunca está inerte. Sua mente está sempre percorrendo o processo de realização, de uma ponta a outra, executando ligações, articulando todos os aspectos que precisam ser agenciados na criação de um filme. 


\section{4. - REFERÊNCIAS BIBLIOGRÁFICAS}

ABIB, Aleksei e CHAMIE, Lina. A Via Láctea, São Paulo - Roteiro Cinematográfico, 2004

ALBÈRA, François. (diréction) Les Formalistes Russes et le cinema - Poétique du Film, Nathan, Paris, 1996

ALIGHIERI, Dante, . A Divina Comédia, tradução de MOURA, Vasco Garça, Landemark, São Paulo, 2011

AMARAL, Suzana. Hotel Atlântico, São Paulo - Roteiro Cinematográfico, 2007

ANDRADE, Carlos Drummond. Reunião, Rio de Janeiro, José Olímpio, 1978, 9ª Edição,pg. 178

AUMONT, Jacques. L'Oeil Interminable, Cinéma et Peinture, Nouvelles Éditions Séguier, Paris, 1995

A Teoria dos Cineastas, Papirus, Campinas, 2004

AVEllar, José Carlos. Cinema e Literatura no Brasil, São Paulo, Câmara Brasileira do Livro, 1994

BACHELARD, Gaston. La Poétique de L'espace, Presse Universitaire de France, Paris, 1957

BAZIN, André. O cinema, ensaios, São Paulo: Brasiliense, 1991

BENJAMIN, Walter. A Tarefa do Tradutor, de Walter Benjamin, quatro traduções para o português, Organização Lúcia Castello Branco, Belo Horizonte, Fale/ UFMG, 2008

BERGSON, Henri. La Pensée et le Mouvant, Paris, PUF, 1938

BERGMAN, Ingmar. Imagens, São Paulo, Martins Fontes, 2001

BLANCHOT, Maurice. L’espace Littéraire, Paris, Éditions Gallimard, 1955

BORDWELL, David. Sobre a História do Estilo Cinematográfico, Campinas, Papirus, 2013 
BRESSON, Robert. Notes sur le Cinématographe, Paris, Éditions Gallimard, 1988 BURCH, Noël. Práxis do Cinema, São Paulo, Perspectiva, 1992

BUÑUEL, Luis. Meu ultimo suspiro, São Paulo, Cosac Naif, 2006

CALVINO, Italo. Seis Propostas para o próximo Milênio, São Paulo, Companhia das Letras, 1990

Os Amores Difíceis, São Paulo, Companhia das Letras, 1996

CAMPBELL, Joseph. O herói de Mil Faces, São Paulo, Pensamento, 2007

CAMPOS, Haroldo. A Arte no Horizonte do Provável, Ed. Perspectiva, $2010-5^{\text {a }}$ edição

CAMPOS, Haroldo e PAZ, Octávio. Transblanco - Em Torno a Blanco de Octávio Paz, Guanabara, São Paulo, 1986

CARRIÈRE, Jean Claude. A linguagem secreta do cinema, Rio de Janeiro, Nova Fronteira, 2006

CHAMIE, Mário. A Quinta Parede, Nova Fronteira, Rio De Janeiro, 1976

CHKLOVSKI, Viktor. Resurrection du Mot et Litérature e Cinématographe, Paris, Éditions Gérard Lebovici, 1985

DELEUZE, Gilles, L’image Mouvement, Paris, Les Éditions de Minuit, 1983

. L’image Temps, Paris, Les Éditions de Minuit, 1985

Bergsonismo, São Paulo, Editora 34, 2012, 2ª edição

DUBOIS, Philipe. Vídeo, Cinema, Godard, São Paulo, Cosac Naif, 2004

DUCHAMP, Marcel. O Ato Criador, in A Nova Arte - Organização Gregory Battock - São Paulo, Editora Perspectiva, 1975

ECO, Umberto. A obra aberta. São Paulo, Perspectiva, 2001

EISEINTEIN, Sergei. A forma do filme. Rio de Janeiro, Jorge Zahar Editor, 1990 
ESPINOSA, Júlio Garcia e outros. Simples Assim, Intermeios, São Paulo, 2012

GODARD, Jean Luc. Jean Luc Godard por Jean Luc Godard, Barcelona, Barral, 1971

HUILLET, Danielle, STRAUB, Jean- Marie. Humiliés, Trézélan, 2003

KANDINSKY, Vassili. De Lo Espiritual En EI Arte, Ediciones Paidós Ibérica, 1996 Punto y Línea Sobre El Plano, Ediciones Paidós Ibérica, 1996

LYNCH, David. Em Águas Profundas, Rio de Janeiro, Gryphus 2008

LUMET, Sidney. Fazendo Filmes, Rio de Janeiro, Rocco, 1998

MARTIN, Marcel. A linguagem cinematográfica. Belo Horizonte, Editora Itatiaia, 1963

MOURLET, Michel. Sur Un Art Ignoré, Cahiers du Cinema, Paris, 1959

MÜLLER, Marcelo. Rodrigo Mingoti, FRANCO, Marília da Silva Estratégias da direção processos de realização em longas metragens brasileiros contemporâneo, Tese de Mestrado - Universidade De São Paulo, Escola de Comunicações e Artes, 2010 MURCH, Walter. In the blink of an eye; a perspective on film editors. Univ. Califórnia Press, 1995

NOLL, João Gilberto. Hotel Atlântico, São Paulo, Francis, 2004

PASSERON, René. Pour une philosophie de la Création, Editions Klincksieck, 1985

PAREYSON, Luigi. Os Problemas da Estetica, São Paulo, Martins Fontes, 1989 - 2a edição

PEIRCE, Charles Sander. Semiótica, São Paulo, Editora Perspectiva, 4a edição - 2012 PLAZA, Júlio. Tradução Intersemiótica, São Paulo, Editora Perspectiva, 1987

RANCIÈRE, Jacques. As Distancias do Cinema, Contraponto, Rio de Janeiro, 2012 A Fábula Cinematográfica, Campina, Papirus, 2013

SALLES, Cecília A. Gesto inacabado - Processo de criação artística, São Paulo, Fapesp/Anabluni, 2004, $3^{\text {a }}$ edição

Redes de Criação, São Paulo, Horizonte, 2006 
TARKOVSKI, Andrei. Esculpir o Tempo, São Paulo, Martins Fontes, 1998

TAVARES, Mónica. Processos de Criação na Arte In: Processos de Criação na Educação e nas Artes, Organização Alberto Roiphe e Sumaya Mattar, São Paulo, Escola de Comunicações e Artes, 2012

O Processo Criativo In: Processos Criativos com os meios eletrônicos,

São Paulo, Hucitec, 1998

VALÉRY, Paul. L'Invention Esthétique, In Oeuvres I, Paris, Gallimard, 1957

Variedades, Iluminuras, São Paulo, 2007

XAVIER, Ismail. O Discurso Cinematográfico: Opacidade e transparência, São Paulo, Paz e Terra, 2005 - $3^{\text {a }}$ edição

A Experiência do Cinema, São Paulo, Graal, 2008 - 4a edição

\section{5. - REFERÊNCIAS AUDIOVISUAIS}

AMARAL, Suzana. A Hora da Estrela, Brasil, 1985

Hotel Atlântico, Brasil, 2009

BARCINSKI, Philippe. Não Por Acaso, Brasil, 2007

BRESSON, Robert. Mouchette, 1967

Tônica Dominante, Brasil, 2000

CHAMIE, Lina. A Via Láctea, São Paulo, Brasil, 2007

DHALIA, Heitor. O Cheiro do Ralo, Brasil, 2006

GONÇALVES, Carolina. Dia de Glória, Brasil, 2002

HANNA- BARBERA. Tom\&Jerry, MGM, 1940 EUA (primeira aparição)

KAR WAI, Wong. In The Mood For Love, Hong-Kong, 2000 
MACHADO, Sérgio. Cidade Baixa, Brasil, 2005

MEIRELLES, Fernando. Cidade De Deus, 2002

NADER, Carlos. O Homem Comum, Brasil, 2014

STRAUB, Jean-Marie, HUILLET, Danièlle. Ouvriers, Paysans, França, 2001

TARKOVSKI, Andrei. A Infância de Ivan, URSS, 1966

O Espelho, URSS, 1979

\section{6. - REFERÊNCIAS TEATRAIS}

EURÍPEDES. As Bacantes, livre adaptação da tragédia de Eurípedes, por José Celso Martinez Correa e a Companhia Teatral Teat(r)o Ofincina Uzyna Uzona -Brasil 1996

\section{6. - REFERÊNCIAS DA INTERNET}

IMDB:

IMDB.com:http://www.imdb.com/title/tto118694/trivia?ref_=tt_trv_trv consultado em 10/10/2015

SINDICINE: http://www.sindicine.com.br/site/profissionais.asp\# 